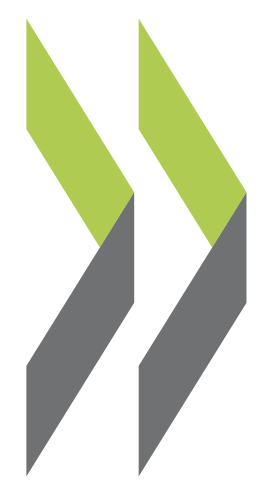

OECD Labour Market and Social Policy Occasional Papers No. 41

\title{
Care Allowances for the Frail Elderly and Their Impact on Women Care-Givers
} Jane Jenson, 
Organisation de Coopération et de Développement Economiques

OLIS : 11-Jul-2000

Organisation for Economic Co-operation and Development

Dist. : 13-Jul-2000

DIRECTORATE FOR EDUCATION, EMPLOYMENT, LABOUR AND SOCIAL AFFAIRS

English text only EMPLOYMENT, LABOUR AND SOCIAL AFFAIRS COMMITTEE

LABOUR MARKET AND SOCIAL POLICY - OCCASIONAL PAPERS NO. 41

CARE ALLOWANCES FOR THE FRAIL ELDERLY AND THEIR IMPACT ON WOMEN CARE-GIVERS

J. Jenson and S. Jacobzone 


\title{
DIRECTORATE FOR EDUCATION, EMPLOYMENT, LABOUR AND SOCIAL AFFAIRS
}

\section{OCCASIONAL PAPERS}

This series is designed to make available to a wider readership selected labour market and social policy studies prepared for use within the OECD. Authorship is usually collective, but principal writers are named. The papers are generally available only in their original language -- English or French -- with a summary in the other.

Comment on the series is welcome, and should be sent to the Directorate for Education, Employment, Labour and Social Affairs, 2, rue André-Pascal, 75775 PARIS CEDEX 16, France. Additional, limited copies are available on request.

The opinions expressed and arguments employed here are the responsibility of the author(s) and do not necessarily reflect those of the OECD, nor those of national correspondents

\section{Applications for permission to reproduce or translate \\ all or part of this material should be made to:}

\author{
Head of Publications Service \\ OECD \\ 2, rue André-Pascal \\ 75775 Paris, CEDEX 16 \\ France
}

Copyright OECD 2000 


\section{FOREWORD AND ACKNOWLEDGEMENTS}

Jane Jenson is a professor at the Université de Montréal and Stephane Jacobzone is a member of the OECD Secretariat. We thank the experts who have collected the information for the national reports which have been synthesised in this report: Australia, Jane Mears, University of Western Sydney; Austria, Andrea Holzmann Jenkins Sozialökonomische Forschungsstelle, Vienna; Canada, Janet Fast, University of Alberta; Finland, Anneli Antonnen, University of Tampere; France, Marie Eve Joel, Université Paris Dauphine, Claude Martin, Ecole Nationale de la Santé Publique; Germany, Ilona Ostner, University of Göttingen, Japan, Keiko Higuchi, Tokyo Kasei University. The results of these national studies were discussed during an expert meeting held at the OECD in 1999. This project began at the OECD while Françoise Coré was a member of the Secretariat under the auspices of the Working Party on the role of women in the economy. We acknowledge her contribution to this study. This work received support from Status of Women Canada. We thank Zeynep Karman from Status of Women Canada for her support. We thank P. Scherer from the OECD for his useful comments. We also thank S. Shahriari for her excellent research assistance, and I. Vallard for her technical help. 


\section{SUMMARY}

1. This report discusses the impact of care allowances on women care-givers. These programmes, involving some payment for care in informal care settings, have recently been introduced in several OECD Member countries. While their primary goal has been to help older persons in need of care, their consequences for the persons providing care also deserve to be analysed. The bulk of informal care is provided by women care-givers. In this respect, long-term care systems involve a partnership between formal care systems, the state, and the family, in order to provide a continuum of care. This also renders the analysis very complex. The main objective of the paper is to answer the question: what is the impact for women care-givers of various models of care allowances for the frail elderly?

2. These care allowances have been primarily instituted to address the needs of older persons for care, as well as to offer some compensation for caring responsibilities. Apart from these initial goals, the paper examines first how these new benefits may represent a shift towards the family in the distribution of social responsibilities between the state, the family and the market. Second, it discusses the consequences of this shift for women. In terms of gender equality, it is important to assess the impact of these benefits on women's opportunity to achieve economic equality. The report analyses the impact of new care benefits on women both as informal and formal care-givers. For each benefit, three questions are asked:

- Who provides care?

- How is it paid?

- How is it used?

3. In order to address those questions, the paper compares benefits and payments for care and other arrangements for informal care in a set of OECD countries, selected because they make such benefits available. The countries are Australia, Austria, Canada, Finland, France, Germany, and Japan. In addition, the report also uses more general sources to give a general context to the results. In answering the questions, the paper examines the impact of the care benefit on women's incentives to undertake caring work, thus affecting the participation in paid formal employment of those of working age. The care benefits fall into two categories, short-term monetary compensation, with a benefit in cash or in kind, and long-term compensation providing access to other derived social rights or support services.

4. The benefits are presented as compensation for the costs incurred in care giving, particularly when compared with a situation without benefit. However, they are sometimes offered at only symbolic levels, and do not appear necessarily to minimise gender-related inequalities. Their welfare-enhancing effects depend on their level. Their effects on women care-givers, and in particular on their participation in paid labour market activities, depend primarily on the level of benefits, as it is this which largely determines the reaction of care-givers to such benefits. However, the modest rates of benefits mean that they are unlikely to have been the main determinant of care provision in the majority of cases: care is provided because of need (and would have been even if no benefits had been paid). It is quite possible that at the margin benefit availability did increase supply, but no empirical estimates of supply elasticity are available. In addition, there may have been some effects on the market for formal care services.

5. Findings from this report suggest that within the global budget devoted to old age care and apart from the short-term monetary compensation, emphasis should be put on supporting caring on the longterm. The most innovative schemes offer longer term compensation, such as pension rights, more possibility to combine care-giving with a flexible participation in paid labour markets, and more respite services in order to facilitate the family member's ability to provide care. 
DEELSA/ELSA/WD(2000)2

\section{RÉSUMÉ}

6. Ce rapport discute de l'impact pour les aidants informels féminins des allocations de soins. Ces programmes qui impliquent des formes de paiement pour les soins dans un contexte de soins informels, ont été récemment introduits dans plusieurs Pays Membres de l'OCDE. Tandis que leur but principal a été d'aider des personnes âgées ayant besoin de soins, leurs conséquences pour les personnes procurant les soins méritent aussi d'être analysées. L'essentiel des soins informels est procuré par des aidants féminins. Dans cette mesure, les systèmes de soins dépendance impliquent des partenariats entre les systèmes de soins formels, l'État et la famille, afin d'offrir un continuum de soins. Ceci rend aussi l'analyse très complexe. L'objectif principal de cette étude est de répondre à la question: quel est l'impact pour les aidants féminins de divers modèles d'allocation de soins pour les personnes âgées dépendantes?

7. Ces allocations de soins compensatrices ont été principalement mises en place pour répondre aux besoins des personnes âgées en termes de soins, mais également pour offrir une compensation pour les responsabilités de soins. A coté de ces objectifs initiaux, l'étude examine premièrement comment ces nouvelles prestations peuvent représenter un tournant vers la famille dans la distribution des responsabilités sociales entre l'État, la famille et le marché. Deuxièmement, l'étude discute les conséquences de ce tournant pour les femmes. En termes d'égalité des sexes, il est important d'évaluer l'impact de ces prestations sur les possibilités qu'ont les femmes de réaliser l'égalité économique. Ce rapport analyse l'impact des nouvelles prestations pour les soins sur les femmes, dans leur rôle d'aidants tant formels qu'informels. Pour chaque prestation, trois questions sont posées:

- Qui procure les soins?

- Comment la prestation est-elle payée?

- Comment la prestation est-elle utilisée?

8. Pour répondre à ces questions, l'étude compare les prestations et les paiements pour les soins et les autres arrangements pour les soins informels dans un ensemble de pays de l'OCDE sélectionnés parce qu'ils offrent ce type de prestation. Ces pays sont l'Australie, l'Autriche, le Canada, la Finlande, la France, l'Allemagne et le Japon. De surcroît, ce rapport utilise aussi des sources plus larges pour situer les résultats dans un cadre général. Dans la réponse aux questions, l'étude examine l'impact des prestations de soins sur les incitations des femmes pour entreprendre un travail de soins, affectant dès lors la participation à l'emploi formel payé des femmes d'âge actif. Les prestations de soins se répartissent en deux catégories, de compensation monétaire de court terme, avec une prestation en espèces ou en nature, et de compensation monétaire de long terme offrant l'accès à des droits sociaux dérivés ou des services de soutien.

9. Les prestations sont présentées comme une compensation pour les coûts encourus dans l'activité de soins, en particulier par comparaison avec une situation sans prestation. Cependant, elles sont parfois offertes à des niveaux qui restent seulement symbolique, et n'apparaissent pas nécessairement minimiser les inégalités liées au sexe. Leurs effets bénéfiques en termes de bien être dépendent de leur niveau. Leurs effets sur les aidants féminins, et en particulier quant à la participation aux activités de marché rémunérées, dépendent principalement de leur niveau, car c'est celui-ci qui détermine largement la réaction des aidants à de telles prestations. Cependant, les niveaux modestes de ces prestations signifient qu'elles ne sont probablement pas les facteurs principaux de l'offre de soins dans la majorité des cas : les soins sont procurés en raison des besoins (et l'auraient été même en l'absence de telles prestations). Il est possible qu'à 
la marge, la disponibilité de la prestation ait accru l'offre, mais aucune estimation empirique de l'élasticité de l'offre n'est disponible. De plus, elles peuvent avoir des effets sur le marché des services formels.

10. Les résultats de ce rapport suggèrent que à l'intérieur du budget d'ensemble consacré aux soins pour la vieillesse, et à côté des compensations monétaires de court terme, l'accent devrait être mis sur le soutien des soins à long terme. Les dispositifs les plus innovants offrent des compensations de long terme, telles que des droits à retraite, plus de possibilités de combiner l'activité de soins avec une participation flexible au marché du travail rémunéré, et des services de répit pour faciliter la capacité du membre de la famille à procurer les soins. 
TABLE OF CONTENTS

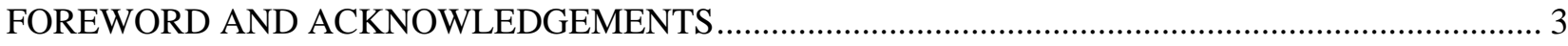

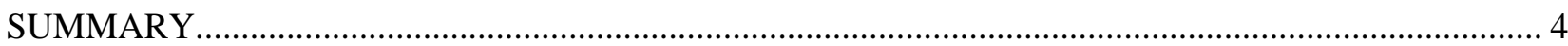

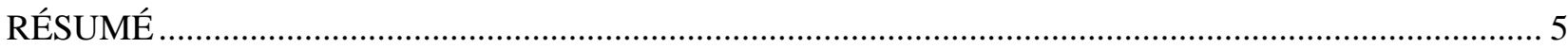

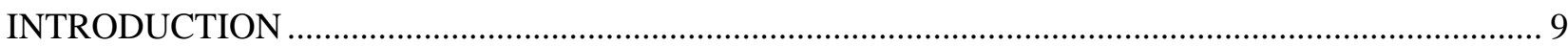

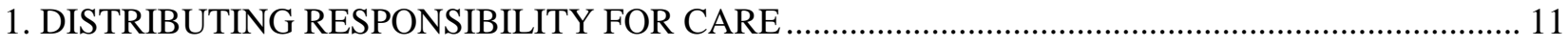

1.1 A new shift in responsibilities between the state, the market and the family............................... 11

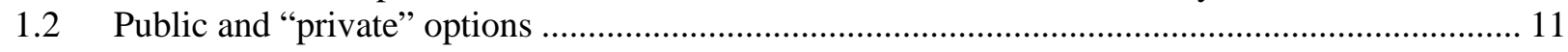

1.3 Gender patterns in labour market participation and informal care work ..................................... 13

1.3.1 Women's participation in the labour market and care-giving activities.................................. 13

1.3.2 Factors influencing participation in the labour market for women care--givers...................... 15

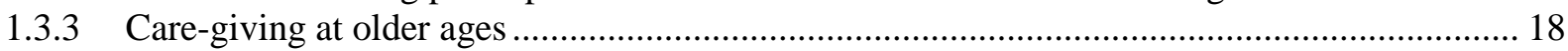

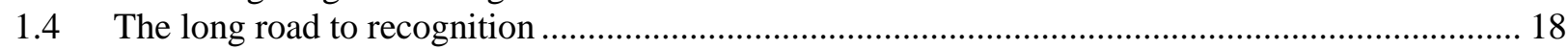

2. CARE SYSTEMS FACING BOTH DEMOGRAPHIC AND SOCIO-ECONOMIC TRANSITIONS .. 19

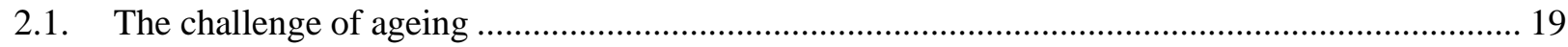

2.2 Social values, social changes and changing policy packages................................................... 20

2.3 Changing housing patterns, from residential care to formally or informally assisted home care .. 20

3. A RANGE OF MODELS FOR CARE ALLOWANCES …................................................................ 22

3.1. Various forms of care allowances, supporting disabled older persons or helping care providers.. 22

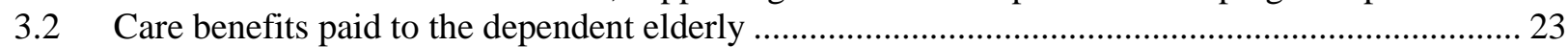

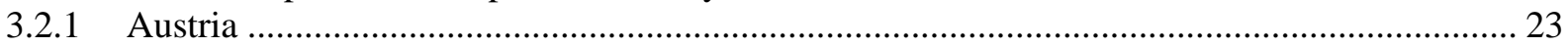

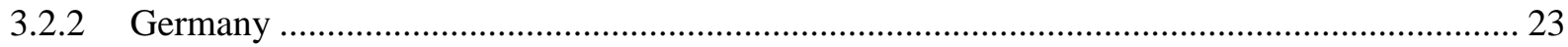

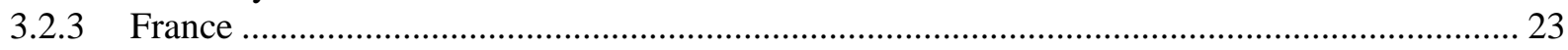

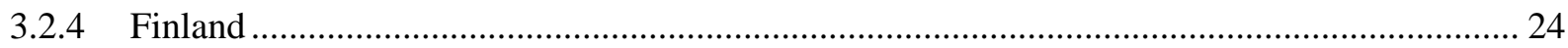

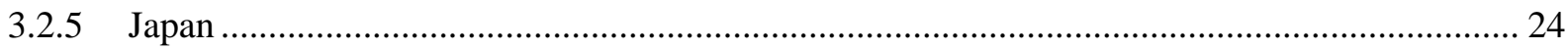

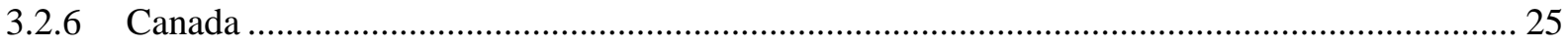

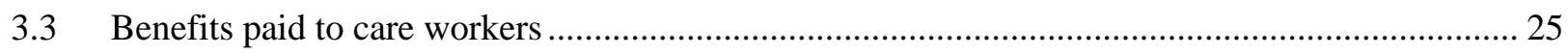

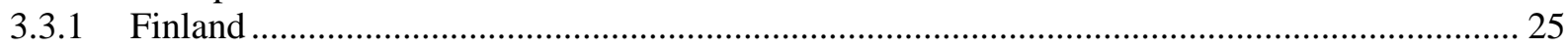

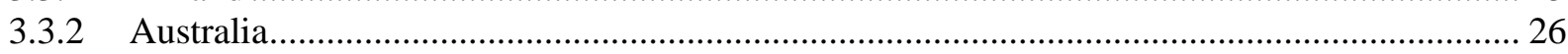

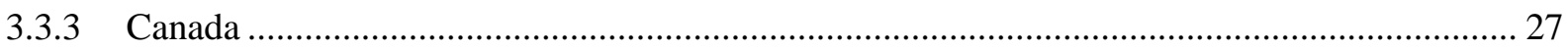

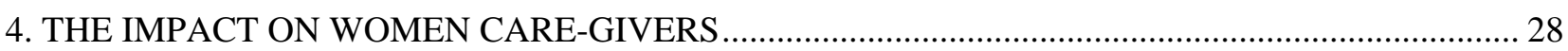

4.1 Who provides care? The consequences for women's labour force participation ......................... 28

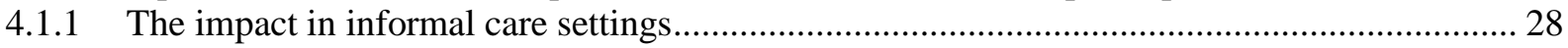

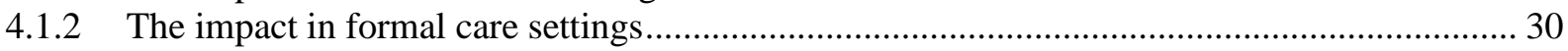

4.2 How is the care benefit paid? And the consequences for women's futures ................................. 31

4.3 How is it used? Benefits in cash or in kind and their consequences for women's incomes........... 32 
4.4 A general perspective on care benefits and care work and their impact on women care-givers.... 33

CONCLUSION: FROM PAYMENT TO RECOGNITION ............................................................... 35

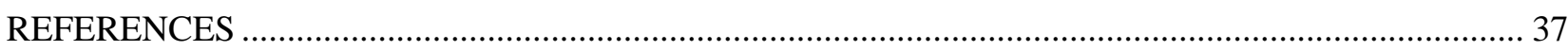

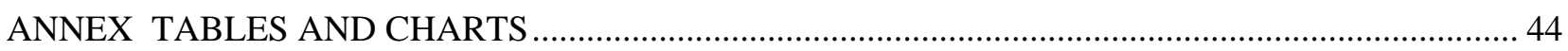

Table 1. Relationship of the care recipient to the informal caregiver ..................................................... 44

Table 2. Formal and legal financial filial obligations for a parent in financial need .............................. 45

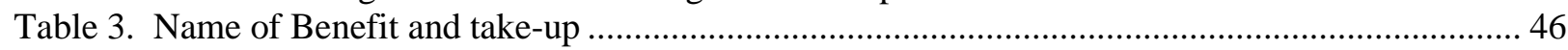

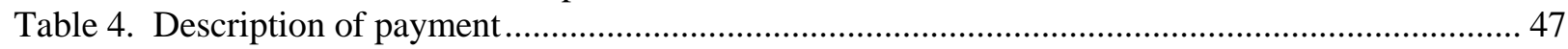

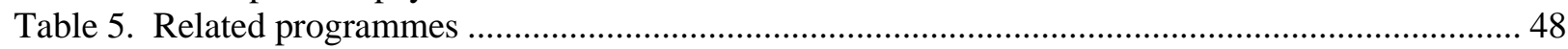

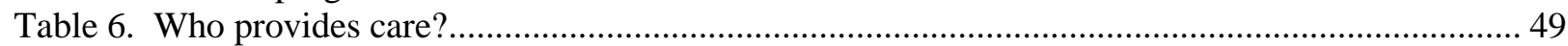

Table 7. Payments for care-givers and labour market participation.................................................50

Table 8. Impact of informal compensated care-giving activities on formal care markets ...................... 51

Table 9. How is it paid? Labour market eligibility rules and amounts ................................................. 52

Table 10. Forms of payment for informal caring work provided by payment for care............................. 53

Table 11. How is it used? Patterns of use of benefits ....................................................................... 54

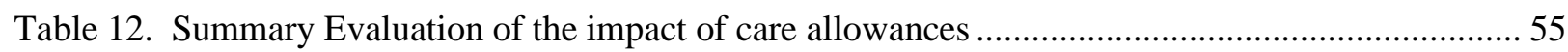

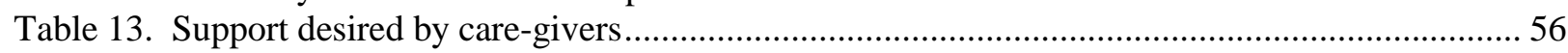

Chart1. Women's participation rates in the labour market by age groups ............................................. 57

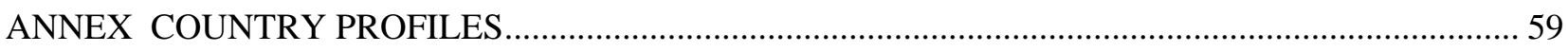

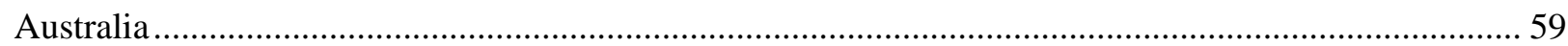

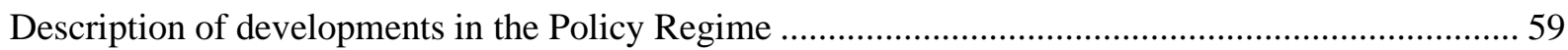

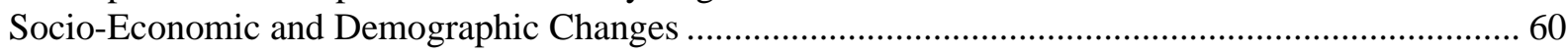

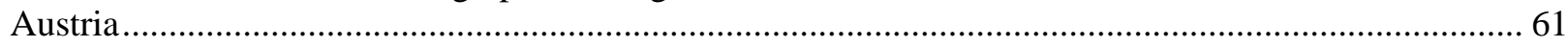

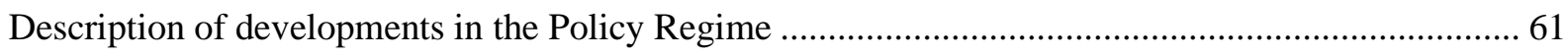

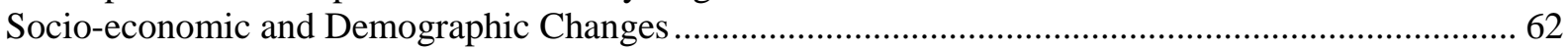

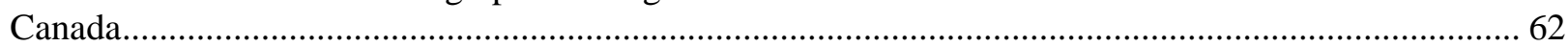

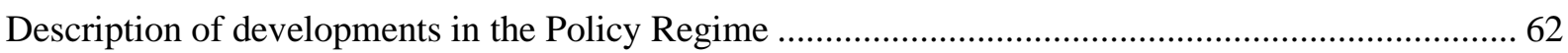

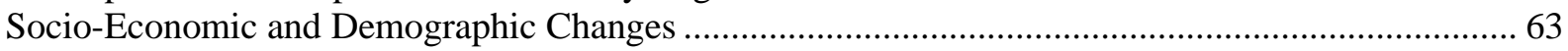

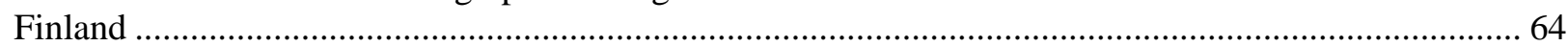

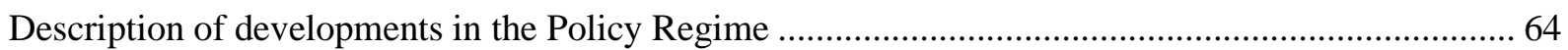

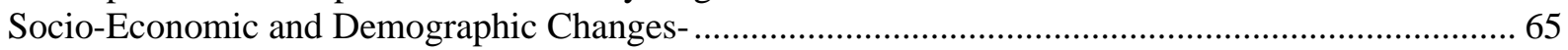

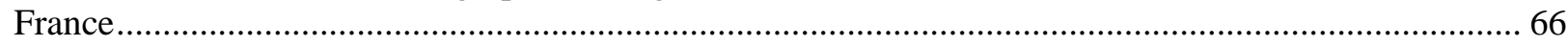

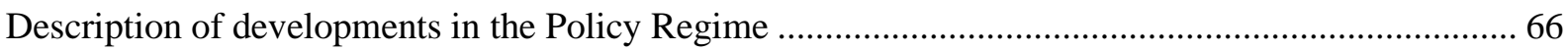

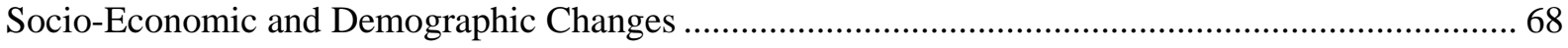

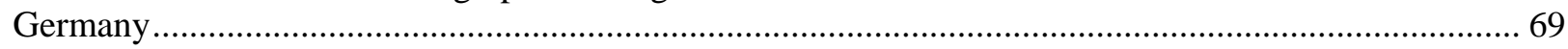

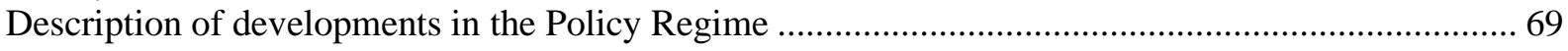

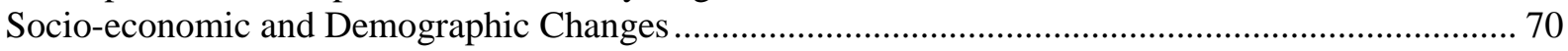

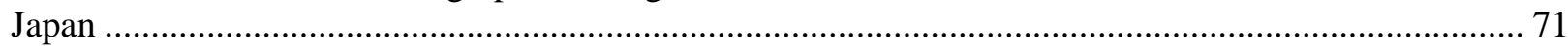

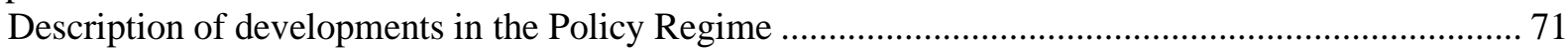

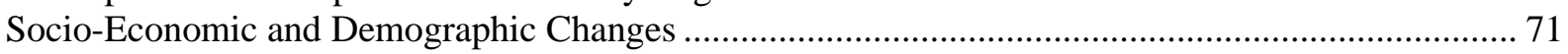

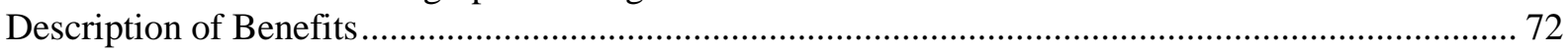




\section{INTRODUCTION}

11. Informal care-giving in a family setting to frail older persons is increasingly an important aspect for family friendly social-policies. The OECD (1997) report Family, Market and Community underlined that "Informal care for disabled or frail elderly people, and particularly more intensive informal care, is predominantly provided by women in all industrialised countries. However the level of public obligation differs quite substantially between countries and has a considerable impact on the resources and rights of those needing care and on the constraints on women as family carers. Yet, the absence of policies or institutional supports for the hidden patient" i.e. the care-givers of older or chronically ill relatives, may have the effect of draining this very resource" (pp. 89)". At the last Meeting of OECD Ministers responsible for social policy held in June 1998, Ministers acknowledged that "Social programmes may need to adapt further so they respond to and support family structures. Women play a special role as formal and informal care-givers".

12. Social policies have had to adapt to the needs generated by ageing, particularly for the care of frail older persons. Public formal long-term care systems are often only the exposed part of the iceberg, as caring systems as a whole involve an important contribution from unpaid caring activities: for most OECD countries, it is estimated that from two thirds up to four fifths of the care is provided by informal caregivers (See Jacobzone 1999). In addition, long-term care policies have been influenced by the demand among older persons for ageing in place, which puts an emphasis on home care and community settings. Financial pressures have also constrained social and long-term care policies. The costs of long-term residential care exceed usually the resources of single individuals and public subsidies are necessary. As a result, institutional care now represents a major financial burden for many countries. Therefore, countries have often implemented deinstitutionalisation policies to address those pressures (Jacobzone 1999). As a result, in a number of countries, declining trends in institutionalisation may have been observed over the recent past, for example in Canada and the United States (Jacobzone et al. 1998).

13. In recent years, as a response to these demographic and social pressures, many countries have begun to institute care allowances or care benefits, available, inter alia, to meet some of the costs of domiciliary care for the frail elderly. In some cases, benefits are paid to the person in need of care while in others benefits are provided to the care-giver. While these programmes were primarily designed to provide help to frail older persons, they will also have a global impact on both informal and formal systems of care. No matter what the design, the addition of payments for care into the mix of services and benefits available to frail older persons will therefore have effects on informal care-givers who provide the bulk of care largely family members-, the vast majority of who are women. These family members can be daughters or daughter-in-law but they can also be the spouses of the older person. Most of these daughters, wives and daughters-in-law are providing "informal" care, that is care outside the market, without monetary remuneration. Without such unpaid work, the situation of the frail elderly would be dire indeed.

14. This report focuses on such payments and their impact on women, both as informal care-givers and as workers in the formal care sector. In order to understand whether these care allowances reinforce or limit existing gender inequalities, three questions will be addressed for each public subsidy or benefit.

- Does the care benefit lead to increased incentives for women to substitute informal caring work for paid employment?

- Does the care benefit provide sufficient compensation for the economic consequences of performing informal caring work and reducing labour market participation? In particular, is the benefit short-term (an immediate monetary exchange), or long-term (by providing access to pension and other social rights)? 
- Does the care benefit alter the structure of the formal labour market for care work?

15. These questions are addressed by comparing new types of benefits and payments for care and other arrangements for informal care in seven OECD countries ${ }^{1}$ : Australia, Austria, Canada, Finland, France, Germany and Japan. For each of these countries information has been collected following an agreed template.

16. The main focus of the paper is not on the advantages or disadvantages of various care benefits for the frail elderly persons themselves. Rather, the paper concentrates exclusively on the impact on women care-givers of providing care allowances and other forms of care benefits. However, for example, between informal care and formal provision of care the choice is an important factor in empowering disabled older persons. This report will emphasise that schemes which encourage such choice also need to take into account its effect on the well-being of those providing the bulk of care in informal settings. Doing so will require that benefits will be evaluated according to their effects on women's opportunity to achieve economic equality and to overcome their disadvantages in the labour force.

17. The main conclusions are that public subsides for home care do not appear to be a tool enhancing greater gender equality. Decisions about payments for care have been made in response to desires to alter the relationships among the four sides of the welfare diamond: state, market, voluntary sector and family ${ }^{2}$. They do not seem however to have either increased the resources for informal care-giving or to have influenced participation in labour markets.

18. The paper first examines the distribution of responsibilities for care between the state, the market and the family, and discusses the factors influencing participation in paid labour markets and in informal care-giving. Second, care benefits are presented in the context of changes such as ageing and changing social values. Third, the paper presents the range of models for care allowances in the countries studied. Finally, it addresses the impact of care allowances on the labour force participation of women care-givers. It also discusses the impact of how the benefits are paid and used on women care-givers incomes and futures and the risk of reinforcing existing patterns of gender inequalities.

1. Such payments are not confined to the seven countries included in this study. For example, some payments for care exist also in the Netherlands. Similarly consumer- directed cash benefits also exist in some US states (Tilly Bechtel 1999) and the federal tax code also include incentives for care-giving. Some states such as California have been paying informal care-givers directly for their services and for a long time (Hendrickson 1988 and Lave 1985 quoted in Ettner 1995). Recently, Ireland introduced a Care Allowance.

2. The notion of "welfare diamond" is adopted from Pijl in Evers, et al. (1994). 
DEELSA/ELSA/WD(2000)2

\section{DISTRIBUTING RESPONSIBILITY FOR CARE}

\subsection{A new shift in responsibilities between the state, the market and the family}

19. All countries are currently discussing and debating how to create an adequate infrastructure to provide long-term care, whether as residential or home care. Approximately one-fifth of the OECD population over 65 is formally in care - one-fifteenth in residential care and two-fifteenths at home. On average, each individual can expect two to four years dependency on formal care at the end of his or her life (Jacobzone 1999). Policy-makers are having to make choices about how to integrate this newly recognised risk into on-going national systems. This involves distributing responsibility for long-term care among the public, private and third sectors as well as the family.

20. Long-term care was originally considered as being a need to be met by families rather than by governments. Therefore, while there has been a move towards public support for care for the frail elderly, most countries insist that public finances bear only a part of the cost. Provision of long-term care continues to be in large part -- if not primarily --the responsibility of families, and to be provided through informal care and unpaid work.

21. Such an assumption about the role of the family immediately raises questions about who will do the work within the family (Stone Kemper 1989). The matter involves empirical and economic questions related to the availability of care-givers and broader issues of justice and equity for women. Women have everywhere been the traditional providers of informal care and are predominant in the formal care activities and the nursing sector (OECD 1998a). However, this gender dimension is frequently overlooked in policy discussions.

\subsection{Public and "private" options}

22. In many countries, local authorities have been at the forefront in pressing for reform. This is due to the fact that the costs of this area of rising demand and social pressures tend to fall on them as providers of last resort. As long-term care was not part of the traditional social insurance systems, it was often provided through social assistance-like arrangements and under the responsibility of local governments. Local agencies were confronted with increasing costs, fragmented programmes, and tendencies to costshift from national programmes to the means-tested assistance, which they administer.

23. Therefore, in some countries, for example Japan, Germany and Austria, local authorities have taken the lead in calling on senior governments to take greater responsibility in this policy area (See Annex, Austria, Germany and Japan country profiles). In the case of Canada, provincial governments have resisted involvement by the central government. In other countries, such as France and Finland, central governments have been handed responsibility for the issue to local authorities. Whatever the pattern, this intergovernmental dynamic was important to all of the cases studied for this project, and helps to account for the great variety of outcomes. The case studies of the project document that the elderly themselves have not been major actors in this process. The political visibility of care-providers often remains limited, although it has increased in some countries. 
24. As noted earlier, decisions about payments for care have been made in response to desires to modify the relationships among state, market, voluntary sector and family. For example, the goal for the Austrian Attendance Allowance is "ensuring autonomy and consumer choice by the long-term care benefit system" (Kalisch et al., 1998). The concerns of OECD's countries about their long-term care system have been focused on the development of home and community care.

25. The 1970s were marked by a movement among health professionals and other experts critical of the institutionalisation of the frail elderly as well as other dependent persons. They promoted community care, in the name of more suitable, desirable and appropriate care arrangements. This perspective led, in some places, to the invention of new housing arrangements and stock, for example, to provide arrangements for assisted living. It also brought about the expansion of formal home care services, ranging from medical services provided at home to help with needs of daily living or housekeeping. Therefore, there had been a determination to demonstrate that community care was more cost-effective than institutionalisation. Home care was viewed as the best solution in both economic and human terms. However, some of the methodological assumptions of the underlying studies can be questioned however (see below and Gramain 1998).

26. In more recent years, pressures in publicly-financed programmes have led to "community care" being promoted as more cost-effective than institutionalisation. Marino et al. (1998) ${ }^{3}$ show that such domiciliary care creates fewer costs on the public side than institutionalisation. Domiciliary care was identified as the best solution, both in economic and quality terms, as this is often preferred by older persons themselves. In many cases, however, this often meant shifting responsibility from the formal sector to a family setting, and the expansion of services for home care needed to meet mounting needs have not always followed the increase in careload.

27. In most countries, when it can be evaluated, the bulk of care is provided in family settings. For example, in Australia, $75 \%$ of community care was reported to be provided informally by family members (Kalisch et al 1998). In Finland, 13\% of home care was reported to be provided by social services (Anttonen 1998), while this percentage was estimated at $10 \%$ in Australia. In France, for all levels of severe dependency, about half of those with a disability receive only informal care, while among those assessed as "moderately" dependent the usage of informal care is two to three times greater than formal service provision (Joël and Martin 1998).

28. More recent studies question implicit assumptions about the costs of such a reliance on community, and especially, informal care (Gramain 1998). They find that reliance on informal care implies:

- significant opportunity cost, borne by the caregiver. This involves:

- the costs of foregone earnings and leisure,

- the displaced expenditure within the household,

- the health effects and the impact on marriages.

- a significant distributional issue in terms of employment, health and future well-being between the sexes, since women are more likely than men to be affected by such policies.

3. A synthesis of these results is also presented in Jacobzone et al. (1998). 
29. As far as the general cost-effectiveness of community care is concerned, recent work (Gramain, 1998) shows that when informal care is valued with an economic equivalent, integrating its implicit value into account, the balance of costs of domiciliary as compared to institutional care are similar. In particular, while community care maintains some cost advantages for the least dependent, institutional care would be more effective for persons at higher levels of dependency, particularly those who are suffering from dementia but remain mobile.

\subsection{Gender patterns in labour market participation and informal care work}

\subsubsection{Women's participation in the labour market and care-giving activities}

\subsubsection{An overview of women's participation in paid labour markets}

30. Women's participation rates in the labour market are shown in chart 1. In all the countries in the study, such participation has been increasing, at all ages. Significant increases have occurred between 1980 and 1998 in Germany in all the middle range age groups, between 30 and 54 years. These rates have also increased in France, Japan and Australia. In Finland, as in all the Nordic countries, these rates have traditionally been high and have remained so. Comparable trends are observed for countries beyond the focus of this study: Belgium, Italy, Luxembourg, the Netherlands, Spain, the United Kingdom and the United States. However in Denmark, France, Italy and Finland, due to pressures in the labour market and other economic incentives, participation rates have fallen slightly since 1980 for those 60 and over. More refined analyses would make the distinction by full or part time participation, and also investigate relative wages. From the perspective of informal care-giving however, participation in the labour market in itself is a key criteria, as it will involve conflicting needs and a higher pressure on women's time resources.

\section{Chart 1. Women's participation rates in the labour market by age groups}

31. The participation curve for women across age groups is therefore becoming closer to the participation for men, with higher levels in the middle of the age span, and lower rates both at the beginning and at the end of the working life. In many countries, participation rates are now significant between 50 to 60, and are still in the range of $10 \%$ above age 60 . This translates into non-negligible potential opportunity costs when disabled or frail older persons of the family need care. In addition, women in these middle/older age groups also often have the burden of helping groups in younger generations with delayed independent living due to difficulties in labour markets (Esping-Andersen, Saraceno 1997).

\subsubsection{The gender distribution of responsibilities in care-giving}

32. In addition to their increasing commitment to the paid labour market, women are still overrepresented in most of care-giving activities. One of the legacies of formal post- 1945 social policies is the existence of an "invisible welfare state" (Waerness and Ringen, 1987) of informal care provided by women to children or the frail elderly. The rapidly rising rates of female labour force participation since the 1960s which were mentioned above have by any means not eliminated this invisible welfare state. Another important aspect is the fact that older persons receiving care are for the majority of them women, and that they often prefer to receive care from another women.

33. Statistics for any type of "caring" reveal that women do more caring work, but that men also take on such responsibilities. The gender difference in Japan results in a huge gap - 85\% of family care-givers 
are female (Higuchi 1998). Information available for other countries reveals gender gaps as well. In Germany, $73 \%$ of informal primary care-givers are female (Ostner 1998). The Canadian and Australian figures report less of a gender gap. In Australia, 56\% of all carers are women (Mears 1998) and in Canada the rate is one point lower (Fast 1998). Nonetheless, a closer look at some of these cases reveals more complex gender patterns behind these simple statistics.

34. First, the gender difference appears even greater when measuring the relative responsibilities assumed in care-giving. A 1995 survey asked a sample of Japanese married women and men caring for and nursing their parents to describe their own level of responsibility and how it was shared with their spouse. Whereas $66 \%$ of daughters and daughters-in-law said that they "do it mostly", only 5\% of men reported they had primary responsibility for parental care. There were also discrepancies between women and men's perceptions of sharing. Only 9\% of women reported doing "half" the work, whereas $43 \%$ of men considered they did "half". A further $33 \%$ of husbands volunteered that they did such work only "when asked to do so". Thus, even when men do undertake the labour of caring, women retain primary responsibility and men are more likely to cast themselves in the role of "assistant".

35. Second, a closer investigation reveals also a clear gender pattern in the type of tasks performed by men and women: women often take responsibility for the tasks involving personal care and emotional support, which may result into a greater burden of caring. The 1996 General Social Survey carried out by Statistics Canada asked about the kinds of tasks undertaken by care-givers. Here important gender differences are again to be observed. Women care-givers were much more likely than were men to be involved in personal care (34\% to $18 \%$ ), emotional support (33\% to $23 \%$ ), meal preparation ( $40 \%$ to $19 \%$ ) and housekeeping (36\% to $15 \%$ ). All of these are regular, repetitive tasks that are needed almost daily. In contrast, men were more likely than women to undertake home maintenance tasks (43\% to $19 \%$ ). In other categories, such as transportation, bills and banking, shopping or general monitoring of the situation of the elderly person, the gender gap was under $8 \%$, and sometimes negligible. Similar patterns were observed in the Austrian survey of recipients of an Attendance Allowance discussed in more detail below. In Australia, $70 \%$ of primary carers were women, according to recent results (ABS 1999).

36. All of these studies confirm that women provide greater amounts of informal caring work, both qualitatively and quantitatively. Statistics simply reporting the gender of care-givers can sometimes disguise this distributional difference in workload. For example, of all care-givers in Australia, only 56\% are women, but fully $70 \%$ of primary care-givers, that is those with the major responsibility for a dependent person, are female (Mears 1998). In Canada, women have a higher rate for performing all care tasks than men, with the one exception of home maintenance.

37. The result of such gender patterns is that many care providers are sandwiched between paid work and care work, between caring for children and caring for their frail elderly relatives (Rosenthal, 1997). As Table 1 shows, in Canada, Finland and France, over 50\% of the frail elderly receive care from adult children or grandchildren. In Australia, a quarter of all carers are adult children. In Austria, 32\% of those caring for a recipient of an Attendance Allowance are adult children, with children-in-law providing another $10 \%$. In Germany $22 \%$ of care for dependent persons is provided by adult children, with a further $7 \%$ of daughters-in-law doing the work, while in Japan the corresponding figures are $28 \%$ and $21 \%$. In Japan daughters-in-law are carers as frequently as are daughters, which means that some women may be caring for two sets of parents simultaneously. This pattern which is observed for the countries included in the study would easily extent to other countries as well ${ }^{4}$.

Table 1. Relationship of the care recipient to the informal caregiver

4. For example, Lamura et al. (1998) present similar results for Italy. 
38. Given this intergenerational pattern, women in particular are confronted with a situation in which caring responsibilities compete with their own employment and the related accumulation of social rights, such as pension rights and sometimes job-related basic or supplemental health insurance or disability insurance. This conflict will have consequences for participation in the labour force, either in terms of withdrawal/participation, reduced hours and also reduced wages, which will be analysed below. The discussion for older care-givers, mostly spouses but also daughters in some cases, will be undertaken separately.

\subsubsection{Factors influencing participation in the labour market for women care--givers}

\subsubsection{A framework of analysis}

39. As for the general effects of caring responsibilities on labour market participation by care-givers ${ }^{5}$, a standard framework of analysis representing individual decisions regarding labour supply suggests that there are two possibly conflicting effects (Pencavel, Killingsworth Heckman 1986):

- a substitution effect - time needs for informal care work reduces labour market participation, via either full withdrawal or reduction of hours worked.

- an income effect - the high costs of providing for a dependent elderly person may induce those responsible to increase their labour market participation so as to earn sufficient income to compensate the costs.

40. These two possible effects provide no single a priori outcome for care-givers, even if it may be hypothesised that the substitution effect may be stronger than the income effect in many cases. In addition to this standard framework, the literature on care-giving (Carmichael and Charles, 1998) points to two additional effects:

- a demand for respite work. Participation in the labour market might be seen as a way of obtaining respite from the heavy caring work and the associated mental pressure. This could stimulate an increased demand for part-time work.

- a depressing effect on wages for those who do continue to undertake paid work. People who care have been found to be at a disadvantage on the labour market, because of a high-rate of absenteeism, difficulty in attending training sessions, and the necessity to be confined to less rewarding job which can be combined with care-giving responsibilities. This depressing effect on wages has often been reported also for child care activities (Fuchs 1990).

41. These effects are important for analysing the consequences of the main labour market implications. Later sections of the report explore the impact of payments for care for the countries included in the study in light of these possible effects.

\subsubsection{Empirical results in the international published literature}

42. There is a significant literature of the impact of care-giving on labour market participation decisions $^{6}$. The empirical results mainly originate from countries other than those involved in this study,

5. The particular effects of care benefits will be analysed later in the paper. 
but are of general relevance. A significant survey is also available in a recent publication by Statistics Canada (Keating, Fast, Frederick, Cranswick, and Perrier 1999). Earlier descriptive results, which are mentioned in this survey, had hypothesised an impact of marital status, which was, however, not confirmed by later results. Descriptive results (Soldo Myllyluoma 1983) had also shown that competing demands on care-givers, including employment, were also among the reasons for exhaustion which could disrupt the care-giving relationship. Brody Schoonover (1986) found that employed daughters provided significantly fewer hours of personal care and meal preparation. Among more recent descriptive results Penrod et al. (1995) find that primary care-givers who do not work in the paid labour force provide more hours of care per week than those who are employed.

43. The first empirical results with some econometric control come from US data from the early 1980s: Muurinen (1986) concluded that primary care-givers of terminally ill patients in a hospice setting suffered a considerable loss of earnings because of withdrawal from the labour market or reduced hours of work. This effect increased with age for women. In addition, of the care-givers who continued in paid employment during the informal care episode, $60 \%$ reported losses of income because of care-related increased absenteeism from work. Results from Stone and Short (1990) use the first U.S. National Informal Caregiver Survey, linked to the 1982 wave of the National Long-term care survey (NLTCS). They show that primary care-givers and those caring for elders with greater care needs are more likely to take unpaid leave, reduce work hours or rearrange their work schedules to assume elder care responsibilities. These effects are increased for women, and also persons in fair to poor health. When predicting the employment of a caregiver, they found some evidence that demands of care-giving might keep some people from work entirely. Younger and more educated care-givers had a higher probability of being employed. They also found evidence of self-selection among care-givers, which should be considered when forecasting changes in care-giving costs associated with labour force participation or specific policy shifts.

44. The intensity of care-giving seems to be a key factor in explaining the possibility of work accommodation. The econometric results displayed by Boaz and Muller (1992) show that results differ for full-time and part time work, using the same National Informal Caregiver survey linked to the 1982 wave of the U.S. National Long-Term Care Survey. Estimating a simultaneous decision model, they find that full-time employment by care-givers reduces the time they allocate to providing unpaid help by 20 hours a week and that female care-givers were much less likely than their male counterparts to have full time jobs. However, part-time employment by care-givers has no statistically significant effect on care-giving (and light care-giving does not have a significant effect on part-time participation in the labour market. Additional results make use of the 1989 National informal Caregiver survey linked to the 1989 wave of the National Long-Term Care Survey (Boaz 1996). This enables the observation of trends over time, as full time employment for women rose in the United States in this period. The results show that full time employment reduces caregiving time substantially. The effect of full-time employment on informal caregiving by primary care-givers of ADL-disabled elderly did not change during the 1990s, care continued to be maintained for heavy activities such as bathing and dressing. One may conclude from these results that while the rise in full time employment does not necessarily reduce the availability of caregiving, it may have substantially increased strains for women engaged in these two competing demanding activities.

6. In addition, the recent results from the 1996 US AARP National Alliance for Care-giving national survey of caregivers, are in line with the findings presented in this section. American Association of Retired Persons, Public Policy Institute, women and long-term care, Fact Sheet number 77. In particular, they found that four-fifths of care-givers were women, that 19 percent provide at least 40 hours of car per week, and that among the caregivers who provide more than 40 hours of care per week, 31 percent report physical or mental health problems. 
45. More refined results for the opportunity cost of elder care take into account intra-family decisions, involving the characteristics of the children, using exogenous characteristics such as gender, and also endogenous ones such as co-residence or health. Wolf and Soldo (1994) use the US National Survey of Families and Household (NSFH) and analyse the implications of care-giving for married women. With a milder definition of care-giving ${ }^{7}$, they find fewer effects on labour market decisions. Stern (1995) uses the National Long-Term Care Survey and controls for the endogeneity of some child characteristics, show that there are large effects of parent marital status and distance. Ettner (1995) uses data from the 1984-1988 US Survey of Income and Program Participation (SIPP) restricted to females and shows that co-residence with a disabled parent leads to a large, significant reduction in work hours for female children, due primarily to withdrawal from the labour force. Ettner (1996)a is able to control for some endogeneity bias using the 1987 National Survey of Families and Households. The first results, assuming that care-giving is exogenous, suggest that care-giving for parents living outside the household decreases work by 0.15 hour per week for men and 2.14 hours per week for women. After correcting for endogeneity, these results confirm the gender difference but also point to co-residence as a key factor: co-resident care-givers are much more likely to reduce hours work,

46. In general, most of the literature suggests that the main effects of informal caring work are to reduce the number of hours worked rather than labour market participation itself, at least for all but the most intensive forms of caregiving. The most recent UK study (Carmichael and Charles 1998) shows that when care-giving is moderate (less than 20 hours a week), labour market participation increases while participation for those with heavy caring responsibilities (more than 20 hours a week) is only slightly reduced. For care-givers with heavy responsibilities - that is, more than 20 hours a week of care work these data show that both the number of hours worked and hourly wages are reduced. The reduction of income is $17 \%$. Most of the most recent US data suggests that women would not tend to choose between work and caregiving but would try to rearrange their job schedule to accommodate both.

47. To sum up, to the extent that trade-offs must be made between caring for a family member and labour force participation, the following factors have to be taken into account:

- the intensity of care-giving,

- whether the care-giver resides with the person needing help,

- whether paid work is part time or full time.

48. When very intense care-giving must be provided, and when no formal care alternatives are available, and even more so when this is done by children residing with their parent, there are clear detrimental effects of care-giving on labour market outcomes. This may clearly represent a threat for women's economic equality and autonomy. At lower levels of care needs, it seems that care-giving does not necessarily reduce participation in the labour market, but it may reduce hours worked (and also, implicitly earnings). Some of these studies also show detrimental effects on the health of care-givers, which are confirmed by numerous qualitative surveys. In other cases the general wellbeing of the woman is put at risk. In addition to these human and psychological difficulties, financial factors may also play a role in family decisions. In the case of institutionalisation, when home care is not possible, Kniesner et al (1999) observed that nursing home entry forced daughters to increase their participation in labour market by $20 \%$, at the same time that additional caring responsibilities associated with the parent's stay in institutional care were created. The authors (1998) estimate that the total welfare loss associated with entry into a nursing home is about three times the direct cost of the nursing home itself, which itself is high.

7. Any point in time during the last 12 months. 


\subsubsection{Empirical qualitative results from the materials produced in the OECD study}

49. The data available for the countries considered in this report confirm these patterns. Care-givers tend to be employed part-time more than full time, and female care-givers tend to be employed part-time more than male care-givers. For example, in Australia $41 \%$ of primary care-givers participate in the labour market, and $49 \%$ of those are employed part-time. Only $18 \%$ of daughters and $2 \%$ of wives considered that their labour market participation was "unaffected" by caring responsibilities, while $22 \%$ of the former and $35 \%$ of the second group were "excluded" workers (Mears 1998).

50. In Canada, among those caring for frail elderly persons for less than 7.5 hours a week, $64 \%$ of women and $79 \%$ of men are employed full-time. However, of those doing caring work for more than 7.5 hours a week, only $54 \%$ of women are in the labour force (71\% of men). Also, at all levels of caring, $66 \%$ of women care-givers are employed part-time (Fast 1998).

51. Care-givers also report effects on career advancement. Among the whole group of care-givers for the frail elderly, $17 \%$ reported that their considered their job performance was affected by caring responsibilities, $18 \%$ changed their hours of work, $36 \%$ had to come late to work or leave early, and so on. Austrian data show that the amount of caring work has a clear effect on employment. Of those doing caring work for less than 13 hours a week, only $16 \%$ of women are employed part-time but the rate doubles for those caring 13 hours or more (Holzman Jenkins 1998).

\subsubsection{Care-giving at older ages}

52. In addition to labour market pressures, care-giving may also be provided by persons who themselves are elderly - that is, the "third age" caring for persons of the "fourth age". There the competing demands are primarily those of the health of the care-givers themselves. . Indeed, older women represent another category very much affected by the fact that so much care of the dependent elderly is done informally by elderly partners, siblings or friends. While in most cases care-givers are likely to be middleaged adult children, a significant number of older adults hold caring responsibilities, often for a partner. A majority of care-givers are older than 50 in Finland, France and Japan. In Austria, 37\% of those caring for a recipient of an Attendance Allowance are over 60 and almost one in five is older than 70. Japan also has $22 \%$ of care-givers over 70. More than a quarter of care-givers are older than 65 in Australia, while in Finland a third have reached that age.

\subsection{The long road to recognition}

53. Such patterns as presented above mean that the rising number of elderly persons in OECD countries will provoke a series of complex challenges to past practices and demand innovative solutions from social and long-term care systems. In particular, the challenge to achieving gender equity and equal opportunities, arising from the traditional distribution of responsibility for caring for frail elderly family members, can be as large - and as complicated - as are the gender issues surrounding childcare.

54. Yet despite the fact that care for the frail elderly depends upon longstanding practices in the gender division of labour and that the design of care benefits can potentially have major consequences for women's chances of achieving equality, the "challenge of the ageing society" is rarely analysed in these terms. ${ }^{8}$ A great more is known about the demographic, economic and health dimensions of the frail elderly

8. $\quad$ For an example, see Jenson (1997). 
than about the situations and needs of care workers ${ }^{9}$ and care-givers, especially those who are providing informal care to 4 of every 5 elderly persons.

55. Elder care policies are far from having been fully developed in the light of equal opportunities or mainstreaming gender issues, as has been the case with child care in many OECD countries. . The goals for such policies remain as stated in the OECD (1994) report on Women and Structural Change: "Fundamental adjustment is required to solve the current contradictions generated by the social contract. This means enhancing compatibility between domestic and employment responsibilities both on a daily basis and across the lifecycle, and developing a new institutional and social framework that reflects the changing labour force profiles and supports equal choices for men and women to combine employment with family responsibilities"

\section{CARE SYSTEMS FACING BOTH DEMOGRAPHIC AND SOCIO-ECONOMIC TRANSITIONS}

\subsection{The challenge of ageing}

56. As discussed in the OECD (1998) report Maintaining Prosperity in an Ageing Society, all of the countries of the OECD face the challenge of ageing populations. All also face the question of how best to provide care for elderly persons who may be more frail than sick, more in need of help with everyday living than of medical care, more in need of help in living autonomously than requiring care in institutions.

57. These issues bridge the traditional divisions between health, social and employment policy. Sometimes the issue is described as a health matter, as when ageing in the community supported by some formal home care is termed more desirable than residential care. But achieving this goal also requires social services and adequate networks for providing care. Sometimes the issue is a social policy matter, when the extra costs of dependency and disability threaten the income security of the frail elderly or their families, while doing informal care may interfere with the capacity of care-givers to earn income and their present or future income security. Sometimes the issue can be analysed as one of employment policy, with attention to mechanisms, which allow care-givers to reconcile informal care work and paid work, or to move in and out of the labour market.

58. This horizontal nature of long-term care needs creates a real policy challenge, as policies are often fragmented around a set of distinctive goals, and with different institutions, or different levels of government, in charge of the various aspects. This basket of needs for long-term care means that there is no clear "policy location" for the problem. Not only does it cross policy domains, but also responsibility for service delivery is shared by a variety of agencies, both public and private, as well as with the market. Finally, the fourth leg of the "welfare diamond" - the family - also has a crucial role to play. This complexity is only now being addressed by policy communities.

9. Christopherson (1997) look at paid workers in the areas of elderly and child care. 


\subsection{Social values, social changes and changing policy packages}

59. In the past, and particularly during the three decades after 1945, the frail elderly and their longterm care needs were not at the centre of thinking about public services and welfare state -- except perhaps in the Nordic countries, where initially institutionalisation policies were implemented early on. Most care was provided invisibly by the women of the family. The social rights of citizenship, whether on an insurance or universal basis, rarely included full access to long-term care. As mentioned, the Nordic countries and some others were something of an exception here: institutionalised care was provided as a social citizenship right (Anttonen 1998, Sipilä Anttonnen, 1994, Christopherson 1997). Elsewhere, any services available were most frequently privately provided, by charitable or religious bodies. Even services that had public support were mostly provided in a social assistance framework, in kind rather than cash, made on a residual basis to those who lack family support and had little income. This involved attaching stigma to an individual or family who had inadequate resources - personal or financial - to cope with their own problems (OECD 1996).

60. Use of such services, whether provided for by the state or private agencies, often "involved some loss of personal status". In Germany for example, the situation before 1995 is described by Ostner (1998) as one in which public benefits, provided by local governments were a last resort. Citizens in need of longterm care had either to turn to their families for care or to pay for it out of pocket. In the latter case, even the better-off and their children were frequently impoverished. Nor is Germany alone in maintaining an intergenerational requirement of support by descendants. Austria, France and Japan do the same (see Table 2).

\section{Table 2. Formal and legal financial filial obligations for a parent in financial need}

61. In recent decades, however, the situation has begun to change. Concerns about the high costs of long-term care have led all governments to search for less expensive solutions, particularly involving home care and community care. Thus, there have been four identifiable sectoral responses (OECD 1996):

- Development of alternative institutions for long-term nursing and the expansion of visiting nursing.

- Expansion of home care services and neighbourhood services, for the elderly and those who care for them.

- Development of a housing stock more suited to the needs of less autonomous elderly persons.

- Provision of cash supports and other benefits to the dependent elderly or to those who do caring work on an "informal" basis.

62. Moreover, there is a clear tendency to define the issue less in either/or terms. No longer is the care of the frail elderly provided either informally at home or in a residential institution. Over the last two decades, the pattern has been one of mixing, so that public services or publicly financed services are made available in a variable package (Evers Svetlik, 1993).

\subsection{Changing housing patterns, from residential care to formally or informally assisted home care}

63. Residential care remains important. Nonetheless, it used by very few elderly persons, both because they themselves wish to stay in their homes and communities and because it is very expensive. For 
example in France 94\% of persons aged 65 and over, including 57\% of those with a serious disability, live in a private home (Jacobzone 1999). In Canada the comparable figure is $93 \%$ and is usually above $90 \%$, and close to $95 \%$ for the countries being studied. However, these statistical picture has to be considered with caution: the boundaries between residential settings and home-like settings have tended to fade, as alternative types of housing have emerged, particularly in Nordic countries care (Szehebely 1999). Often the proportion of elderly persons living with their families has declined, although it remains very predominant in Asian countries -- for example in Japan, where half of the elderly still live with their offspring.

64. While some countries have experienced falling rates of institutional living, this means also that home care setting have had to adapt to coping with higher levels of disability (Jacobzone et al. 1999). In addition, in spite of falling rates in severe disability in private households, at lower levels rates of disability have been more stable. Most qualitative evidence points to the fact that in many cases, the formal part of services which aid the growing number of elderly people with mild disability has had difficulties to cope with rising demands, so that informal care remains today the most important form of care.

65. Although general co-residence rates between parents and children have decreased, care-givers still tend to live with the elderly person. In Australia, for example, three of every four primary care-givers of frail elderly persons were a family member living in the same household. This proportion is also surely very high in Japan, as the general co-residence rate is highest in Japan among OECD countries with data available. This is despite the fact, moreover, that surveys find, repeatedly, that one of the greatest fears of the elderly is that they will be a burden on their families (for France, Pitrou, 1997, Joël and Martin, 1998).

66. This paper concentrates on the fourth type of change listed above, the payment of care benefits, because it marks a significant change in the way that informal care is conceptualised. This introduces market forces into the informal care system. Sometimes cash transfers go to the frail elderly, money that they may spend or use to "reimburse" their informal care-givers. Sometimes cash transfers go directly to the care-givers themselves. Such newly monetarised relations blur clear distinctions between market and non-market, formal and informal, and paid and unpaid work.

67. Paying care benefits of either kind also immediately raise all the standard and familiar questions about the intersection between employment and work within the family, and about gender relations in the labour market and in the home. 


\section{A RANGE OF MODELS FOR CARE ALLOWANCES}

\subsection{Various forms of care allowances, supporting disabled older persons or helping care providers}

68. While there has been a good deal of movement within the ranks of the OECD countries over the past years, and several have established care benefits, the characteristics of the benefits have varied significantly. The country profiles in annex offer an overview of policy developments in each country, drawing on the materials gathered for this project by country experts. Some benefits have, for example, developed more in response to the needs and preferences of the disabled. Movements of younger disabled persons have worked hard to win attendance allowances. This category is sometimes termed "selfmanaged care" as it developed in the independent living movement for disabled persons. It can also be labelled "consumer directed cash benefit". These have also been made available to elderly citizens in Austria, Germany, France and Finland. In Austria, Germany and France the primary target group is the frail elderly. A recent report funded by the European Commission acknowledges the importance of direct payments to enhance the independence of disabled and older service users. This report is based on material gathered by the National Centre for Independent Living in London, the European Network for Independent Living in Stockholm and Age Concern in the United Kingdom (European Social Network 1999). Consumer-directed long-term care also plays an important role in the US debate (Tilly, Bectel 1999), which has spurred on international analysis in this framework (Tilly, Wiener and Evans Cuellar 2000). Canada in contrast, provides only indirect benefits to the elderly, in kind or through the tax system. The various forms of benefits, with their rate of take-up are described in Table 3.

\section{Table 3. Name of benefit and take up}

69. The focal point of another type of care benefit has been the needs of care providers, leading to the introduction of care allowances. These are offered to some care providers in Finland and Australia. Again, Canada provides care allowances primarily indirectly, through the tax system. As of yet, Japan does not pay care benefits, but there is intense public debate in which both attendance allowances and care allowances are promoted by different groups. (See Annex, also Masamura Higuchi 1996, Higuchi 1998a, 1998b, 1999).

70. A more precise description of payments is provided in Table 4, with the stated goals of the policy, as expressed in country's public debates. Table 5 provides an overview of related programmes which have a similar financial impact by reimbursing home nursing or offering tax credits. Table 5 also analyses the relation of the care benefit to the health system.

\section{Table 4. Description of payment}

Table 5. Related programmes 


\subsection{Care benefits paid to the dependent elderly}

71. In this section, the benefits will be analysed country by country; tables 3 to 5 provide a general overview.

\subsubsection{Austria}

72. Until the 1990s, Austria had a fragmented regime for long-term care, providing very limited residential care, access to which varied by province and by previous employment. The bulk of care for the dependent elderly was provided unobtrusively by informal care-givers who were mainly women. In 1993 a countrywide scheme was created with a federal law, providing for an Attendance Allowance (Austrian Federal Ministry of Labour Health and Social Affairs 1994, Austrian Federal Ministry of Labour, Health and Social Affairs 1998). This programme provides a basic monthly payment, set according to the assessed level of dependency. The recipient has complete control over its use. It may be used to hire an attendant, including family members, or it may be saved or used otherwise. There are no restrictions on attendants' labour force participation, while those who care for very frail elderly persons may easily opt into a pension insurance system.

73. The Attendance Allowance is not means-tested, is available for any condition producing reduced personal autonomy, and is financed out of the tax system. It is meant only to cover partial costs, with the rest coming from out-of-pocket or from social assistance. The programme was explicitly structured so as to increase reliance on home care. Another goal was to focus the incentives towards reliance on family-based home care, as revealed by the lack of restrictions on how it is spent.

\subsubsection{Germany}

74. In the Federal Republic of Germany the risk of long-term care until the 1990s was covered by a means-tested social assistance programme of last resort, and was a local government responsibility. Just as in Austria, local authorities found it increasingly difficult to meet the rising level of demand, and they turned to the central government to take responsibility for care for the frail elderly. The response was the 1995 Care Insurance Act (Alber 1996, Schneider 1999). It is a compulsory insurance regime that provides basic benefits to those in need of care, as assessed by an expert team including doctors, nurses and social workers. The characterisation of need is based on a three-level typology, with a flat-rate grant provided at each level. It may be used in conjunction with personal resources or social assistance. Benefits may be taken in cash or in services. The incentive structure of the programme is to increase reliance on home care and informal care. The recipient has full control over its disbursement.

\subsubsection{France}

75. After several years of experimentation with allowances to the frail elderly, France finally instituted a countrywide programme, although delivered by the regions, in $1997 .^{10}$ The Prestation spécifique dépendance (PSD) is a means-tested benefit paid to any one older than 60 and living legally in France (Joel and Martin 1998). The law neither defines disability in any detail nor establishes any subcategories within it: these are defined by decrees issued by the government. In general, however, after

10. Prior to the reform, a general benefit, designed for handicapped persons, was used for long-term care. (Allocation Compensatrice pour Tierce Personne, ACTP). The general disability benefits (Allocation Adulte Handicappé AAH, are not available above a certain age, and are intended as a minimum income replacement). 
evaluation by a medical and social team, a care plan involving a public benefit under this scheme is offered only to the least autonomous elderly persons, those either confined to bed or a wheelchair, or with reduced mental capacities or only partial mobility. As in Germany, the French benefit can be used either for residential care or care at home. In the case of the former, it is paid directly to the institution. In the case of the latter, the recipient may contract for home care services, hire a personal attendant, or both. Family members, except spouses, may be hired, on condition that they are unemployed. The use of the same benefit for both types of care limits, in other words, the incentives for family-based care. On the other hand, given that the levels of payment are rather low, far from fully matching the needs, there are still incentives to rely on informal networks for care. Home nursing is covered by sickness funds under the general health insurance scheme.

76. Another French particularity is that not only is the benefit means-tested for the recipient but the family and heirs' resources are also included in the calculations. While family members are not required to care in kind or in cash for their elderly (non obligation alimentaire immédiate), the costs of care to the public purse may be deducted from the client's estate. For example, if the estate is greater than 300,000 francs and the beneficiary has used the PSD to hire a daughter (or other heir), the amount of that salary will be deducted from the estate before the remainder is distributed among all the heirs. This creates a very specific internal care family market!

\subsubsection{Finland}

77. One of Finland's two main benefits is a Pensioner's Care Allowance, paid to disabled or frail pensioners. A part of the national age pension system, it was introduced in 1963. Its goal was to allow frail or disabled elderly to remain in their homes; the amount of benefit depends on the level of dependency. It can be used for home care services. There are no restrictions on its use, it is need-tested but not meanstested (Anttonen 1998, Vaarama Kautto 1997).

\subsubsection{Japan}

78. The Public Long-term Care Act passed in Japan in 1997 and due to be implemented in 2000, has been the subject of intense public debate. The country faces a dramatic increase in the elderly population: it is the first country in the world to have $20 \%$ of the population over 65 , and life expectancy, particularly at age 65, is among the highest, if not the highest in the world. In addition, an important share of the elderly requiring care, when they are not in family settings, are institutionalised in medical settings or general hospitals, due to the lack of appropriate residential care facilities. This results in a costly accommodation where unnecessary medical care may be provided resulting in additional heath care expenditure. In addition, the pressure on the informal care system is higher than in other countries due to the fact, that close to half of the elderly reside with their children. This is combined with strong cultural expectations for women to perform care-giving activities.

79. Japan already provides an indirect benefit, via a tax credit for caring for someone over 70 (Twigg, 1996), but it was felt that this was insufficient to address the needs created both by the ageing and social pressures. A first strategy to address some of these socio-economic changes was devised at the beginning of the 1990s within the "Gold Plan", which was oriented to improving provision of appropriate non-acute institutional care and home care. The 1997 Act marks a clear shift in Japan long-term care policy and follows the German example. This Act was intended to address the long-term care needs by creating a new insurance system to cover the costs of long-term care, whether residential or domiciliary. As of now, the law provides only for services in kind, available to frail elderly persons insured under the Act. 
By covering home care as well as residential care, incentives to continue to rely on informal provision are now financial rather than simply cultural.

80. Municipal authorities play an important role in the public debate (Higuchi 1998). Some of them were not in favour of the act (Kazunori 1995) and they are now advocating for the inclusion of cash payments to care-givers. These are seen as being less costly and complicated to provide than the services which would have to be created to meet the services promised under the new legislation. There are also important differences within the country. On the one hand, wealthier metropolitan areas and their local authorities seem to be in a position to meet the requirements of the act, and provide the services. On the other hand, in poorer and older rural areas, particularly in the mountains, local authorities often feel they lack the human and financial infrastructure to implement the structures, which are involved in the Act. As it now stands, the Act provides neither cash benefits nor sufficient support to care-givers, who are often the wives of eldest sons made responsible for their in-laws' care under the traditional rules of the Japanese family. This situation is felt to leave a serious gap in the eyes of some Japanese experts (Higuchi 1998).

\subsubsection{Canada}

81. Most public subsidies for home care going to the frail elderly in Canada provided by the Federal government are indirect ones, delivered through the tax system as deductions or tax credits. Most of these are intended to provide tax relief to disabled adult Canadians no matter their age, but they can be accessed by frail elderly who incur certain medical expenses, under the Medical Expenses Tax Credit, or expenses for ordinary living under the Disability Tax Credit and Attendant Allowance. While the elderly person is normally the one claiming these non-refundable tax credits, "unused portions" may be transferred to a spouse or supporting relative, or the care-giver may be the original claimant. These options obviously blur the distinction, which has been developed here between attendant and care allowances. At the federal level, some direct care benefits are also available for veterans.

82. At the provincial level, in New Brunswick the Department of Health and Community Services has a programme which provides clients with sufficient monies to hire an independent care provider: family members may not be hired, but neighbours or friends may be. In Quebec, and primarily in rural areas not well stocked with public services, the frail elderly may be granted an allowance which permits them to purchase certain homemaking and personal care services or respite care. This is a very limited option in an overall package which still puts the accent on publicly co-ordinated care, via the community health care agency, the CLSC (Centre local des services communautaires).

\subsection{Benefits paid to care workers}

\subsubsection{Finland}

83. The welfare state in Finland had, as did the other Nordic countries, a strong tradition of treating placement in residential care as a citizenship right (Sipilä and Anttonen, 1994). Thus, high quality and nonstigmatised services developed in the first decades after 1945, while adult children have had no financial liability for their parents since 1970. Nonetheless, an interest in providing more flexible care, allowing elderly people to "age in place", generated a parallel system of home-helpers and other professionals delivering a range of services to dependent elderly in their homes. The Finnish system soon became one that provided a mix of residential and home care, with a substantial public involvement in delivery of both.

84. The 1980s, however, also brought a mounting call for support and compensation for those who care for their elderly kin. Initially introduced piecemeal, as part of the existing regime for home help 
services, an increasing number of local authorities instituted home care allowances (HCA). Then, with the reform to the Social Services Act that came into effect in 1993, HCAs (now called Informal Carer's Allowance) were included as a new social care service across the country. The goal is to allow frail elderly to live at home as long as possible. Delivered by municipalities, allowances are granted on the basis of the elderly person's needs, in accordance with a service plan drawn up by the municipality and the care-giver. The benefit is paid, however, directly to the person doing the caring work. Moreover, reflecting the intention to address the needs of care-providers, and to formalise their "informal work", care-givers gained pension rights through the Municipal Pension Institutions and a certain right to respite care.

\subsubsection{Australia}

85. Australia has one of the longest traditions of paying for caring work by family members (domiciliary nursing care). After the Second World War, as did most other countries, Australia emphasised either family care, for the vast bulk of elderly, or residential care for those unable to stay with their families. Then, in the late 1960s there was a shift to funding for home care services in the community. In the late 1980s and the beginning of the 1990s, there was a clear trend towards de-institutionalisation, within the Age Care Reform Strategy. The Home and Community Care (HACC) Programme, initiated in 1985, aims explicitly to maintain people in their homes and shift expenditures to community care, and it recognises the roles of care-givers, by providing support for respite care, information, advice and support. A mid-term review of this programme was performed in 1991 (Commonwealth Department of Health, Housing and Community Services 1991, 1993). By the late 1990s not only was community care much preferred by government to residential care but also introduction of user fees for many services was further shifting incentive structures towards family-provided care (Halton 1998). The HACC programme is a joint commonwealth/state cost-shared program with the federal Commonwealth government providing $60 \%$ of funds, and the States and Territories providing $40 \%$. Since the inception of the HACC programme, the federal government has remained strongly committed to ensuring continued growth of the HACC programme and changing the balance of care towards community care.

86. Two allowances now exist for care-givers in Australia. One is the Carer Allowance, successor to the Domiciliary Nursing Care Benefit (introduced in 1973) and the Child Disability Allowance. This benefit has been established in order to allow for the payment of a small cash benefit to family members who supported a person requiring chronic nursing care at home. It is a cash benefit paid to family members who provide care in the home to an elderly person requiring intensive care who would otherwise be eligible for admission to a nursing home. It is intended as a partial compensation for the costs of caring and is neither income nor assets tested. Although (unlike almost all other Australian cash benefits) it is free of income and assets tests and is not-taxable, the eligibility requirement of providing full-time care generally makes it almost impossible to combine the benefit with paid work, however. Moreover, it is paid at a relatively low rate, (one-fifth of the single rate age pension) which in turn is $25 \%$ of average weekly fulltime earnings. Carer Allowance introduced on 1 July 1999 is an income supplement available to people who care for, and live with, a family member who has a disability. The arrangements differ depending on whether the care receiver is a child (ie, aged less than 16 years) or an adult (ie, aged 16 years or older). (Mears 1998).

87. The second is the Carer Payment, which is a means-tested non-contributory income support payable to an individual responsible for the daily care of a highly dependent person. The level of benefit is the same as the retirement pension (Age pension) and (as is the case with all public pension benefits in Australia) is not much more than the unemployment benefit. The programme was renamed in 1996. Previously it had been called a Carer Pension, and the renaming was intended to signal that caring is work. It is designed to provide income support for people unable to maintain paid employment because they have full-time caring responsibilities. Therefore, people receiving the Payment must meet the pensioner means 
test, cannot be engaged in paid or voluntary work for more than 20 hours a week. When people reach the Age Pension eligibility age, they have the choice of being transferred to the Age Pension or to remain on the Carer Payment. Recepients of the Carer Pension can also receive the Carer Allowance if the person for whom they are caring needs particularly intensive care.

\subsubsection{Canada}

88. As with benefits to frail elderly persons, Canada delivers its support for care-givers primarily through the tax system rather than by direct benefits. As described above, tax relief can be claimed for medical expenses, attendant allowances, and general infirmity or disability. In addition, the Federal government announced a very limited Caregiver Tax Credit in 1998. It is an income-restricted nonrefundable tax credit, which would reduce federal income tax by a maximum of $\$ 400$ a year for individuals residing with and providing in-home care for an infirm dependent relative over 65 . It is available to a caregiver with a net income less than $\$ 13,853^{11}$. The same Budget also announced a sales tax exemption for respite care expenses, which have the effect of reducing the costs to care-givers by approximately $15 \%$.

89. Several exceptions to the indirect form of delivery do exist, however in some provinces. Quebec provides up to $\$ 600$ a year for care-givers to purchase respite care, without restriction on whom they hire. Between 1984 and 1994 Nova Scotia had a Home Life Support programme to compensate family caregivers of the frail elderly. To be eligible, both the elderly person and the caregiver had to have an income that did not exceed roughly the poverty line. The programme was suspended in 1994, following reorganisation of government services, and is unlikely to be resurrected in the near future.

11. The maximum of $\$ 400$ goes only to those whose income is below $\$ 11,500$ and disappears all together at $\$ 13,853$. 


\section{THE IMPACT ON WOMEN CARE-GIVERS}

90. This section will use a typology to help overcome the diversity of particular national situations and to provide an understanding of the impact of such care benefits on women care-givers. The goal of this exercise in classification is to draw some more systematic conclusions about the consequences of the caring benefits for women care-givers. This follows a detailed review of the various types of care benefits available in the seven countries studied, in which care benefits have only been distinguished by type of recipient, disabled older person or care-giver. The typology is derived from Jenson (1997) ${ }^{12}$ and is structured along three main questions:

- Who provides care?

- How is it paid?

- How is it used?

These three questions will be systematically examined in the sections below.

\subsection{Who provides care? The consequences for women's labour force participation}

\subsubsection{The impact in informal care settings}

91. As mentioned in section 1, the overwhelming amount of caring work is still being done by women in family settings (Table 6). Thus, the review of the new care allowance put into place since the 1980s, shows that any change has been at the margin rather than marking a fundamental shift in responsibility. In no case, even those providing the most generous benefits, is informal care eliminated or even substantially reduced. This was also certainly not the intention of these subsidies. As noted in section 1, approximately two-thirds to three-quarters of care for the frail elderly is informal. A great deal of supplementary care, or care going far beyond the hours scheduled by social services, are still provided informally even when a generous payment for care exists (Holzman Jenkins 1998). An evaluation of the now defunct Nova Scotia carer allowance found that women providing care were also working very long hours. In the best of cases the payment for care does no more than cover the most basic needs of the elderly person or the care-giver.

\section{Table 6. Who provides care?}

92. If the recipients of payments for care are being considered, (Table 6), it appears that the responsibility for care work seems to belong even more to women than the general patterns reported in Section 1. In part the reason for the high rate of feminisation of payments for care lies with the on-going and traditional practices of informal care, which involves a self-selection process in the take up of benefit.

12. For a discussion, see Commaille and Martin (1998). 
In each of the countries examined in which an Attendance Allowance or a Caregiver Payment is available, the recipients are overwhelmingly female.

93. However, in Australia, $40 \%$ of recipients are men. This relatively high percentage is due to the design of the social security system, in regard to eligibility for pensions. Those eligible for the Carer Payment are people of working age: the Carer Payment is used by men who have not yet reached retirement age and are caring for a family member. Many women carers would not be eligible if their husbands were working. In addition, many of those who would be eligible for the Carer Payment who are over 60-65 years are on the age pension instead (Mears 1998).

94. In addition, the employment generated, in the case of France, and the new professional qualification created, in the case of Germany, have both reinforced existing patterns. Therefore, $99 \%$ of the persons employed in Frances under the programmes to promote personal services and family-based care (emplois familiaux) are women (Joel and Martin 1998). In Germany, fully 97\% of those who have registered under the new job category of Informal Caregiver are women, a rate which is even higher than the four-fifths observed in Finland, where Informal Carer is also a recognised employment status (Ostner 1998, Anttonen 1998).

95. The relationship between Payments for Care - whether Attendance Allowances or Caregiver Allowances - and labour force participation are complicated (Table 7). The Austrian case was the only one that have been in place sufficiently long to generate data and had an extensive evaluation available ${ }^{13}$. The results from this evaluation show that even non-means tested benefits, which approach a basic income level, do not seem to provide much incentive to modify labour force behaviour. The programme does not prohibit labour force participation. Nonetheless, the Austrian survey found that half of the persons caring for someone receiving an Attendance Allowance were in full-time paid employment separate from their role as carers. However, $26 \%$ of them reported giving up their job or reducing their hours of employment. Indeed, the major factor affecting labour force participation seems to be the amount of care required rather than the payment, as well as the age of the care-givers. This is broadly consistent with published econometric results, mainly based on US data (see section 1). In Austria, only $9 \%$ of the respondents agreed with the statement: "The Attendance Allowance has relieved my financial situation in a way I can afford to give up my job". However the percentage goes up to $29 \%$ for those caring for some one with the highest care needs (Holzman Jenkins 1998).

\section{Table 7. Payments for care-givers and labour market participation}

96. In Finland, where the programme has been in place longer, it seems that non-participation in the labour force and receipt of an Informal Care Allowance go hand-in-hand. Only 16\% of recipients of an ICA were labour force participants (20\% were retired). However, these care-givers may be relatively older (Anttonen 1998). In neither case, however, does there seem to be much sign of an incentive to change labour force participation associated with the Payment for Care. Rather, each appears to provide some, though limited, recognition of work that is already being done and to provide partial support for it. Thus, the Canadian Care-giver Tax Credit of $\$ 400$ dollars per year should be classified in the same category as these other allowances, providing some recognition, rather than an incentive to change from employment to caring work, or anything approaching a labour market wage.

13. An assessment has also been recently made in Germany (Bundesministerium für Arbeit und Sozialordnung, 1998). 


\subsubsection{The impact in formal care settings}

97. Apart from informal care settings, it is also important to consider the impact on the formal care sector. Formal care work is a highly feminised sector of the labour force (see OECD 1998a, the nursing chapter 5, the nursing profession, and chapter 6, carers). The introduction of these payments for care have consequences, therefore, for women already employed as care-givers, whether in institutions or as home care providers. As Table 8 shows, the effects are mixed.

\section{Table 8. Impact of informal compensated care-giving activities on formal care markets}

98. Most studies report that such payments are not directly in competition with formal services. The pattern is generally one of mixed consumption (see also section 4.3). Formal care is still widely used, as is the need for traditional medical services, whether provided at home or not (see also table 5). For example, in Finland dependent elderly persons may receive both the ICA, which goes to their informal care-giver, and the Pensioners' Allowance, which can be used to purchase formal services. Nonetheless, when the HCA first emerged in parallel to a well-developed public system of home care, cutbacks in the latter as well as reductions in the former have followed the drive towards restructuring in the 1980s and 1990s. This was also due to the economic pressures generated by the important economic downturn at the beginning of the 1990s (See Heikkilä Uusitalo 1997). In Germany, recipients of payments from the insurance regime can mix their use of informal care and formal services, with the later being provided by a range of agencies. In Germany, the home care sector has not received the boost it might have expected, as recipients of Long-term Care Insurance take their payments mainly in cash rather than service packages (Ostner 1998) - even though the (nominal) value of service packages in kind is higher than the cash alternative.

99. In terms of the women workers who provide formal services, the consequences are varied. France reports substitution of more precarious and certainly more part-time jobs for what were relatively "good" jobs for home care providers. This is due to the fiscal and institutional aspects of the new benefit (PSD), which makes it financially more attractive for the recipient to employ a care-giver directly, under personal services contracts, which are by nature more precarious, than through an agreed provider of formal care services (Hespel Thierry, 1998). The pressure generated on their market has made the situation of these agreed providers difficult, although recent fiscal changes in the 2000 budget are aimed at correcting this situation. In France, because the government's goal was as much to reduce unemployment as to deal with the issue of care for the frail elderly, the measures of success is often the number of jobs created. However, it is difficult to know the quality of the jobs that are created, as they are mostly part-time and low-paid (Lallement, 1998).

100. Germany reports an interesting dual effect. On the one hand, the new insurance regime has brought recognition of a new job status, that of registered Informal Caregiver, which is in some sense parallel to the formal care sector. In part, this result follows from a more general policy stance emerging in Germany, which is to encourage women to enter the labour force, particularly via part-time employment. This new status carries rights and provides some recognition for the low-paid and not too secure jobs in field of care for the elderly (see section 4.2, Table 9 below). It seems also that the sort of price competition and market mechanisms which had been hoped to boost the provision of home care services did not develop as fully as expected, as happened in Austria. The delivery of care remains more or less the responsibility of exclusive providers at the local level, due to religious or cultural characteristics of geographical areas. In addition, the amount of additional cash injected in the systems seems to have driven prices upwards.

Table 9. How is it paid? Labour market eligibility rules and amounts 
101. The other side of the coin is that availability of new funds in the system had prompted a certain amount of up grading for the training and professional credentials of those with relatively good jobs in the sector. Therefore, the overall conclusion is that there has been both an increase of professionalism and a rise in precarious work, the latter result mirroring the French pattern.

102. In the other countries, there is either no data available on the substitution effects, or the effects appear to be minimal, because - as noted above - the payments primarily go to women who were already providing care.

\subsection{How is the care benefit paid? And the consequences for women's futures}

103. There are several models for paying care benefits, and these are likely to have different consequences for women who provide care. These consequences depend both on eligibility rules with regard to labour market, whether labour market participation remains possible or not, on the level of payment and how it compares with old age public income support (Table 9). The consequences for women's future depend also on the long-term social rights attached to benefits, such as pension rights (Table 10).

\section{Table 10. Forms of payment for informal caring work provided by payment for care}

104. In Australia and Canada the employment or income situation of the caregiver is taken into account in determining eligibility. In Australia, the Carers Payment is supposed to be a substitute for income lost; therefore it is paid at close to the rate of Unemployment Insurance or means-tested pensions and recipients may not engage in full-time work. As care-givers reach 60 to 65, and become eligible for Age Pensions, they are no longer eligible for the Carers Payment. However, the Carers Payment is not truly a substitute for income lost, it should be noted, because recipients are not credited with superannuation contributions, despite the fact that the payment rate is above the cut-off for participation for employees (Mears 1998). In Canada, in the Nova Scotia Home Life Support Programme, the caregiver was income-tested, so that only the poorest were eligible. Neither this programme, nor those in Quebec or the federal tax credit provide the carers with any pension rights (Fast 1998).

105. Therefore, the consequence for care-givers in these two countries is that, unless they have other means of access to pension regimes, they are likely to find themselves receiving the bare minimum of retirement pensions. That is, they are likely to be close to poverty levels when they themselves are retired. Not surprisingly, then, despite having heavy care responsibilities, workers seem to hang on to the labour force status as much as possible, as indicated by the relatively small part these payments play in the overall provision of care for the dependent elderly (see Table 3 above).

106. Finland provides another model via the ICA. While care-givers are not prohibited from labour force participation, there is also recognition that they may not be able to participate and accumulate their own social benefits, especially for pensions. Therefore, the ICA may be paid at a rate, which is close to that of an average pension, and care-givers receiving an ICA have the employment status "Care-giver of a relative". This gives them access to basic occupational rights and credits towards a pension (Anttonen 1998). Austria followed a similar model when it instituted the Attendance Allowance. Care-givers caring for a very dependent person could choose to opt into pension insurance and to thereby accumulate occupational benefits (Holzman Jenkins 1998). Similarly, in Germany creation of the insurance regime and the new occupational status of family care-giver offers women the opportunity to accumulate benefits. Finally, in France where the care benefit (PSD) permits recipients to hire care-givers, including unemployed family members, the payment for care opens access to regular occupational benefits, in terms 
of pensions and unemployment insurance. However, these are earnings-related in the French context and are therefore at relatively low levels (Joel and Martin 1998).

107. Payments for care may in all the countries involved in the study involve at least some form of short term monetary compensation. However, access to long term compensation or other forms of compensation remains limited (Table 10). In order to participate, care-givers must meet the minima set by each pension scheme. For example, of the European Union countries examined for this project, only France does not establish a minimum earned income in order to enrol in the pension regime. Care-givers will not be building their own long-term entitlements to pension or invalidity benefits, when they can not take up full time paid jobs or must take low-paying part time jobs because of caring responsibilities. This is also the case when they do not receive a income from the person for whom they are caring, or when their caring earnings are too low. They are therefore at risk of not accumulating social rights from social insurance (DG-V, 1995).

108. The formal retirement benefits conferred on participants in the Finnish, German, Austrian and French programmes and they contrast in important ways with those of Australia and Canada, which do not combine their payments to any protection of the economic future of informal care-givers. Yet, even those that do provide some social protections do so at the lowest rates. They are, as well as the schemes that provide none, building a future in which the poverty levels of older women are likely to remain disproportionately high -- particularly for older single women.

109. Another important characteristic of the programmes for payments for care lies in the provision of other forms of compensation and supplementary services to care-givers. As Table 10 documents, most provide some kind of respite care, recognising the immediate needs of care-givers for relief from the hard work of care. In Quebec, for example, the only payment available to carers is an allowance for respite care. Fewer programmes, however, pay much attention to the longer-term needs of carers, such as reintegration into the labour force once the stint of caring has ended. Germany does provide access to vocational training for carers returning to labour force, but it is more the exception than the rule ${ }^{14}$. In part this gap may be due to the fact that care-givers are, in general, either elderly women past retirement age, or women in their 40s and 50s. Nonetheless, in the case of the latter, their economic future is not secured by programmes, that ignore their potential need for employment, particularly for the relatively younger care-givers.

\subsection{How is it used? Benefits in cash or in kind and their consequences for women's incomes}

110. Materials gathered in the course of this project identified situations in which the family economy was rendered complicated by the way the benefit was paid. In Germany, for example, where the overwhelming choice is cash rather than services, or in Austria where the benefit is paid only in cash, there is no guarantee that any of it will end up in the hands of the person providing the care. Recipients are free to spend (or save) as they wish, to disburse the benefit as a gift, or to purchase services to "lighten" the burden of the informal care provider. Patterns of use of the benefit are provided in Table 11. Where cash benefits are paid to frail elderly with a free choice, as in Germany, there is an overwhelming preference for taking the benefit in cash rather than services: the home care option is taken by $71 \%$ of recipients. Of these, the overwhelmingly majority of those recipients took cash, with the rest taking some combination of cash and services or a home care package (Ostner 1998).

Table 11. How is it used? Patterns of use of benefits

14. However, they are not entitled to unemployment insurance unless they have had a labour contract (EU-DGV, 1995: 144). 
111. In Austria, where a quite similar benefit can only be taken in cash, the use of formal services is quite limited (Holzman Jenkins 1998). As long as a family care provider was available, only 2 out of every 5 recipients living with a spouse or other family member purchased any services. Moreover, very few made any kind of regular payment to their primary care provider. Women providing care would be paid only after the non-family services had been covered, or not at all. Thus, as Table 11 report, of those caring for recipient of an Attendance Allowance, a mere $1.2 \%$ have a formal contract, and only $25 \%$ received a regular payment. Fully one-third had no explicit or formal arrangement and 14\% received no money whatsoever for the caring work.

112. In France, the findings are derived from an experimental study of pre-PSD experiments (Joel and Martin 1998). These findings show that patterns of hourly use of payments for care varied, but there was a clear preference for employing a care-giver. Almost two in five recipients hired an individual employee to come into their home, but less than one-quarter hired a family member, perhaps because of the requirement that the family member be unemployed at the time of engagement. Thus, France seems to have moved in the direction of achieving the primary goal of its policy - that is, to create jobs and render care work more formal, although more formal does not necessarily mean less precarious. However, it is also important to remember that in France such payments cover the needs of a very small part of the dependent elderly (Table 3). In Germany as well, the rise in registration of informal care-givers helped to foster employment, at least part-time.

113. Overall, then, and with perhaps the exception of Finland, there is not much evidence that these payments have a significant impact on the income of women who are providing care. The income benefit is either more of a symbolic recognition, or sometimes it seems that it does not end in the purses of the women care-givers.

\subsection{A general perspective on care benefits and care work and their impact on women care- givers}

114. Care allowances do shift the incentive structures, although not necessarily in the ways that had been initially intended. Pijl (1994) reports that the design of such payments for care resulted from the belief that it was possible to expand the pool of family care-givers by inducing women to undertake informal care. This does not seem to be the overall result -- see Table 12, which presents a summary of the impact of care benefits. There does not seem to be much incentive for women or other care-givers to give up a paid job in order to take up a benefit. Comparing the available materials, the impact of the care benefit seems to be difficult to discern. In both Austria, which has one of the most generous benefits, and Canada, which has one of the most restricted ones, women are reducing their hours of work and their labour force participation because of their informal caring work. However, although evidence on this point is not conclusive, this seems more related to the intensity of care-giving needs than to the benefit per se on average. If there was a shift out of paid work or towards reduced hours, it was for those carers with the heaviest responsibilities.

\section{Table 12. Summary evaluation of the impact of care allowances}

115. Care allowances do not seem to generate large changes in labour force participation (and this was not their primary purpose) even if in some cases, they may have influenced some choices. However, they represent some compensation for the opportunity cost of care, improving the welfare of either the person being cared for, or women care-givers when part of the benefit is accrued to them.. The most advanced programmes have included recognition of the needs of the older disabled persons and also of the needs linked to informal care work, for example by jointly opening access to occupational benefits. However, even these are limited by the need to meet the requirements already set by pension and other regimes. 
These requirements are often usually shaped by a traditional vision of the welfare state, modelled on fulltime or at least continuous employment over the working life. Care-givers may find themselves unable to participate in these occupational benefits because they do not meet the requirements in terms of hours or income, or because the care work is interrupted by the sudden hospitalisation of the elderly person they are caring for. Precariousness remains very high.

116. Instituting such allowances does not seem to have the effect, which some feared, of lowering women's labour force participation. However, nor does it mean that they represent a way to promote gender equality, as they do not change the gender distribution of caring work. An unequal distribution of caring work contributes to income inequality, inequalities in retirement incomes, and in participation in social life (Status of Women Canada, 1997). In economic terms, the payments are set at modest levels, when considering the weight of the tasks, both physically and emotionally. However, they certainly represent some compensation for the opportunity costs, when they are higher than a symbolic compensation. Without these benefits, informal care-givers would certainly be worse off.

117. At the same time, these care allowances have ambiguous effects on the market for formal home care services. This market offered in some countries such as Finland, reasonably well paid and respected professions. On the one hand, there is a risk of partly reducing the job prospects of other women who might have been employed in providing home care services due to the competition from cheaper forms of care. These jobs may be reduced, as services may be directly purchased within the family at a lower cost. In France for example, use of formal services declined for reasons mentioned above and this has been acknowledged by public authorities as a matter of concern (Hespel Thierry). On the other hand, in Austria, care arrangements became relatively more stable than before the implementation of the Allowance and contrary to France, the implementation of the scheme led to pressures upwards for prices of formal care services.

118. Finally, an important dimension is that caring was reported to be a stressful activity for a majority of care-givers in those countries for which information is available (Australia, Canada, Germany and Japan). Consequences for care-givers' health could also be discerned, such as changing sleep patterns, as reported by one-third of care-givers in Canada, and even sleeplessness reported by a fourth of Japanese care-givers. These issues are well known in the field of gerontology where a number of scales have been developed to measure the burden of caring, particularly in the case of dementia (Zarit et al. 1999). The Zarit scale involves 22 questions documenting the physical, psychological and social and financial implications of care work. This literature report that it is important for both the clients and their family to receive adequate amount of help, including in-home respite, adult day care, overnight respite, with a specific attention to dementia. In the materials gathered for this project, care-givers reported feeling that they were the only ones available to provide care. This reinforced the felt burden, particularly for those who had the heaviest responsibilities. 
DEELSA/ELSA/WD(2000)2

\section{CONCLUSION: FROM PAYMENT TO RECOGNITION}

119. Payments for care reflect the trend towards the promotion of individual "choice" and "selfmanaged care", which also influences the design of welfare systems. Some among OECD countries have instituted care benefits in response to this movement, and have also started to recognise long-term care as a real risk of life. However, there are two sides to the coin. The notion of choice for recipients ignores the effects of pre-existing and long-standing inequalities in the household distribution of work and their impact on gender equality. This seems to have important consequences in some of the countries in the field of this study, such as Japan, where women report being "trapped into care work" (Higuchi 1998).

120. Despite -- or even because of -- such complex changes in policy direction, basic issues of choice about social citizenship have to be untangled and the consequences of choices identified. The active participation of family care-givers is crucial for pursuing the social goal of "ageing in place". However, this cannot be simply assumed, or regarded as a "free good". There are well-documented costs to caregivers, in time, in stress, and also in their own health.

121. Therefore, as these studies show, in Australia, Japan, Canada and Finland, adequate support services so that those providing elder care can "reconcile work and family life" are often not yet available to informal carers. It is crucial that, in future, social policies not only address the disabled persons themselves, but the dyad of the care-giver and the person being cared for, as a social entity in need of support. Services have to be organised in such a way as to complement family care. They should treat those care-givers who provide the greatest amounts of care as clients in their own right.

122. The report points to the fact that short-term monetary compensation does not by itself address the multiple needs associated with caring responsibilities. Some of these needs, as expressed in surveys of care-givers, are presented in Table 13. Clearly, an upward adjustment of the care allowances would better offer compensation for the foregone costs. But there is also a need to consider longer-term forms of compensation and additional support services.

123. Social rights, associated with caring responsibilities, are needed to avoid care-givers becoming trapped into long-term poverty because they have assumed care-giving responsibilities in the past. In many public pension systems such as in Sweden, pension credits are conferred for the time spent in childbearing. In some of the countries studied, , pension rights can also be earned by those providing care to the elderly and infirm. Such recognition of the social value of care-givers warrants emulation.

124. A second need, which applies mainly to care-givers who are or could potentially be participating in the labour market, is related to both flexible arrangements and the possibility of return to the labour market. Flexi-time schedules, leave of absence policies would provide both a possibility to continue working while assuming care responsibilities and a possibility to return to work. (Twigg, 1996). Caregivers mention in surveys the need for more flexibility from employers, so that it is possible for them to combine informal care work with employment. Such flexibility includes the possibility of taking leave, of reducing hours of work without major penalties, and having more flexible daily and weekly schedules (Table 13). Few countries have moved very far in this direction. Again, policies for the care of young children, limited as they are, have made much greater progress than have those for the frail elderly. There 
are currently few guarantees of training or assistance with access to a job for those who wish to return to work in the wider labour market after providing care.

\section{Table 13. Support desired by care-givers}

125. In addition to these family-friendly labour market arrangements, some efforts could also be made to rebalance the gender burden of caring work, as is the case with child care. Whereas many parental leave programmes seek to provide real incentives to fathers to assume their caring responsibilities, nothing comparable has done as of yet in the field of elder care. Detailed studies find men who do perform caring work, in particular in the case of a frail spouse. However, this goes along with gender bias in the distribution of care tasks, with women taking the main role in the provision of personal care.

126. Third, due to the health consequences of caring, an important part of care-givers needs lies in an adequate infrastructure which makes it possible to cope with the burden of informal caring. As Table 13 reports, respite care - some relief from the constant pressure of care work - was mentioned in inquiries in most countries studied. While several countries do have programmes for respite care, Finland goes the furthest, requiring municipalities to provide a weekend of respite each month. Australia and Canada also report respite care as part of their package of home care services. This could, however, be more developed, and needs for counselling, support, home respite, adult day care, overnight respite (with a specific attention to dementia) all require attention. Current systems for providing additional support seem to be far from matching those needs. This should be viewed in a global cost-effectiveness perspective. The exhaustion of care-givers, and often a sudden deterioration of their own health can result in a joint hospitalisation of both the caregiver and the person being cared for.

127. In conclusion, if the goal of policies paying care benefits was to reinforce provision of care by family members, and thereby to rebalance the welfare diamond in the direction of the family and the market, they are succeeding. However, a fuller understanding of the notion of "real choice" should also include the other side of the coin, and provide more equal opportunities and human support to the informal care-givers who still provide over four fifths of care for the dependent elderly. 


\section{REFERENCES}

ALBER, J. (1996) "The Debate about Long-term Care Reform in Germany"", in OECD, Caring for Frail Elderly People, Social Policy Studies, ${ }^{\circ} 19$.

ANTTONEN A. (1998) Paying for Care: Repercussions for Women Who Care, the case of Finland, the case of Finland, University of Tampere, Department of Women's Studies. Mimeo.

AUSTRALIAN BUREAU OF STATISTICS (ABS) (1995) Focus on Families: Caring in Families: Support for persons who are older or have disabilities, Catalogue $\mathrm{N}^{\circ} 4423.0$, Canberra?

AUSTRALIAN BUREAU OF STATISTICS (ABS) (1999) Disability, Ageing and Carers: Summary of Findings 1998, Focus on Families: Caring in Families, Support for Persons Who are Older or Have Disabilities. Canberra.

AUSTRIAN FEDERAL MINISTRY OF LABOUR HEALTH AND SOCIAL AFFAIRS (1994) Provision for long-term care in Austria. Vienna.

AUSTRIAN FEDERAL MINISTRY OF LABOUR, HEALTH AND SOCIAL AFFAIRS (1998) The Austrian Welfare System: A survey of social security systems, M. Hörndler, K. Wörister, H. Rack, J. Bauernberger, H. Steiner. Vienna.

BUNDESMINISTERIUM FUR ARBEIT UND SOZIALORDNUNG (1998). Bericht über die Entwicklung der pflegeversicherung, Bonn, January.

BOAZ R. (1996) Full-Time Employment and Informal Care-giving in the 1980s, Medical Care, 34(6), pp. 524-536.

BOAZ R., MULLER C.F. (1992) Paid Work and Unpaid Help by Care-givers of the Disabled and Frail Elders, Medical Care 30(2) pp. 149-158.

BRODY E.M., SCHOONOVER C.B. (1986) Patterns of parent-care when adult daughters work and when they do not. The Gerontologist, 26, 372-381.

CARMICHAEL F., CHARLES S. (1998) The Labour Market Costs of Community Care, Journal of Health Economics, 17, 6, 645-798.

CARMICHAEL, F., S. CHARLES (1998) “The Labour Market Costs of Community Care”, Journal of Health Economics, 17:6, 747-67.

CHRISTOPHERSON, SUSAN (1997) Childcare and Elderly Care: What Occupational Opportunities for Women?, OECD Labour Market and Social Policy Occasional Papers, $\mathrm{n}^{\circ} 27$.

COMMAILLE, J. MARTIN C. (1998) Les enjeux politiques de la famille (Paris: Bayard) 
COMMONWEALTH DEPARTMENT OF HEALTH HOUSING AND COMMUNITY SERVICES (1993), Aged Care Reform Strategy, Mid Term Review, Stage 2, Australian Government Publishing Services, Canberra.

\section{COMMONWEALTH DEPARTMENT OF HEALTH HOUSING AND COMMUNITY SERVICES} (1991) Aged Care Reform Strategy Mid-Term Review, September. Australian Government Publishing Services, Canberra.

DG-V OF THE EUROPEAN COMMISSION (1995) Europe. Social Protection (Brussels: European Commission).

ESPING-ANDERSEN G. (1997) Welfare states at the end of the century: the impact of labour market, family and demographic change, in Family, market and community, OECD, Social Policy Studies $n^{\circ}$ 21.

ESPING-ANDERSEN, GØSTA (1990) The Three Regimes of Welfare Capitalism (Princeton, NJ: Princeton University Press).

ETTNER, S.L. (1995) The Impact of Parent Care on Female Labour Force Supply Decisions", Demography, 32:1, 63-80.

ETTNER, S.L. (1996) “The Opportunity Costs of Elder Care”, Journal of Human Resources, 31:1, 189205.

EUROPEAN SOCIAL NETWORK (1998) Towards a People's Europe, a Report on the Development of Direct Payments in 10 Member States of the European Union, funded by the European Commission, DGV.

EVERS, ADALBERT (1994) "Payments for Care: A Small but Significant Part of a Wider Debate" in Adalbert Evers, Marja Pilj and Clare Ungerson (eds), Payments for Care (Aldershot, UK: Avebury).

EVERS, ADALBERT AND I SVETLIK (EDS) (1993) Balancing Pluralism. New Welfare Mixes in Care for the Elderly (Aldershot, UK: Avebury).

FAST J., MAYAN M. (1998) Paying for Care: Repercussions for Women Who Care, the case of Canada, University of Alberta, mimeo.

FAST, J, WILLIAMSON D., KEATING N.C,(IN PRESS) "The hidden costs of informal elder care", Journal of Family and Economic Issues.

FREDERICK, J. KELLY A., CRANSWICK A., NORRIS D. (1998) Measuring Social and Community Support: The Canadian Experience, UN Statistical Commission and Economic Commission for Europe, Conference of European Statisticians, Geneva, 20-22 April.

FUCHS V.R. (1990) Women's Quest for Economic Equality, Harvard University Press.

GRAMAIN, A. (1998), "The costs of long-term care according to living arrangements: a survey", working party on social policy meeting October, room document, OECD, Paris.

GRAMAIN, A. (forthcoming), "Les facteurs de recours à l'aide formelle dans la prise en charge de la dépendance (The factors of influencing recourse to formal help in the care for frail elderly persons)", Labour Market and Social Policy Occasional Paper, OECD, Paris. 
HALTON, J. (1998), “Ageing in Australia: the Policy Response”, Aged and Community Care, Commonwealth Department of Health and Family Services, May, (mimeo). Presented at an OECD internal seminar in April 1998.

HEIKKILÄ M. UUSITALO H. (1997) The Cost of Cuts, studies on cutbacks in social security and their effects in the Finland of the 1990s, STAKES. Helsinki.

HESPEL V., THIERRY M. (1998) Synthèse des constats et propositions de la mission sur les services d'aide aux personnes, Inspection Générale des Finances, Inspection Générale des Affaires Sociales, Paris.

HIGUCHI K. (1995) Bringing up Girls, translated by akiko Tomii. Shoukadoh Booksellers, Kyoto.

HIGUCHI K. (1997) Towards a Bright and Cheerful Aged Society with Fewer Children, Tokyo Kasei University.

HIGUCHI K. (1998)a Enactment of Care Insurance Scheme and Family Relations in Japan, Beijing International conference on Family, Social Welfare and Social Security.

HIGUCHI K. (1998)b Status of Elder Care in Japan, International Conference of Carers Association, June. London.

HIGUCHI K. (1999) Paying for Care: Repercussions for Women Who Care, the Case of Japan Tokyo Kasei University, Women Association for Better Ageing Society.

HOLZMAN JENKINS A. (1998) Paying for Care: Repercussions for Women Who Care, the case of Austria, , Sozialökonomische Forschungsstelle, Vienna. Mimeo.

HUTTEN J.B.F. KERKSTRA (1996) Home Care in Europe. Ashgate Publishing Company, Aldershot. England.

IHARA K, AMAIKE M. (1997) A New Care System for the Elderly in Japan, Establishment of LongTerm care insurance, August. JETRO New York.

INTERNATIONAL LONGEVITY CENTER (1994), An Economic Comparison of US and Japanese Systems of Health Care for the Elderly, Tokyo, March.

JACOBZONE, S (1999) Ageing and Care for Frail Elderly Persons: An Overview of International Perspectives, OECD Labour Market and Social Policy Occasional Papers, $\mathrm{n}^{\circ} 38$.

JACOBZONE, S. (1999), Ageing and Care for Frail Elderly Persons: An Overview of International Perspectives Labour Market and Social Policy Occasional Papers $n^{\circ} 38$, OECD, Paris.

JAMIESON A. ILLSLEY R. (1990) Contrasting European Policies for the Care of Older People, Avebury, Aldershot.

JENSON J. (1997) "Who Cares? Gender and Welfare State Regimes", Social Politics. International Studies in Gender, State and Society, vol 2:4.

JOEL M.E., MARTIN C. (1998) Paying for Care, les répercussions pour les femmes soignantes des politiques en matière de prise en charge des personnes âgées dépendantes. LEGOS Université Paris Dauphine IEP Université de Rennes I. Mimeo. 
JOËL, M.E., MARTIN C. (1998) Aider les personnes âgées dépendantes. Arbitrages économiques et familiaux (Rennes: Éditions ENSP).

KALISCH D., AMAN T., BUCHELE L. (1998) Social and Health Policies in OECD Countries: A Survey of Current Programmes and Recent Developments, OECD Labour Market and Social Policy Occasional Papers $n^{\circ} 33$.

KAZUNORI, Y. (1996) "Merits and Demerits of 'Care Insurance'", Japanecho, vol. 23.

KEATING, N. C., FAST, J. E., FREDERICK, J. A., CRANSWICK, K., PERRIER, C. (1999). Eldercare in Canada: Context, content and consequences. Ottawa:Statistics Canada.

KILLINGSWORTH, M. R. HECKMAN, J.J. (1986) Female Labor Supply: A Survey, in Handbook of labor economics, Ashenfelter,O. and Layard, R. ed. North-Holland; pp. 103-124.

KNIESNER T.J. LOSASSO A.T. (1998) New Evidence on Interngenerational Risk Sharing, Department of Economics, Indiana University, Institute for Health Services Research, Northwestern University, December. Presented at the American Economic Association meeting, New York. January 1999.

LALLEMENT M. (1998) "Famille et emplois de service", in Margaret Maruani, Les nouvelles frontières de l'inégalité. Hommes et femmes sur le marché, du travail (Paris: La Découverte/MAGE, 1998)

LAMURA G., MELCHIORRE M.G., TARABELLI D., CIARROCHI S., QUATTRINI S., MENGANI M. (1998) Elderly Care in Italy: Policy Implications Coming from Current Socio-Demographic Trends and Recent Empirical Findings on Family Caregiving. Gerontological Research Department Ancona.

LEVINE C. (1999) The Loneliness of the Long-Term Care Giver, New England Journal of Medicine1999, May 20, 1587-1590.

LUMSDAINE R. (1998) Caring for Grandchildren and the Retirement Decision, NBER Summer Institute 1998, Brown University mimeo.

MARINO, P. TEISSIER N. WERLE J. (1998) Institutionalisation des personnes âgées dans dix pays de l'OCDE : Le coût de prise en charge de la dépendance, Rapport d'étude pour l'OCDE.

MASAMURA K, HIGUCHI K. (1996) Care for the Elderly: Who Will Bear the Burden? Japanecho, winter..

MEARS J. (1998) Paying for Care: Repercussions for Women Who Care, the case of Australia, University of Western Sydney, Department of Social Policy and Human Services, Faculty of Arts and Social Sciences. Mimeo.

MOEN P., ROBISON J., FIELDS V. (1994) Women's Work and Caregiving Roles: A Life Course Approach, Journal of Gerontology, Social Sciences, 49, 4, S176-S186.

MUURINEN J.M. (1986) The Economics of Informal Care, Labour Market Effects in the National Hospice Study, Medical Care, 24, pp. 1007-10017

ODA K. SATO S., IWAI M., KUBO H. (1997) Monetary Valuation of Unpaid Work, Department of National Accounts, Economic Research Institute, Economic Planning Agency. 
OECD (1981) The Welfare State in Crisis. An account of the Conference on Social Policies in the 1980s, OECD, Paris 20-23 October 1980.

OECD (1994) Women and Structural Change, New Perspectives OECD Paris.

OECD (1995) Household Production in OECD Countries, Data Sources and Measurement Methods. Paris.

OECD (1996) Caring for Frail Elderly People, Social Policy Studies, ${ }^{\circ} 19$.

OECD (1996), Caring for Frail Elderly People, Policies in Evolution, Social Policy Studies $N^{\circ} .19$, Paris.

OECD (1997)a, Ageing in OECD Countries, A Critical Policy Challenge, Social Policy Studies $\mathrm{N}^{\circ} .20$, Paris.

OECD (1997)b Family, market and community, Equity and Efficiency in social policy, Social Policy Studies $n^{\circ} 21$.

OECD (1998a) The Future of Female-Dominated Occupations. Paris.

OECD (1998b), Maintaining prosperity in an Ageing Society, Paris.

OKUMA Y. (1998) Women's roles as care-givers: family, worker, volunteer. Keio Journal of Medicine, 47, Supplement 2. pp. 14-15.

OSTNER I. (1998) Paying for Care: Repercussions for Women Who Care, the case of Germany, GeorgAugust-Universität, Institut für Sozialpolitik, Gottingen, Germany.

PACOLET J., BOUTEN R., LANOYE H., VERSIECK (1998) Social Protection for Dependency in Old Age in the 15 EU Member States and Norway, Comparative study, research project for the European Commission DGV/E and the Belgian Minister of Social Affairs.

PENCAVEL,J. H. (1986) Labor Supply of Men: A Survey in Handbook of labor economics, Ashenfelter,O. and Layard, R. ed. North-Holland; pp. 3-102.

PENROD J.D., KANE R.A., KANE R.L., FINCH R.L. (1995) Who Cares? The Size, Scope, and composition of the caretiver support system. The Gerontologist, 35, 489-497.

PIJL, M (1994) "When Private care Goes Public" in Evers A., Pilj M. and Ungerson C. (eds), Payments for Care (Aldershot, UK: Avebury).

PITROU, A. (1997) "Vieillesse et famille : qui soutient l'autre ?", Lien Social et Politiques-RIAC, \#38.

ROSENTHAL, C. (1997) "Le soutien des familles canadiennes à leurs membres vieillissants : changements de contexte", Lien Social et Politiques-RIAC, $\mathrm{n}^{\circ} 38$.

ROSTGAARD T., FRIDBERG T. (1998) Caring for Children and Older People, A Comparison of European policies and Practicies, Social Security in Europe $n^{\circ} 6$, The Danish National Institute of Social Research 98:20.

SARACENO C. (1997) Family change, family policies and the restructuring of welfare, in Family, market and community, OECD, Social Policy Studies $n^{\circ} 21$. 
SCHNEIDER U. (1999) Germany's social long-term care insurance: Design, implementation and evaluation, International Social Security Review, 52, 31-74.

SCHNEIDER U., WOLF D. (1990) Time Allocation Impacts of Parent-Adult Child Co-residence: A Panel analysis for the US, Thirtieth Annual conference of the German society for Population Studies, Luxembourg April. University of Hannover, University of Syracuse, mimeo.

SCHOFIELD H., Bloch S., Herrman H., Murphy B., Nankervis J., Singh B. (1998) Family Care-givers, Disability Illness and Ageing, Allen and Unwin Victorian Health Promotion Foundation, Australia.

SHINOTSUKA E. (1998) The Supply of Manpower for Care Services from the Viewpoint of Care Insurance, Review of Population and Social Policy, $\mathrm{n}^{\circ}$ 7, 15-43.

SIPILÄ, J. ANTTONEN A. (1994) "Payments for Care: The Case of Finland" in Adalbert Evers, Marja Pilj and Clare Ungerson (eds), Payments for Care (Aldershot, UK: Avebury).

SODEI T. (1998) Role of the family in long-term care, Keio Journal of Medicine, 47, Supplement 2. pp. 16-17.

SOLDO B.J., HILL M.S. (1995) Family Structure and Transfer Measures in the Health and Retirement Study. Journal of Human Resources. 30, 108-137.

SOLDO B.J., MYLLYLUOMA J. (1983) Care-givers who Live with Dependent Elderly, The Gerontologist, 23,6, 605-611.

STATISTICS CANADA (1997) A Portrait of Seniors in Canada, Housing Family and Social Statistics Division.

STATUS OF WOMEN CANADA (1997) Report on the Think-Tank on Policy Research on Unpaid Work, November.

STATUS OF WOMEN CANADA (1998) Who Will Be Responsible for Providing Care? The Impact of the Shift to Ambulatory Care and of Social Economy Policies on Quebec Women, Association féminine d'éducation et d'action sociale, Côté D., Gagnon E., Gilbert C., Guberman N., Saillant F., Thivierge N., Tremblay M.

STERN S. (1995) Estimating Family Long-Term Care Decisions in the Presence of Endogenous Child Characteristics. Journal-of-Human-Resources; 30(3), pp. 551-80.

STONE R.I., FARLEY-SHORT P. (1990) The Competing Demands of Employment and Informal Caregiving to Disabled elders, 28,6, 513-526.

STONE R.I., KEMPER P. (1989) Spouses and Children of Disabled Elders: How Large a Constituency for Long-Term Care Reform? The Milbank Quarterly, 67(3-4), 485-506.

SWANE C.E. (1998) The Relationship between Formal and Informal Care, Keio Journal of Medicine, 47, Supplement 2. pp. 18-20.

TILLY J., BECTEL R. (1999) Consumer-Directed Long-Term Care: Participant's experiences in five Countries, AARP, Washington DC.

TILLY J., WIENER J., EVANS CUELLAR A. (2000) Consumer-Directed Home Care for Older People in Five countries: Who is in Charge ? The Urban Institute, Washington, mimeo. 
TWIGG, J. (1996) "Issues in Informal Care", in OECD, Caring for Frail Elderly People, Social Policy Studies, $\mathrm{n}^{\circ} 19$.

VAARAMA M., KAUTTO M. (1997) Social Protection for the Elderly in Finland, STAKES,

WAERNESS, K., RINGEN S. (1987) "Women in the Welfare State: The Case of Formal and Informal Old-Age Care", in R. Erikson et al., The Scandinavian Model: Welfare States and Welfare Research (NY: M.E. Sharpe).

WOLF D.A., SOLDO B.J. (1994) Married Women's Allocation of Time to Employment and Care of Elderly Parents, Journal of Human Resources, XXIX, 4, 1259-1276.

ZARIT S., GAUGLER J.E., JARROTT S.E. (1999) Useful Services for Families: Research Findings and Directions, International journal f Geriatric Psychiatry, 14(3), pp. 165-177. 
ANNEX

TABLES AND CHARTS

Table 1. Relationship of the care recipient to the informal caregiver

\begin{tabular}{|c|c|c|c|c|}
\hline $\begin{array}{l}\text { AUSTRALIA } * \\
* \text { relationship of all carers }\end{array}$ & \multicolumn{2}{|c|}{$\begin{array}{r}\text { partner } \\
\text { own child } \\
\text { other }\end{array}$} & \multicolumn{2}{|l|}{$\begin{array}{l}43 \% \\
26 \% \\
31 \% \\
\end{array}$} \\
\hline $\begin{array}{l}\text { AUSTRIA* } \\
\text { *relationship to the recipient of an Attendance } \\
\text { Allowance }\end{array}$ & $\begin{array}{r}\text { pa } \\
\text { own } \\
\text { son/daughter-in } \\
\text { unrel }\end{array}$ & $\begin{array}{l}\text { ther } \\
\text { hild } \\
\text {-law } \\
\text { ated }\end{array}$ & $\begin{array}{l}28 \% \\
32 \% \\
10 \% \\
12 \%\end{array}$ & \\
\hline $\begin{array}{l}\text { CANADA* } \\
\text { *relationship to all care recipients }\end{array}$ & \multicolumn{3}{|c|}{$\begin{array}{l}\text { \% of female } \\
\text { carers } \\
5 \% \\
57 \% \\
4 \% \\
16 \% \\
18 \% \\
1 \%\end{array}$} & $\begin{array}{l}\% \text { of male } \\
\text { carers } \\
4 \% \\
54 \\
3 \% \\
17 \% \\
21 \% \\
-\end{array}$ \\
\hline $\begin{array}{l}\text { FINLAND* } \\
* \text { daily help sources for all persons over } 60(>100)\end{array}$ & \multicolumn{2}{|c|}{$\begin{array}{r}\text { partner } \\
\text { child or grandchild } \\
\text { other relative } \\
\text { neighbour } \\
\text { friend } \\
\end{array}$} & \multicolumn{2}{|l|}{$\begin{array}{l}49 \% \\
50 \% \\
15 \% \\
11 \% \\
10 \% \\
\end{array}$} \\
\hline FRANCE & \multicolumn{2}{|c|}{$\begin{array}{r}\text { partner } \\
\text { sibling } \\
\text { child or grandchild } \\
\text { other relative } \\
\text { friend }\end{array}$} & \multicolumn{2}{|l|}{$\begin{array}{l}18 \% \\
53 \% \\
2 \% \\
5 \% \\
12 \%\end{array}$} \\
\hline $\begin{array}{l}\text { GERMANY* } \\
* \text { all long-term care recipients }\end{array}$ & \multicolumn{2}{|c|}{$\begin{array}{r}\text { partner } \\
\text { child } \\
\text { daughter-in-law } \\
\text { sibling } \\
\text { other relatives } \\
\text { friend } \\
\text { other }\end{array}$} & $\begin{array}{l}28 \% \\
22 \% \\
7 \% \\
2 \% \\
4 \% \\
3 \%\end{array}$ & \\
\hline $\begin{array}{l}\text { JAPAN* } \\
\text { The comprehensive survey of living conditions of } \\
\text { the people on health and welfare, 1998, MHW. }\end{array}$ & \multicolumn{3}{|c|}{$\begin{aligned} & \text { Total } \\
\text { spouse } & 36 \% \\
\text { child } & 25 \% \\
\text { use of child } & 27 \% \\
\text { parents } & 10 \% \\
\text { hers, formal } & 2 \%\end{aligned}$} & $\begin{array}{l}\text { o-residents } \\
38 \% \\
22 \% \\
27 \% \\
9 \% \\
3 \%\end{array}$ \\
\hline
\end{tabular}

For all countries except Canada, numbers are expressed in percentage of total carers. 
Table 2. Formal and legal financial filial obligations for a parent in financial need

\begin{tabular}{|c|c|}
\hline AUSTRALIA & No legal obligation to support or to care for a parent. \\
\hline AUSTRIA & $\begin{array}{l}\text { In all provinces but not Vienna, strict filial financial obligations exists but is subject to income } \\
\text { testing. In Vienna, filial obligations have been abolished. }\end{array}$ \\
\hline CANADA & No statutory obligation to support or to care for a parent. \\
\hline FINLAND & No legal obligation to support or care for a parent. \\
\hline FRANCE & $\begin{array}{l}\text { Children are obliged to provide financial support to their needy parents (obligation } \\
\text { alimentaire). Costs incurred by public authorities to care for the person may be deducted before } \\
\text { the child inherits. There a strict obligation between spouses. }\end{array}$ \\
\hline GERMANY & $\begin{array}{l}\text { Filial obligation exists between child and parent (gesteigerte Unterhalts-pflicht), but is income- } \\
\text { tested. }\end{array}$ \\
\hline JAPAN & $\begin{array}{l}\text { Filial obligation exists between child and parent, but it is income-related when one applies for } \\
\text { the public benefits. }\end{array}$ \\
\hline
\end{tabular}


Table 3. Name of Benefit and take-up

\begin{tabular}{|c|c|c|c|c|}
\hline & Name of benefit & $\begin{array}{l}\text { Means testing and interaction with } \\
\text { other age benefits }\end{array}$ & $\begin{array}{l}\text { Rate of take up among } \\
\text { the frail elderly }\end{array}$ & $\begin{array}{l}\text { Rate of take up } \\
\text { among carers }\end{array}$ \\
\hline AUSTRALIA & $\begin{array}{l}\text { CARER PAYMENT } \\
\text { (formerly Carer Pension) }\end{array}$ & $\begin{array}{l}\text { The person receiving care must be in } \\
\text { receipt of a social security pension, or } \\
\text { meet income and assets tests. } \\
\text { At age } 65 \text { recipients have the choice } \\
\text { to transfer to age pension. } \\
\text { In general, the carer is required to be } \\
\text { involved in daily care and attention, } \\
7 \text { days a week }\end{array}$ & NA & $\begin{array}{l}3.7 \% \text { of the total } \\
\text { number of primary } \\
\text { carers; } \\
\text { approx. } 44 \% \text { of } \\
\text { eligible carers } \\
2.2 \% \text { of the total } \\
\text { number of primary } \\
\text { carers }\end{array}$ \\
\hline AUSTRIA & $\begin{array}{l}\text { ATTENDANCE } \\
\text { ALLOWANCE } \\
\text { Pflegegeld }\end{array}$ & $\begin{array}{l}\text { Non-income, non-asset tested. Rate } \\
\text { adjusted to care needs. ( } 7 \text { levels of } \\
\text { payment) } \\
\text { Available to care recipients }\end{array}$ & $\begin{array}{l}\text { about } 60 \% \text { of disabled } \\
\text { older persons, with a mild } \\
\text { definition of disability. } \\
\text { about } 100 \% \text { of eligible } \\
\text { persons, based on the } 7- \\
\text { level disability criteria. }\end{array}$ & NA \\
\hline CANADA & $\begin{array}{l}\text { QUEBEC - SELF- } \\
\text { MANAGED CARE } \\
\\
\text { QUEBEC - RESPITE } \\
\text { FOR CARERS }\end{array}$ & $\begin{array}{l}\text { Need-tested - recipient must be } \\
\text { eligible for placement in L-T care } \\
\text { facility plus } \\
\text { Means tested - recipient and carer } \\
\text { must be at or below the poverty line } \\
\text { Need tested } \\
\text { Need tested }\end{array}$ & $\begin{array}{l}60 \% \text { of the persons who } \\
\text { met both the dependency } \\
\text { criterion (eligible for a } \\
\text { nursing home) and the } \\
\text { income test applied to the } \\
\text { elderly person and the } \\
\text { carer. } \\
\text { A very limited number of } \\
\text { elderly may be permitted to } \\
\text { substitute an allowance for } \\
\text { direct service provision. } \\
\text { NA }\end{array}$ & $\begin{array}{l}\text { Use varies by local } \\
\text { area }\end{array}$ \\
\hline FINLAND & $\begin{array}{l}\text { INFORMAL CARER'S } \\
\text { ALLOWANCE } \\
\text { Omaisloidon Tuki } \\
\\
\text { PENSIONER'S CARE } \\
\text { ALLOWANCE } \\
\text { Eläkkensaajien hoiotuki }\end{array}$ & $\begin{array}{l}\text { Need tested - needs daily help and } \\
\text { support } \\
\text { Level is defined according to need } \\
\text { Carer remains eligible for other } \\
\text { pensions } \\
\text { Need tested - made on grounds of } \\
\text { functional ability (i.e., diminished } \\
\text { capacity to cope with ordinary } \\
\text { activities without assistance) }\end{array}$ & $\begin{array}{l}1.8 \% \text { of total elderly } \\
\text { persons (estimated to be } 20 \\
\% \text { of the potential eligible } \\
\text { persons) } \\
4 \% \text { of total elderly persons } \\
\text { (estimated to be } 40 \% \text { of } \\
\text { the potential eligible } \\
\text { persons) }\end{array}$ & $\begin{array}{l}\text { NA for all carers } \\
10 \% \text { of those carers } \\
\text { over } 65 \text { who care } \\
\text { for a chronically ill, } \\
\text { disabled or aged } \\
\text { person }\end{array}$ \\
\hline FRANCE & $\begin{array}{l}\text { DEPENDENCY } \\
\text { ALLOWANCE } \\
\text { Prestation spécifique } \\
\text { dépendance }\end{array}$ & $\begin{array}{l}\text { Need-tested based on assessment of } \\
\text { dependency } \\
\text { Means-tested -ceiling for income } \\
72,000 \text { FF (10,976.3 Euros) for an } \\
\text { individual, } 120,000 \mathrm{FF}(18,293.9 \\
\text { Euros) for a couple }\end{array}$ & $\begin{array}{l}1 \% \text { of total elderly persons } \\
\text { (estimated to be } 10 \% \text { of } \\
\text { the potential eligible } \\
\text { persons) } \\
12 \% \text { of the frail elderly } \\
\text { over } 65 \text { receive support } \\
34 \% \text { of the population } \\
\text { which qualifies for income } \\
\text { test }\end{array}$ & NA \\
\hline GERMANY & $\begin{array}{l}\text { LONG-TERM CARE } \\
\text { INSURANCE } \\
\text { Including domiciliary and } \\
\text { residential care. The } \\
\text { former provides payments } \\
\text { for care } \\
\text { Pflegegeld }\end{array}$ & $\begin{array}{l}\text { Need tested } \\
\text { Based on an assessment of } \\
\text { dependency } \\
\text { May be paid to a person living at } \\
\text { home, in sheltered housing, a service } \\
\text { flat }\end{array}$ & $\begin{array}{l}9.4 \% \text { of elderly (over } 60 \text { ) } \\
\text { receive benefits or } \\
\text { services, around } 100 \% \text { of } \\
\text { the eligible population }\end{array}$ & NA \\
\hline
\end{tabular}

NA - not available 
Table 4. Description of payment

\begin{tabular}{|c|c|c|}
\hline & $\begin{array}{l}\text { Legal limits on use or } \\
\text { availability }\end{array}$ & Goal of policy, intent of the benefit \\
\hline $\begin{array}{l}\text { AUSTRALIA } \\
\text { Carer Payment }\end{array}$ & $\begin{array}{l}\text { May only be received to age } 65 \\
\text { Carer may not be in full-time work }\end{array}$ & $\begin{array}{l}\text { Both are part of a larger policy to encourage community care, which also } \\
\text { includes other supports for carers (information, respite, home care, etc.). } \\
\text { The Carer Pension was renamed the Carer Payment in 1996. After age 65, } \\
\text { people have the choice to transfer to the Age Pension. }\end{array}$ \\
\hline Carer Allowance & $\begin{array}{l}\text { Available to those with heavy caring } \\
\text { responsibilities }\end{array}$ & $\begin{array}{l}\text { The Carer Allowance is intended to provide some compensation for the extra } \\
\text { costs of caring. }\end{array}$ \\
\hline $\begin{array}{l}\text { AUSTRIA } \\
\text { Attendance } \\
\text { Allowance }\end{array}$ & $\begin{array}{l}\text { No limits except need } \\
\text { Available to all permanent residents } \\
\text { in need of care, according to level of } \\
\text { dependency - 7-levels }\end{array}$ & $\begin{array}{l}\text { To enable dependent persons to remain at home. } \\
\text { Support people in need of care, by covering part of the additional costs. } \\
\text { Offer a choice about services and providers. } \\
\text { Provide an incentive for informal care. }\end{array}$ \\
\hline CANADA & & \\
\hline $\begin{array}{l}\text { Nova Scotia } \\
\text { programme }\end{array}$ & $\begin{array}{l}\text { Can only be used as a substitute for } \\
\text { residential care }\end{array}$ & $\begin{array}{l}\text { Enable low-income frail elderly to remain in the community } \\
\text { Help compensate low-income family caregivers of low-income frail elderly for } \\
\text { extra costs. }\end{array}$ \\
\hline $\begin{array}{l}\text { Quebec self- } \\
\text { managed care }\end{array}$ & $\begin{array}{l}\text { Payments are not supposed to go to } \\
\text { family members }\end{array}$ & $\begin{array}{l}\text { Allow disabled persons to design and manage their own care; to fill gaps in } \\
\text { public service provisions }\end{array}$ \\
\hline $\begin{array}{l}\text { Quebec respite } \\
\text { care allowance }\end{array}$ & $\begin{array}{l}\text { Use only to purchase respite care } \\
\text { services }\end{array}$ & Provide respite to carers with very heavy caring responsibilities \\
\hline FINLAND & & \\
\hline $\begin{array}{l}\text { Informal Carer's } \\
\text { Allowance }\end{array}$ & $\begin{array}{l}\text { Neither the ICA nor the Pensioner's } \\
\text { Care Allowance can be claimed if } \\
\text { the person is cared for in an } \\
\text { institution. }\end{array}$ & $\begin{array}{l}\text { Enable ageing in place. } \\
\text { Reduce costs of institutional care. } \\
\text { Support for informal caring. } \\
\text { Compensate for loss of income }\end{array}$ \\
\hline $\begin{array}{l}\text { Pensioner's } \\
\text { Allowance }\end{array}$ & $\begin{array}{l}\text { Available on the basis of } \\
\text { dependency need }\end{array}$ & $\begin{array}{l}\text { Enable ageing in place - at home or in protected living } \\
\text { Compensate for costs accrued in relation to informal care }\end{array}$ \\
\hline $\begin{array}{l}\text { FRANCE } \\
\text { Prestation } \\
\text { spécifique } \\
\text { dépendance }\end{array}$ & $\begin{array}{l}\text { Persons over } 60 \text { residing in France } \\
\text { Need tested - only those with the } \\
3 \text { highest of } 6 \text { levels on the national } \\
\text { scale of dependency (AGGIR) are } \\
\text { eligible } \\
\text { Must be used to buy services or pay } \\
\text { salaries }\end{array}$ & $\begin{array}{l}\text { Help the most frail and poorest in their own homes or in residential care. } \\
\text { Create jobs in the home help sector and thereby cut unemployment }\end{array}$ \\
\hline GERMANY & $\begin{array}{l}\text { Available on the basis of need } \\
\text { No limits on use } \\
\text { The recipient may choose between a } \\
\text { cash payment, domiciliary care } \\
\text { services or residential care. } \\
\text { The recipient may also choose } \\
\text { whether to spend or save the } \\
\text { payment for care. }\end{array}$ & $\begin{array}{l}\text { Keep the elderly at home as long as possible. } \\
\text { Reduce dependence on social assistance and cut expenditures. } \\
\text { Reduce placements in residential care. } \\
\text { Stimulate and activate social networks. } \\
\text { Reduce costs to families, especially children. } \\
\text { Recognise informal care work by creating a new professional status. }\end{array}$ \\
\hline
\end{tabular}


Table 5. Related programmes

\begin{tabular}{|c|c|c|c|}
\hline & $\begin{array}{l}\text { Reimbursement of medical } \\
\text { services received at home, } \\
\text { nursing }\end{array}$ & $\begin{array}{c}\text { Tax credits or other } \\
\text { supplementary benefits }\end{array}$ & $\begin{array}{c}\text { Relationship of care benefit to } \\
\text { health system }\end{array}$ \\
\hline AUSTRALIA & $\begin{array}{l}\text { Generally YES through Medicare and } \\
\text { the Home and Community Care } \\
\text { Program (HACC) }\end{array}$ & $\begin{array}{l}\text { Partly. Tax deductions for private } \\
\text { health insurance subscription }\end{array}$ & $\begin{array}{l}\text { The medicare and HACC program } \\
\text { are separate but payment schemes are } \\
\text { integrated }\end{array}$ \\
\hline AUSTRIA & $\begin{array}{l}\text { YES "medical" (defined by } \\
\text { regulation) home nursing is covered } \\
\text { by health insurance }\end{array}$ & No & $\begin{array}{l}\text { Financing separate from health. } \\
\text { Financed from general revenues } \\
\text { rather than by contribution } \\
\text { Provision separate from health } \\
\text { Assessment of care needs done by } \\
\text { physicians appointed by pension } \\
\text { insurance bodies }\end{array}$ \\
\hline CANADA & $\begin{array}{l}\text { Generally NO BUT in some } \\
\text { provinces home nursing care may be } \\
\text { available as part of the health care } \\
\text { system }\end{array}$ & $\begin{array}{l}\text { YES } \\
\text { increasingly tax credits are being } \\
\text { made available }\end{array}$ & $\begin{array}{l}\text { Depends on the province } \\
\text { Nova Scotia programme transferred } \\
\text { to Department of Health in } 1994 \text { (and } \\
\text { put on hold) } \\
\text { Quebec programmes are an integral } \\
\text { part of the health care system }\end{array}$ \\
\hline FINLAND & $\begin{array}{l}\text { YES - access to medical services at } \\
\text { home not officially affected by } \\
\text { receipt of either benefit }\end{array}$ & $\mathrm{NO}$ & $\begin{array}{l}\text { Usually (but not always) } \\
\text { administratively linked to health } \\
\text { system }\end{array}$ \\
\hline FRANCE & $\begin{array}{l}\text { YES, covered by public health } \\
\text { insurance. }\end{array}$ & $\begin{array}{l}\text { YES - employers of family service } \\
\text { workers have tax advantages; } \\
\text { some tax credits for the costs of } \\
\text { disabled person. }\end{array}$ & $\begin{array}{l}\text { Separate } \\
\text { Assessment is done by health } \\
\text { professionals; delivery is done by } \\
\text { regional governments }\end{array}$ \\
\hline GERMANY & $\begin{array}{l}\text { YES, provided by health insurance } \\
\text { system, but the boundaries are being } \\
\text { contested }\end{array}$ & $\begin{array}{l}\text { YES - some tax credits available for } \\
\text { supporting family members }\end{array}$ & $\begin{array}{l}\text { Both systems are integrated, as Long- } \\
\text { term Care Insurance is part of social } \\
\text { insurance. }\end{array}$ \\
\hline
\end{tabular}


Table 6. Who provides care?

\begin{tabular}{|l|l|}
\hline & $\begin{array}{c}\text { Percentage of women } \\
\text { among caregivers receiving a care benefit or caring } \\
\text { for a recipient of such a benefit }\end{array}$ \\
\hline AUSTRALIA & $59.9 \%$ of recipients of Carer's Payment are women ${ }^{(1)}$ \\
\hline AUSTRIA & $\begin{array}{l}80 \% \text { of carers of persons receiving a Attendance } \\
\text { Allowance are women }\end{array}$ \\
\hline CANADA & not available \\
\hline FINLAND & $\begin{array}{l}80 \% \text { of carers of recipients of an Informal Carer's } \\
\text { Allowance are women }\end{array}$ \\
\hline FRANCE & $\begin{array}{l}99 \% \text { of those employed in the context of family } \\
\text { services (emplois familiaux) are women }\end{array}$ \\
\hline GERMANY & $97 \%$ of registered Informal Carers are women \\
\hline JAPAN & NA \\
\hline
\end{tabular}

Note: 1 Married women with an employed husband providing care are not eligible due to the means test. In addition, part of eligible Carers over 60-65 would be on an Age Pension 
Table 7. Payments for care-givers and labour market participation

\begin{tabular}{|c|c|c|}
\hline & $\begin{array}{c}\text { Impact on labour market incentives } \\
\text { (flexibility to leave work or opt for part time) }\end{array}$ & Link to employment policy \\
\hline AUSTRALIA & $\begin{array}{l}\text { It is possible to engage in up to } 20 \text { hours of paid or voluntary } \\
\text { work, education or training, while receiving the carer payment } \\
\text { but this may sometimes be difficult due to the needs for care. }\end{array}$ & none. \\
\hline AUSTRIA & $\begin{array}{l}\text { According to a survey, the attendance allowance allows } \\
\text { withdrawal from the labour force for } 9 \% \text { of all carers, and } 29 \% \\
\text { of those caring for someone at level } 7 \text {. The attendance allowance } \\
\text { enabled a reduction in hours worked for } 10 \% \text { of all carers, but } \\
30 \% \text { of those caring at level } 7 \text {. }\end{array}$ & none \\
\hline CANADA & $\begin{array}{l}\text { As in Austria, those caring for someone receiving the benefit } \\
\text { participate less in employment, but cause and effect is hard to } \\
\text { determine - especially given income restrictions and the fact that } \\
\text { the payment is very little. }\end{array}$ & none or maybe \\
\hline FINLAND & NA & none \\
\hline FRANCE & $\begin{array}{l}\text { Possibly may encourage early retirement since the informal } \\
\text { carers are themselves elderly. In any case, labour force } \\
\text { participation above } 55 \text { is already low in France. }\end{array}$ & $\begin{array}{l}\text { There was a clear goal of using such } \\
\text { family service jobs to increase job } \\
\text { opportunities. }\end{array}$ \\
\hline GERMANY & $\begin{array}{l}\text { Many carers are at retirement age or beyond. Also encourages } \\
\text { some part-time labour force participation. }\end{array}$ & $\begin{array}{l}\text { Has an effect inducing part-time } \\
\text { employment for women previously } \\
\text { not in the labour force because a new } \\
\text { status was created. }\end{array}$ \\
\hline JAPAN & NA. & $\begin{array}{l}\text { Concern for lack of supply of care } \\
\text { manpower (Shinotsuka 1998). }\end{array}$ \\
\hline
\end{tabular}


Table 8. Impact of informal compensated care-giving activities on formal care markets

\begin{tabular}{|c|c|c|c|}
\hline & Prices of social services & $\begin{array}{l}\text { Cost cutting, substitution for formal } \\
\text { care services, precarious work }\end{array}$ & Rate of use of formal care \\
\hline AUSTRALIA & NA & NA & $\begin{array}{l}\text { Community Nursing is available but } \\
\text { not at the intensity of nursing } \\
\text { homes. Outside of institutions } \\
\text { formal care would generally be } \\
\text { confined to weekly or probably } \\
\text { daily visits. There is also home } \\
\text { help, meals on wheels and personal } \\
\text { care. }\end{array}$ \\
\hline AUSTRIA & $\begin{array}{l}\text { Prices for provincially } \\
\text { provided social services rose } \\
\text { with the introduction of the } \\
\text { federally funded Allowance }\end{array}$ & $\begin{array}{l}\text { Demand for social services initially fell, but it } \\
\text { now seems to be rising. } \\
\text { Studies of some provinces found the existing } \\
\text { supply of home care, provided by the } \\
\text { voluntary sector was undermined. Agencies } \\
\text { requested payment from recipients of } \\
\text { Allowances, who were reluctant to pay for } \\
\text { something they had been receiving for free. } \\
\text { Non-profit agencies had difficulty sustaining } \\
\text { themselves }\end{array}$ & $\begin{array}{l}57 \% \text { of recipients purchase services } \\
\text { on a regular basis }\end{array}$ \\
\hline CANADA & $\begin{array}{l}\text { No apparent effect. } \\
\text { Some negative effect on wage } \\
\text { rates of formal carers noted }\end{array}$ & $\begin{array}{l}\text { Informal being substituted for formal. } \\
\text { Multi-tasks formal being substituted for more } \\
\text { skilled formal. } \\
\text { Informal carers being given responsibility for } \\
\text { increasingly complex medical care - i.e., this } \\
\text { is a "deprofessionalisation" of caring. }\end{array}$ & $\begin{array}{l}\text { Formal and informal are } \\
\text { complements }\end{array}$ \\
\hline FINLAND & NA & $\begin{array}{l}\text { Both the ICA and Pensioner's Allowance are } \\
\text { small programmes, with stable participation. } \\
\text { These care benefits have been accompanied } \\
\text { by a new job status, which carries some rights } \\
\text { and recognition. However, the proportion of } \\
\text { older people receiving home help has fallen, } \\
\text { due to public finance constraints. }\end{array}$ & NA \\
\hline FRANCE & $\begin{array}{l}\text { Lowered the average prices of } \\
\text { social services, due to the } \\
\text { competitive pressure of low } \\
\text { paid work. }\end{array}$ & $\begin{array}{l}\text { There has been some substitution of more } \\
\text { precarious, less well paid home care jobs for } \\
\text { "good" home care jobs, organised by formal } \\
\text { care service associations. There is a reduction } \\
\text { in black market work, but the jobs are poorly } \\
\text { qualified and low paying. There has been } \\
\text { some loss of employment benefits (and } \\
\text { therefore precarious) associated with the } \\
\text { incentive structure of the PSD. }\end{array}$ & $\begin{array}{l}\text { Formal care still used widely - by } \\
\text { purchasing services, but at a lower } \\
\text { cost. }\end{array}$ \\
\hline GERMANY & NA & $\begin{array}{l}\text { A dual effect: } \\
1 \text { - A new job status - registered informal } \\
\text { carer - has been created, with rights and } \\
\text { recognition, but also a marginal status in the } \\
\text { field of elderly care. } \\
2 \text { - Training for professionals has been } \\
\text { improved, and there seems to been an } \\
\text { increase in their numbers. } \\
\text { Therefore, there is both an increase of } \\
\text { professionalism (formal, professional carers) } \\
\text { and an increase of precarious work } \\
\text { (pflegepersons) }\end{array}$ & $\begin{array}{l}35-40 \% \text { of those eligible for } \\
\text { Payment for Care use some sort of } \\
\text { formal care (perhaps in combination } \\
\text { with informal care) }\end{array}$ \\
\hline
\end{tabular}

NA - not available 
Table 9. How is it paid? Labour market eligibility rules and amounts

\begin{tabular}{|c|c|c|c|}
\hline & $\begin{array}{c}\text { Eligibility rules with regard to } \\
\text { labour market }\end{array}$ & Amount per period & $\begin{array}{l}\text { Comparison with old } \\
\text { age public income } \\
\text { support }\end{array}$ \\
\hline $\begin{array}{l}\text { AUSTRALIA } \\
\text { Carer } \\
\text { Payment }\end{array}$ & $\begin{array}{l}\text { Recipients do not have access to } \\
\text { superannuating (pension) regime, } \\
\text { despite the Carer Payment being above } \\
\text { the minimum level that opens access. }\end{array}$ & $\begin{array}{l}\text { Flat rate } \$ 357.30^{(1)} \text { (231.7 Euro) } \\
\text { per fortnight for a single person. } \\
\text { ( } 714 \$ \text { a month, or } 462 \text { euros) } \\
\text { Flat-rate } \$ 298.10^{(1)}(193.3 \text { Euro) for } \\
\text { a member of a couple. } 596 \$ \text { a } \\
\text { month, or } 386 \text { euros) } \\
\text { These rates are close to } \\
\text { unemployment insurance minimum } \\
\text { (UI is also means tested) }\end{array}$ & $\begin{array}{l}\text { Age pension, single } \\
\text { person - } \$ 357.30(231.7 \\
\text { Euro) per fortnight; } \\
\text { member of a couple } \\
\$ 298.10 \text { (193.3 Euro })^{(1)} \\
\text { per fortnight }^{(1)}\end{array}$ \\
\hline $\begin{array}{l}\text { Carer } \\
\text { Allowance }\end{array}$ & $\begin{array}{l}\text { Labour force participation not } \\
\text { excluded, but may sometimes be } \\
\text { difficult due to care responsibility }\end{array}$ & $\begin{array}{l}\text { Equivalent to one-fifth of age } \\
\text { pension, } \$ 75.10 \text { ( } 48.7 \text { Euro) per } \\
\text { fortnight }\end{array}$ & \\
\hline $\begin{array}{l}\text { AUSTRIA } \\
\text { Attendant } \\
\text { Allowance }\end{array}$ & $\begin{array}{l}\text { Labour force participation not } \\
\text { restricted, either for Allowance } \\
\text { recipient or care providers }\end{array}$ & $\begin{array}{l}\text { Payments according to level of } \\
\text { dependency: } \\
\text { level 1=2,000 ATS (145.3 Euro) } \\
\text { level 7= 21,074 ATS, } \\
\text { (1,531.5 Euro) }\end{array}$ & $\begin{array}{l}\text { Single person : } 8,112 \\
\text { ATS, }(589.5 \text { Euro) } \\
\text { couple: } 11,574 \text { ATS } \\
\text { (841.1 Euro) }\end{array}$ \\
\hline $\begin{array}{l}\text { CANADA } \\
\text { Nova Scotia } \\
\text { Home Life } \\
\text { Support }\end{array}$ & $\begin{array}{l}\text { None - but income restrictions on care- } \\
\text { giver exist }\end{array}$ & $\$ 354$ (235.5 Euro) per annum & NA \\
\hline $\begin{array}{l}\text { Quebec } \\
\text { Respite Care } \\
\text { Allowance }\end{array}$ & $\begin{array}{l}\text { none - but usually only available to } \\
\text { carers with the heaviest } \\
\text { responsibilities, and therefore unlikely } \\
\text { to be in labour force }\end{array}$ & $\$ 600$ (400 Euros) per annum & NA \\
\hline $\begin{array}{l}\text { FINLAND } \\
\text { ICA }\end{array}$ & $\begin{array}{l}\text { none - depends on the contract } \\
\text { established between the municipality } \\
\text { and carer, which is set according to the } \\
\text { need of the recipient }\end{array}$ & $\begin{array}{l}1496 \text { FIM (1994) (251 euros) } \\
\text { range: } 250 \text { - 5,500 FIM (42 - } 925 \\
\text { Euro) }\end{array}$ & $\begin{array}{l}2,500 \text { FIM ( } 420.5 \text { Euro) } \\
\text { is minimum pension }\end{array}$ \\
\hline $\begin{array}{l}\text { Pensioners } \\
\text { Care } \\
\text { Allowance }\end{array}$ & NA & $\begin{array}{l}3 \text { levels: } 278 \text { FIM (46 Euros), } \\
\text { 691FIM (116.2 Euros), 1,382 FIM } \\
\text { (232.4 Euros) }\end{array}$ & ditto \\
\hline $\begin{array}{l}\text { FRANCE } \\
\text { PSD }\end{array}$ & $\begin{array}{l}\text { If the PSD is used to hire a family } \\
\text { member, that person must be } \\
\text { unemployed } \\
\text { The benefit may also be used to } \\
\text { purchase home care services or to pay } \\
\text { the cost of residential care }\end{array}$ & $\begin{array}{l}\text { Ceiling: 5,700 FF ( } 868.9 \text { Euro) per } \\
\text { month } \\
\text { average: } 3,200 \mathrm{FF} \text { ( } 487.8 \text { Euros) } \\
\text { payment varies by level of } \\
\text { dependency AND by income of the } \\
\text { recipient }\end{array}$ & $\begin{array}{l}\text { Average pension } \\
7,000 \mathrm{FF}(1067.1 \\
\text { Euros) per month }\end{array}$ \\
\hline $\begin{array}{l}\text { GERMANY } \\
\text { Domiciliary } \\
\text { Care Only }\end{array}$ & NA & $\begin{array}{l}\text { Monthly } \\
\text { level } 1400 \text { - } 750 \mathrm{DM} \\
\quad(204.5-383.5 \text { Euros }) \\
\text { level } 2800-1,800 \mathrm{DM} \\
\quad(409-920.3 \text { Euros }) \\
\text { level } 31,300-2,800 \mathrm{DM} \\
\quad(664.7 \text { - 1,431.6 Euros) } \\
\text { The higher amounts are available if } \\
\text { the payment is used to purchase } \\
\text { formal services }\end{array}$ & $\begin{array}{l}\text { No basic pension. } \\
\text { However, an elderly } \\
\text { person on social } \\
\text { assistance would } \\
\text { receive approximately } \\
1,200 \mathrm{DM} \text { in allowance, } \\
\text { housing and other } \\
\text { benefits }\end{array}$ \\
\hline
\end{tabular}


DEELSA/ELSA/WD(2000)2

Table 10. Forms of payment for informal caring work provided by payment for care

\begin{tabular}{|c|c|c|c|}
\hline & Short-term monetary compensation & $\begin{array}{l}\text { Long term compensations } \\
\text { (pension or other derived social rights) }\end{array}$ & $\begin{array}{l}\text { Other forms of compensation } \\
\text { (respite care, support for labour market } \\
\text { return) }\end{array}$ \\
\hline AUSTRALIA & YES & $\begin{array}{l}\text { NO - recipients of Carer's Payment not } \\
\text { included in superannuation, despite the fact } \\
\text { that level of benefit is higher than low income } \\
\text { cut off }\end{array}$ & $\begin{array}{l}\text { Respite care available through the HACC, } \\
\text { which is the broad umbrella programme for the } \\
\text { Carer's Payments and Carer's Allowance. } \\
\text { No support for labour market return. }\end{array}$ \\
\hline AUSTRIA & YES - recipients may choose to pay carers. & $\begin{array}{l}\text { YES - informal carers may opt into a pension } \\
\text { insurance scheme }\end{array}$ & $\begin{array}{l}\text { No respite care under this programme } \\
\text { No explicit support for labour market return but } \\
\text { general active labour market programmes } \\
\text { available }\end{array}$ \\
\hline CANADA & $\begin{array}{l}\text { YES - Benefits paid to care recipient who } \\
\text { may choose to pay informal carers }\end{array}$ & NO & $\begin{array}{l}\text { Respite care available in most jurisdictions; } \\
\text { varies by province and municipality } \\
\text { Access to home care services varies by } \\
\text { jurisdiction } \\
\text { No specific support for labour market return }\end{array}$ \\
\hline FINLAND & $\begin{array}{l}\text { - ICA : YES, this benefit is awarded to the } \\
\text { care recipient but paid to the carer, in a } \\
\text { contractual relationship with the } \\
\text { municipality } \\
\text { - Pensioner's Care Allowance: Partly, this } \\
\text { benefit may be used to pay a family } \\
\text { member or another person to provide care }\end{array}$ & $\begin{array}{l}\text { Individuals doing caring with an ICA have the } \\
\text { employment status "Carer of a relative" and } \\
\text { have access to basic occupational rights and } \\
\text { credits towards an occupational pension }\end{array}$ & $\begin{array}{l}\text { Municipalities are also required by law to } \\
\text { arrange for time off } \\
\text { Care recipients may also receive formal home } \\
\text { care and other services. } \\
\text { No specific support for labour market return, but } \\
\text { also not very applicable because most carers are } \\
\text { over } 65 \text {, on early retirement or unemployed }\end{array}$ \\
\hline FRANCE & $\begin{array}{l}\text { YES - Informal carers (excluding a spouse) } \\
\text { may be hired using the PSD. If a family } \\
\text { member is employed, he or she must be } \\
\text { unemployed. }\end{array}$ & $\begin{array}{l}\text { Informal carers hired with a PSD have access } \\
\text { to basic occupational rights. }\end{array}$ & $\begin{array}{l}\text { Availability of respite care dependent on the } \\
\text { jurisdiction. } \\
\text { No specific support for labour market return }\end{array}$ \\
\hline GERMANY & $\begin{array}{l}\text { YES - There are no legal restrictions on the } \\
\text { use of the Payment for Care, unless levels } \\
\text { of payment are lower if the cash option is } \\
\text { chosen }\end{array}$ & $\begin{array}{l}\text { The Payment for Care covers the cost of the } \\
\text { carer's contribution to age pension regimes if } \\
\text { the carer is employed less than } 30 \text { hours (in } \\
\text { another job) and cares for at least } 14 \text { hours a } \\
\text { week. Carers are covered by municipal } \\
\text { accident insurance. }\end{array}$ & $\begin{array}{l}\text { Respite care must be provided to a maximum of } \\
4 \text { weeks a year, including in S-T or other } \\
\text { residential institutions. } \\
\text { No specific support for labour market return, but } \\
\text { Care Insurance Funds are obliged to offer } \\
\text { training to carers }\end{array}$ \\
\hline
\end{tabular}


Table 11. How is it used? Patterns of use of benefits

\begin{tabular}{|c|c|}
\hline & Patterns of use \\
\hline $\begin{array}{l}\text { AUSTRALIA } \\
\text { Carer Payment }\end{array}$ & $\begin{array}{l}59.9 \% \text { of recipients of the Carer Payment are women and } 40.1 \\
\% \text { men. } \\
\text { The relatively high percentage of men reflects the structure of } \\
\text { the social security system, in which women doing caring for a } \\
\text { spouse will probably receive benefits as their husband's } \\
\text { dependent. (Women carers with employed spouses are not } \\
\text { eligible and older carers ( } 60-65) \text { have the choice to be on the } \\
\text { Age Pension). }\end{array}$ \\
\hline Carer Allowance & $\begin{array}{l}\text { In } 1993,63 \% \text { of recipients of the Carer Allowance were } 70 \text { or } \\
\text { older }\end{array}$ \\
\hline $\begin{array}{l}\text { AUSTRIA } \\
\text { Attendance Allowance }\end{array}$ & $\begin{array}{l}\text { Of those caring for recipient of an Attendance Allowance } \\
1.2 \% \text { have a formal contract } \\
25 \% \text { receive pay regularly } \\
23 \% \text { receive pay irregularly } \\
33 \% \text { have no explicit arrangement } \\
14 \% \text { receive no money }\end{array}$ \\
\hline $\begin{array}{l}\text { CANADA } \\
\text { Nova Scotia programme } \\
\text { Quebec self-managed } \\
\text { care } \\
\text { Quebec respite care } \\
\text { allowance }\end{array}$ & $\begin{array}{l}\text { NA } \\
\text { NA } \\
\text { Can be combined with public home care and other social } \\
\text { services }\end{array}$ \\
\hline $\begin{array}{l}\text { FINLAND } \\
\text { Informal Carer's } \\
\text { Allowance } \\
\text { Pensioner's Allowance }\end{array}$ & $\begin{array}{l}\text { Both can be claimed in conjunction with home care services and } \\
\text { other social services as well as each other - i.e., an individual } \\
\text { may receive: ICA, Pensioner's Care Allowance, home help, } \\
\text { respite care, etc. }\end{array}$ \\
\hline $\begin{array}{l}\text { FRANCE } \\
\text { Prestation spécifique } \\
\text { dépendance }\end{array}$ & $\begin{array}{l}\text { From an experimental assessment, patterns of hourly use: } \\
38 \% \text { hired an employee at home } \\
31 \% \text { contracted with an employment service } \\
22 \% \text { paid a family member } \\
9 \% \text { used for housekeeping help }\end{array}$ \\
\hline GERMANY & $\begin{array}{l}\text { The home care option is taken by } 71 \% \text { of recipients. } \\
\text { Of these, the overwhelmingly majority of those recipients took } \\
\text { cash, with the rest taking combinations of cash or services or the } \\
\text { domiciliary care package } \\
\text { Spending was highest, however, on the institutional care benefit, } \\
\text { because it is paid at the highest rate. }\end{array}$ \\
\hline
\end{tabular}

NA - not available 
Table 12. Summary Evaluation of the impact of care allowances

\begin{tabular}{|c|c|c|c|c|}
\hline & $\begin{array}{c}\text { Incentive } \\
\text { structure altered } \\
\text { so as to reduce } \\
\text { employment }\end{array}$ & $\begin{array}{c}\text { Short-term } \\
\text { compensation } \\
\text { provided to } \\
\text { women doing care } \\
\text { work informally }\end{array}$ & $\begin{array}{c}\text { Long-term } \\
\text { compensation } \\
\text { provided to } \\
\text { women doing } \\
\text { care work } \\
\text { informally }\end{array}$ & $\begin{array}{l}\text { Impact on the } \\
\text { labour market } \\
\text { of formal care } \\
\text { work }\end{array}$ \\
\hline $\begin{array}{l}\text { AUSTRALIA } \\
\text { Carer's Payment; } \\
\text { Carer's Allowance }\end{array}$ & No & $\begin{array}{l}\text { Yes - but maximum is } \\
\text { at means-tested } \\
\text { minimum }\end{array}$ & $\begin{array}{l}\text { No - carers are } \\
\text { excluded from the } \\
\text { superannuation } \\
\text { regime }\end{array}$ & NA \\
\hline $\begin{array}{l}\text { AUSTRIA } \\
\text { Attendance } \\
\text { Allowance }\end{array}$ & $\begin{array}{l}\text { No, except for those } \\
\text { caring for the most } \\
\text { frail, who receive } \\
\text { the highest benefit }\end{array}$ & $\begin{array}{l}\text { At the discretion of } \\
\text { the recipient; little } \\
\text { evidence of formal } \\
\text { payments to informal } \\
\text { carers }\end{array}$ & $\begin{array}{l}\text { Informal carers may } \\
\text { opt into a pension } \\
\text { insurance scheme }\end{array}$ & $\begin{array}{l}\text { Some initial } \\
\text { reduction of the use } \\
\text { of formal services }\end{array}$ \\
\hline $\begin{array}{l}\text { CANADA } \\
\text { Caregiver Tax } \\
\text { Credit }\end{array}$ & No & $\begin{array}{l}\text { Yes, but token and } \\
\text { targeted for low- } \\
\text { income carers }\end{array}$ & No & $\begin{array}{l}\text { Some } \\
\text { encouragement of } \\
\text { informal carers to } \\
\text { take over more } \\
\text { activities of formal, } \\
\text { including medical, } \\
\text { home care workers }\end{array}$ \\
\hline $\begin{array}{l}\text { FINLAND } \\
\text { Home Care } \\
\text { Allowance }\end{array}$ & No & $\begin{array}{l}\text { Yes, but some } \\
\text { municipalities are } \\
\text { eliminating benefits } \\
\text { to carers of retirement } \\
\text { age }\end{array}$ & $\begin{array}{l}\text { yes - if they work } \\
\text { enough hours, } \\
\text { carers may join a } \\
\text { municipal pension } \\
\text { regime }\end{array}$ & $\begin{array}{l}\text { Some substitution } \\
\text { of formal to } \\
\text { informal care may } \\
\text { be occurring }\end{array}$ \\
\hline $\begin{array}{l}\text { FRANCE } \\
\text { Prestation } \\
\text { spécifique } \\
\text { dépendance (PSD) }\end{array}$ & No & $\begin{array}{l}\text { Yes, except for } \\
\text { spouses. Any family } \\
\text { member hired must } \\
\text { be unemployed }\end{array}$ & $\begin{array}{l}\text { Yes, carers may pay } \\
\text { into the pension } \\
\text { regime }\end{array}$ & $\begin{array}{l}\text { Some reduction of } \\
\text { formal services } \\
\text { occurred }\end{array}$ \\
\hline $\begin{array}{l}\text { GERMANY } \\
\text { Long-term Care } \\
\text { Insurance }\end{array}$ & $\begin{array}{l}\text { No incentive to } \\
\text { reduce, but some } \\
\text { incentive to } \\
\text { increase, by } \\
\text { becoming a } \\
\text { Registered Informal } \\
\text { Carer }\end{array}$ & $\begin{array}{l}\text { At the discretion of } \\
\text { the recipient; little } \\
\text { evidence of payments } \\
\text { to informal carers }\end{array}$ & $\begin{array}{l}\text { Yes, informal carers } \\
\text { may register, and } \\
\text { thereby gain access } \\
\text { to pension and } \\
\text { accident insurance }\end{array}$ & $\begin{array}{l}\text { Some increase of } \\
\text { formal employment } \\
\text { has occurred }\end{array}$ \\
\hline $\begin{array}{l}\text { JAPAN } \\
\text { home care services }\end{array}$ & No & No & No & Yes \\
\hline
\end{tabular}


Table 13. Support desired by care-givers

\begin{tabular}{|c|c|c|c|c|}
\hline & More cash & Respite care & $\begin{array}{c}\text { Counselling, Training and } \\
\text { support }\end{array}$ & Flexible, friendly work arrangement \\
\hline AUSTRALIA & NA & $\begin{array}{l}\text { Carers identify respite care as the } \\
\text { single most important service } \\
\text { provided by the Home and } \\
\text { Community Care Programme } \\
\text { (HACC). Identified as a need by } \\
16 \% \text { of carers. (ABS 1998) }\end{array}$ & $\begin{array}{l}\text { Counselling, training and } \\
\text { support identified as an } \\
\text { important support for caregivers } \\
\text { in a range of studies }{ }^{(1) .}\end{array}$ & $\begin{array}{l}\text { As } 51 \% \text { of all carers work full-time, } \\
82 \% \text { of them hope to change their } \\
\text { participation in the workforce }\end{array}$ \\
\hline AUSTRIA & NA & In a survey, respite care mentioned & NA & NA \\
\hline CANADA & $\begin{array}{l}\text { Financial compensation would } \\
\text { help continue caregiving for } 14 \\
\% \text { of women and } 16 \% \text { of men. } \\
\text { The persons desiring financial } \\
\text { compensation were younger, } \\
\text { women, married and with lower } \\
\text { income. They had incurred } \\
\text { expenses as a result of } \\
\text { caregiving. }\end{array}$ & $\begin{array}{l}\text { Respite care was mentioned as useful } \\
\text { to continue caregiving by } 16 \% \text { of } \\
\text { caregivers of both genders. }\end{array}$ & $\begin{array}{l}\text { Counselling was mentioned by } \\
5 \% \text { of caregivers. } \\
\text { Information was mentioned by } \\
16 \% \text { of women and } 9 \% \text { of men. }\end{array}$ & $\begin{array}{l}12 \% \text { of women and } 11 \% \text { of men } \\
\text { mentioned flexible work/study. }\end{array}$ \\
\hline GERMANY & $\begin{array}{l}\text { Improved facilities in their } \\
\text { home }\end{array}$ & NA & Counselling & NA \\
\hline JAPAN & $\begin{array}{l}19 \% \text { of caregivers desired an } \\
\text { increase in care benefits in } 1987 \\
\text { and } 22 \% \text { in } 1997 .\end{array}$ & $\begin{array}{l}39 \% \text { of caregivers desired institutions } \\
\text { allowing semi-long stays in } 1987 \text { and } \\
51 \% \text { in } 1997 .\end{array}$ & $\begin{array}{l}12 \% \text { of caregivers desired } \\
\text { counselling in } 1987 \text { and } 1997 . \\
22 \% \text { of caregivers desired } \\
\text { training in } 1987 \text { and } 15 \% \text { in } \\
1997 . \text { Around } 30 \% \text { of } \\
\text { caregivers desired a support } \\
\text { group both in } 1987 \text { and } 1997 .\end{array}$ & NA \\
\hline
\end{tabular}

No data were available for France and Finland.

NA - not available 
Chart 1. Women's participation rates in the labour market by age groups
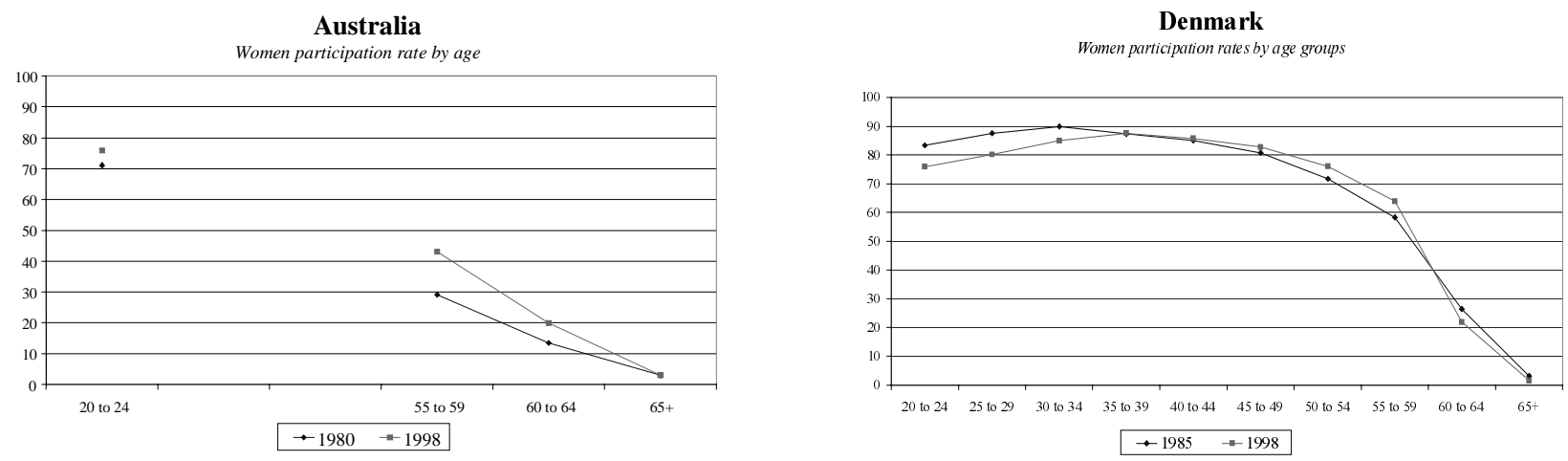

Austria

Women participation rates by age groups

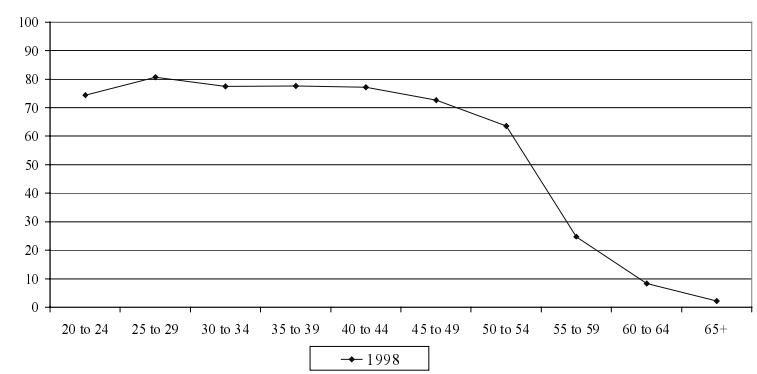

Finland

Women participation rate by age group

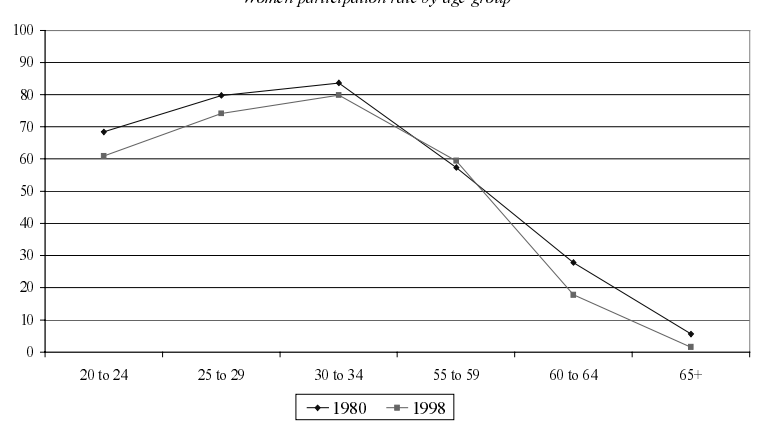

Belgium

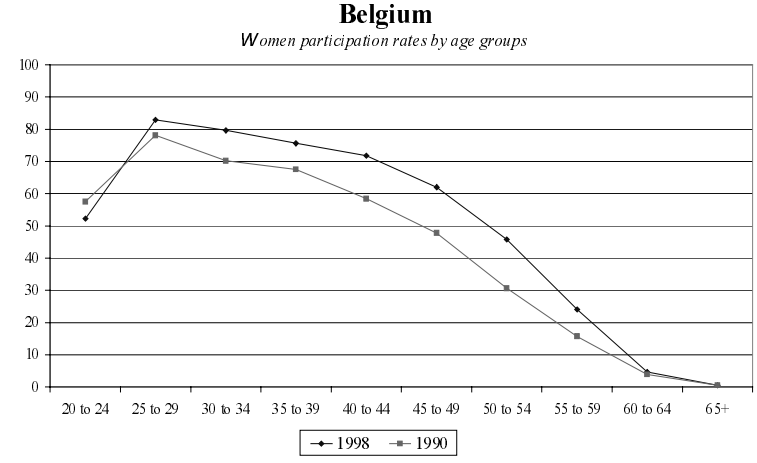

France

Women participation rates by age groups

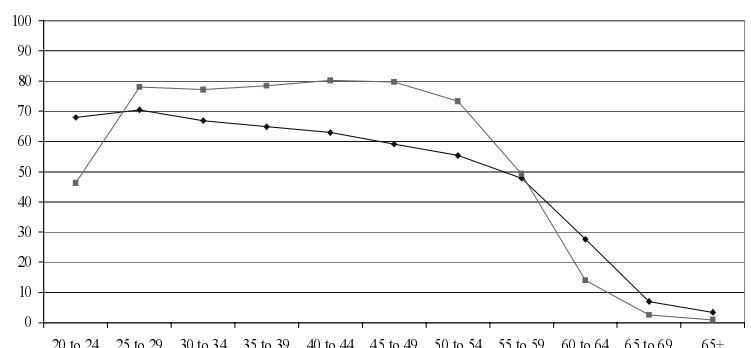

$\rightarrow 1980 \quad-1998$

Canada

Women Participation rates by age groups

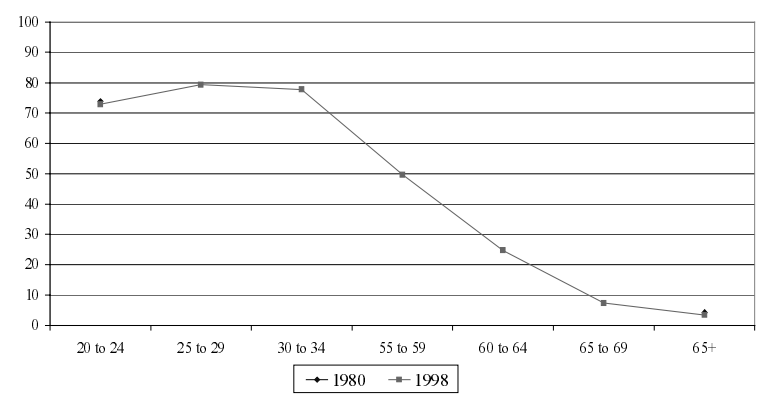

Germany

women participation rates by age groups

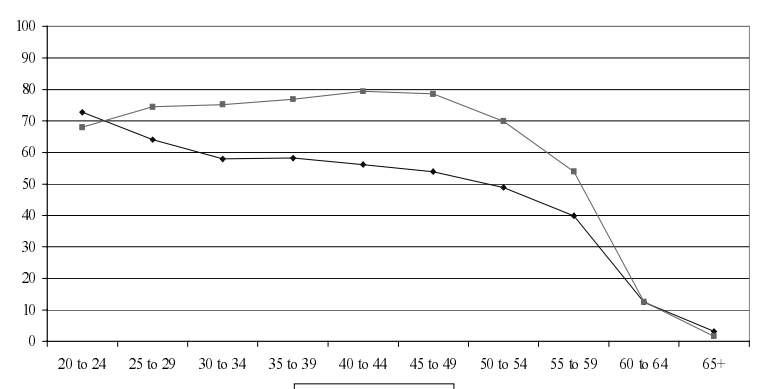

$\rightarrow 1980 \rightarrow-1998$ 
Italy

Women participation rates by age groups

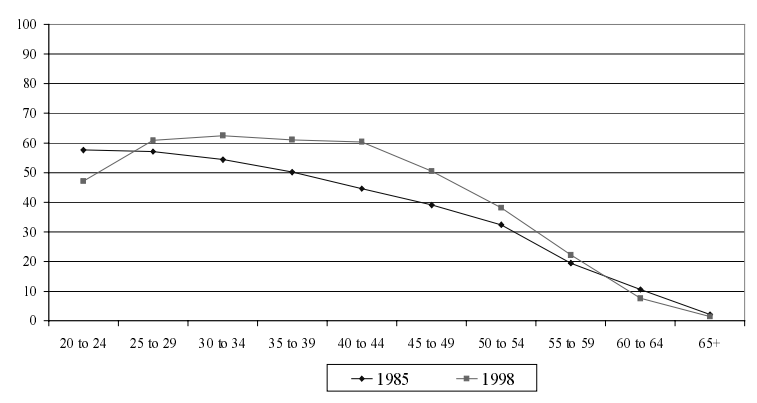

Japan

Women participation rates by age groups

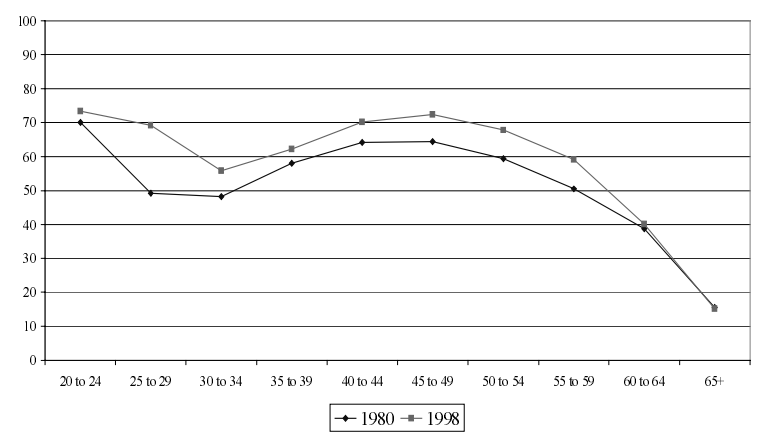

Luxembourg

Women participation rates by age groups

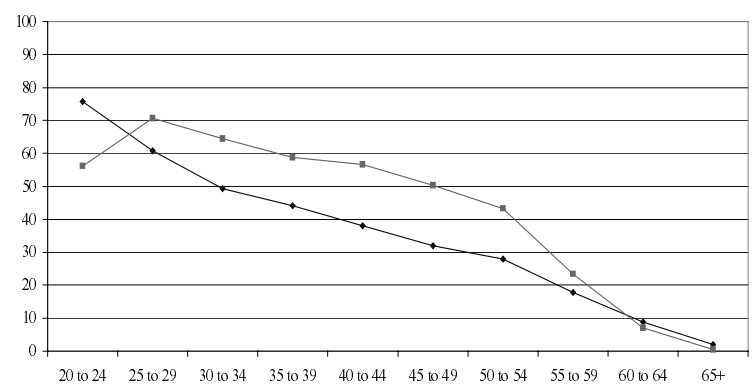

$\rightarrow 1985 \rightarrow 1998$

Netherlands

Women participation rates by age groups

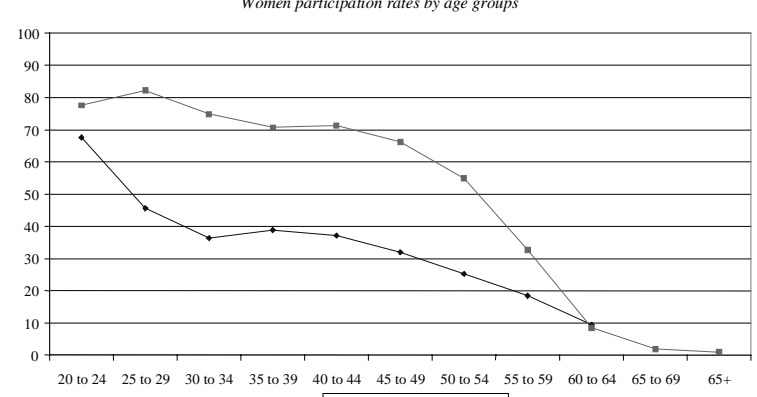

$\rightarrow 1980 \rightarrow 1998$
Norway

Women participation rates by age groups

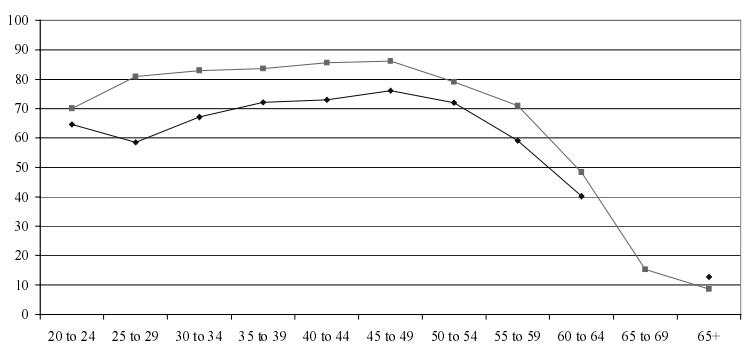

$\rightarrow-1980 \quad \rightarrow-1998$

Spain

Women participation rates by age groups

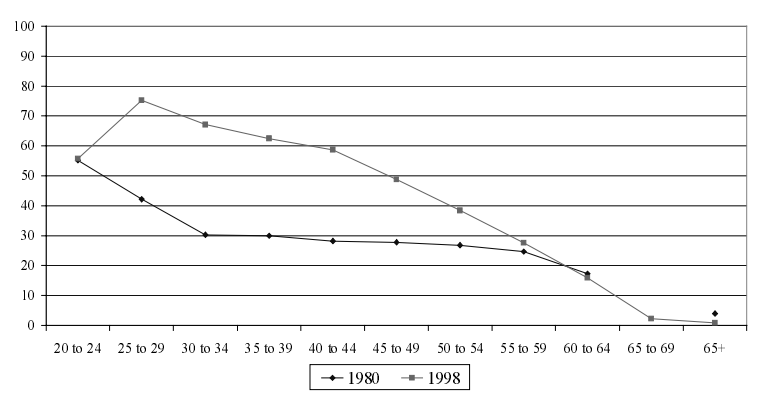

United Kingdom Women paticipation rates by age groups

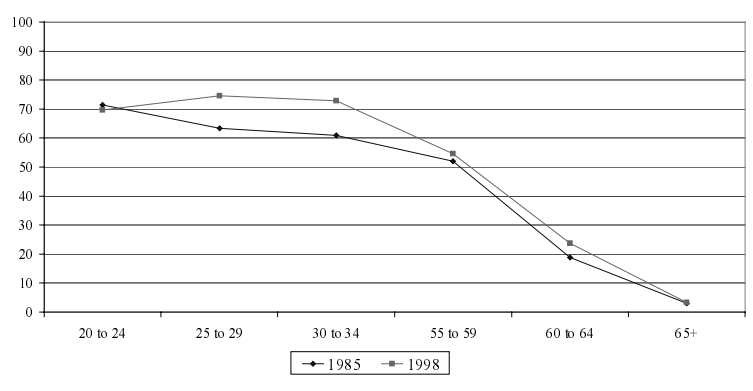

United States

Women participation rates by age groups

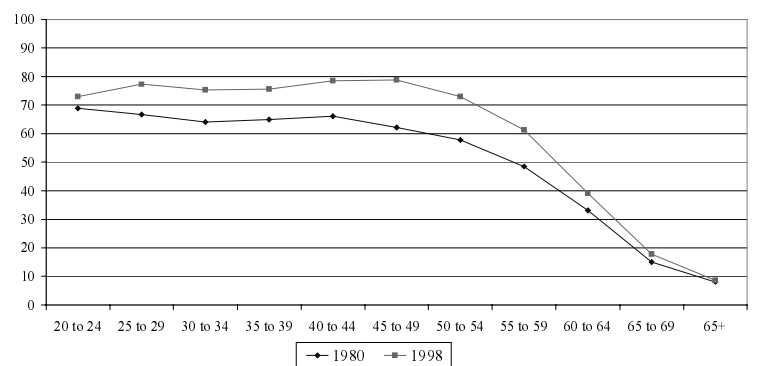

Source: OECD, Labour Force Statistics 


\section{ANNEX \\ COUNTRY PROFILES}

\section{Australia}

\section{Description of developments in the Policy Regime}

\section{The Australian old age welfare system}

128. Historically, services for frail and destitute elderly people without family support were the province of charitable agencies. The Federal government did not enter the field until 1954. Policy developments in the following three decades were oriented toward residential rather than home based services, resulting in a system characterised by a chronic over-reliance on nursing home beds and inadequately developed community-care sector.

129. In the area of aged care policy, Australia has a three tiered system of aged care - nursing homes, hostels and a range of services which support people living in the community. The Commonwealth Government has the primary responsibility for funding residential aged care (nursing homes and hostels) and provides most of the funding for the Home and Community Care program which is cost-shared with State/Territory governments.

130. State and Territory governments provide the remainder of Home and Community Care program funding, the funding for some residential aged care services, and some operational funding, actual or inkind, for assessment services. In addition, the charitable sector provides a substantial non-monetary contribution through the active participation of a large volunteer labour force.

\section{Rationalising the provision of aged care services, from institutional to community care}

131. In 1982, an inquiry by the Federal House of Representatives Standing Committee on Expenditure recommended that the entire system of aged care support be overhauled and more domiciliary care services be provided to enable people to remain in their own homes. This represented a clear shift in policy direction away from institutional care for the aged to an increasing emphasis on care provided in the home.

132. The changes following from 1983 to 1985 came to be known as the Aged Care Reform Strategy. The objectives of this strategy were the reform of both community and residential care, and the implementation of appropriate assessment strategies to establish links between the various sectors of provision. The new strategy had three key elements:

- need assessment 
- restrictions on the provision and use of residential care in nursing homes

- expanded system of community support.

Most notable among the changes was the introduction of the Home and Community Care (HACC) Program in 1985. The explicit aim of this program was to maintain people in their own homes wherever possible and to shift expenditure in favour of community care. The legislative recognition of carers in the HACC Act 1985 was an important acknowledgement of the role of carers and provided direct support through respite care, information, education, training and counselling directed to their specific needs.

133. The outcome of the policy shift since the mid-1980s is evident in a gradual shift in expenditure patterns in favour of community care. From 1985 to 1994, combined Federal and State government expenditure on home based care increased in real terms by 134 per cent, with the HACC program increasing its share of expenditure on aged care from 15 per cent to 22 per cent over the same period.

134. More recently a recent shift in aged care provision has been implemented to limit the use of residential care in nursing home, with a substantial move towards increased cost-sharing for nursing home care. This has been accompanied by various subsidies and programs to help develop community care.

135. Residential care is offered by nursing homes (higher dependency residents) and hostels (lower dependency residents). The funding and service delivery arrangements are however quite complex. This is the result of a federal system, and a pattern of development that relied heavily on the non-government sector. The result is a system of services for frail elderly people provided by a complicated interaction of Federal, State and local governments, the voluntary or charitable sector, and the private-for-profit sector, further supported by the unpaid labour of family and friends.

136. Private (for profit) organisations provide 47 per cent of nursing home beds and 2 per cent of hostel places; not-for-profit organisations provide 37 per cent of nursing home beds and 92 per cent of hostel places. State governments provide 16 per cent of nursing home beds and 6 per cent of hostel places. For nursing homes, about 75 per cent of funding is granted by the Commonwealth with the remainder coming from resident charges. Hostels receive less than half of their funding by way of Commonwealth subsidy.

\section{Socio-Economic and Demographic Changes}

137. On the whole, the ageing phenomenon will be less pronounced in Australia than in other OECD countries. Projections of the population of Australia from 1976 to 2006, show that annual rates of increase for the period are significantly higher for the old than for the young, and women represent the majority of the old. Australian women have an average life expectancy at birth of 80 years, six years longer than the average for Australian men, although the difference in life expectancy is lower at the age of 65. The group aged 80 and over is expected to have the highest growth. Furthermore, in Australia the proportion of elderly people living alone has increased from $15 \%$ in 1970 to over $20 \%$ in 1991 . The majority of unpaid carers are women, partners, daughters or daughters-in-law (67\%). Spouses are the single largest category of carers of frail and disabled older people. $61.5 \%$ of carers were over the age of 40 . Of these, $32.5 \%$ were aged 45-59 and 29 per cent aged 60 and over. $27.9 \%$ of carers were looking after a parent, while $42.3 \%$ were caring for a partner (ABS 1995). Family carers provide the vast majority of care to those who are unable to manage alone. A 1993 ABS survey estimated that of the three million persons with a disability living in the community, just under half needed help with one or more activities associated with daily living. Carers supplied the vast majority of this support, providing around $75 \%$ of the needed help. 
Community services provided formal support for a further $10 \%$ and privately arranged/commercially provided services for $7 \%$.

138. As the population ages, the increased demand for carers will occur at the same time as the impact of other social and economic changes, especially changes in the organisation of work and family life. These carers are likely to be primarily recruited both among the 45-65 age group, still on the labour market and also among groups aged 65 and over due to the lengthening in life expectancy and the need for care very late in life. One of the most significant of these changes as outlined above, is the increased participation of women in paid employment. Women's labour force participation has increased steadily over the years from 44 per cent in 1981 to 53 per cent in 1998. The trends indicate an increasing rate of labour force involvement for women in the $45-54$ age cohort compared with a generally more stable pattern for older men. By 2011, 46 per cent of women in there fifties will be in the workforce compared with 29 per cent in 1980, as it is expected that these new cohorts will have greater attachment to the labour force.

\section{Austria}

\section{Description of developments in the Policy Regime}

\section{The Austrian old age welfare system}

139. The Austrian welfare system is a Bismarkian insurance-based system. Inclusion is acquired through individual contributions, as in Germany. Non-employed persons might either derive their legal right to benefits from an employed relative or pay "voluntary" contributions in order to secure their own right to benefits. Prior to the Attendance allowance program, care of the elderly in Austria was provided either by residential homes or by the family of the person in need of care. While only 3 to 4 per cent of the frail elderly over 60 years were living in residential care arrangements, the bulk of care work was rather done by informal carers - mainly women. Public involvement in care issues was mainly confined to residential care.

\section{Extending Social Policy Coverage, the Attendance Allowance}

140. Care issues, as the responsibility of the provincial governments, were treated differently throughout the nine Austrian provinces and, as a result, a variety of benefits and entitlements existed throughout the country. This situation of inequality among Austrian residents was aggravated by the fact that, in addition to region-specific regulations, entitlement to benefits also differentiated between both the various social insurance bodies - and therefore the respective (former) profession of the recipient - as well as causes of the handicap. There was only one universal benefit: the "Hilflosenzuschuß" for the very disabled older persons. Furthermore, social service structures were strongly fragmented. Access to home services depended on the place of residence. While in some provinces home services coverage reached almost 100 per cent, in other provinces such facilities remained severely underdeveloped.

141. From the early 1990s onwards, efforts were made to achieve a uniform, nation wide regulation. In one Vorarlberg, an attendance allowance programme was already being implemented (Badelt, Österle 1994). In 1993, the federal authorities adopted as a nation-wide attendance allowance program.

142. The attendance allowance is granted to everyone in need, irrespective of the reason of their handicap, and is paid out to the person in need of care. The benefit is not means-tested and is not part of 
the insurance-based social security system. This is a major difference from the German system, however, the structure of the two welfare systems are rather similar. According to the Attendance Allowance Act, the benefit is intended to cover part of the extra costs arising from care needs. The benefit is a cash payment; there is no choice between cash or services in kind. It is to enable recipients of the attendance allowance to purchase care services from whomever they wish. In principle, the recipient is free to choose how to use the money; there are no restrictions, except in the case of residential care or obvious neglect of the recipient, in which case the cash benefit is replaced by benefits in kind.

\section{Socio-economic and Demographic Changes}

143. Austria is experiencing rapid population ageing. The 65 years age group will increase by one third in the next twenty-five years and the number of those over 85 will double. In Austria, only 5-10\% of the elderly are receiving social services and are in nursing homes. Family members and relatives provide care for more than a majority of the elderly. $80 \%$ of the informal care- givers are female. According to the survey, men tend to take on informal care duties only after retirement.

144. Socio-economic changes in Austria have led to a slight increase in female employment. In 1998, women participation rate in the labour force was about $60 \%$ from $57 \%$ in 1981(see chart). Other demographic changes include higher rates of divorce and single-person households (Federal Ministry of Labour and Social Affairs, 1994)

\section{Canada}

\section{Description of developments in the Policy Regime}

\section{Background on Canada's old age welfare system}

145. In Canada, the Federal government, 10 provincial and two (soon to be three) territorial governments, and countless municipal/county/regional governmental bodies share the responsibility for policies affecting caregivers and care receivers. Authority in some areas is clearly defined and designated to one level of government, while in other areas there are overlapping jurisdictions. The latter is the case with health and continuing care policy, under which care benefit programs would fall. The provinces and territories have joint statutory agreements with the Federal government on taxation, equalisation payments and funding of major social programs (Doern \& Phidd, 1992), but have jurisdiction over the development, administration and delivery of specific programs.

146. The provinces and territories have the power to legislate in the areas of health and social services. In order to receive funding, provinces must adhere to principals of the Canada Health Act. If the provinces do not comply, federal transfer payments can be reduced or withheld (Stryckman \& Nahmiash, 1994). The major policy instrument used by the Federal government to fund provincial health and social services is the conditional grant or block funding which involves a tax transfer and cash payment (Stryckman \& Nahmiash, 1994).

\section{Regionalisation of Health Care Service Delivery}

147. Recent years have brought devolution of responsibility for the delivery of health and continuing care services from provincial governments to Regional Health Authorities (RHAs). Funding is transferred, 
according to complicated formulae, from the provincial government to these RHAs who then have the authority to decide how to allocate those funds within their respective regions. RHA boards are elected in some provinces, appointed by the provincial government in others. These complex arrangements run the risk of blurring responsibilities for quality of care across provinces. In addition, they may also generate discrepancies in access to care and quality of services across regions, even within a given province.

\section{A Pull towards privatisation}

148. Another trend in the Canadian health and continuing care sectors has been a pull toward privatisation and the possible emergence of a two-tiered health care system. Canada has long been proud of its universal health insurance system that ensures basic medical and hospital care to everyone. This system is under pressure, however, due in large part to general public financial constraints. There is a concern that an ageing population may result in additional public expenditures on health and social programs thus intensifying budgetary problems. In 1996, public sector funding was $69.9 \%$ of total health expenditure, a decrease from $74.6 \%$ in 1991 . At the same time, private sector funding rose to $30.1 \%$ in 1996 and has been increasing annually by $0.5 \%$.

149. The result has been a wide variety of measures intended to contain the public costs of providing health, continuing care and other social services. These include de-listing of selected services (for example, eye exams in Alberta), de-institutionalisation (for example, closing of mental health and long term care facilities), earlier discharges from critical care institutions, increased use of out-patient treatment, and licensing of private health care facilities. Furthermore, health services provided at home are not covered under the general health care system. Observers have labelled such measures as "passive privatisation."

150. This naturally has wide-reaching implications for Canadian health care consumers. It also has serious implications for informal caregivers since the burden of caring is shifted from the institutional setting towards Home and Community Care. Older people may prefer to stay at home for several reasons, including a desire for autonomy and privacy. However, in the absence of adequate formal support within the community the growing "care gap" has to be filled by informal caregivers.

\section{Shift from Institutional to Community Care}

151. The above also is consistent with an increasing emphasis on community over institutional care, which may be justified on several grounds. However, this may in include a concomitant shifting of responsibility for care from the formal to the informal sector. Community care may appear by policymakers as "better" and "cheaper" than institutional care--better because informal caregivers are more aware of and responsive to the needs of seniors, cheaper because informal care is "free". Women constitute the majority of caregivers (Cohen, 1994). Hence, the shift of care from institutions to the community amounts to a downloading of responsibility to informal female caregivers.

\section{Socio-Economic and Demographic Changes}

152. Basic demographic trends have implications for informal caregivers. The proportion of older people in the Canadian population is increasing (Moore, Rosengerg \& McGuiness, 1997). The vast majority of Canadian seniors live in private households--92\% in 1991 (Statistics Canada, 1997). Even though this proportion declines with age, the majority of seniors of all ages remain outside of residential care settings throughout their lives. 
153. Women, the traditional caregivers, are increasingly participating in, and attached to, the labour market (Fast \& Skrypnek, 1994). In the last decade, female employment has increased significantly. Notably, women between the ages of 25 and 54 now have the highest employment rates at about $70 \%$ (Chart, 1998). Most of these women are mothers. The employment rate of women with children in the last decade has also increased dramatically. This means that their time has to be divided between work, family obligations, care-giving, and their personal interest and goals.

154. The above trends threaten the ability of the informal sector to meet the increased care needs of an ageing population. Women already find it increasingly difficult to balance the competing demands of paid and unpaid work. Nevertheless, the vast majority (80-90\%) of elder care is provided by informal caregivers (Chappell, 1992). In spite of their time care-giving responsibilities, most work outside the home and have families of their own.

\section{Finland}

\section{Description of developments in the Policy Regime}

\section{The Finnish model of old age welfare system}

155. In the Nordic countries, social care services have played a significant role in old age welfare. A feature of the Nordic old age welfare is the high rate of institutionalisation among the elderly (Noro 1998, 2). The Finnish old age welfare is based upon legislation dating back to the 1950s and giving priority to the development of institutional care. In the 1960s, the national home help system was expanded, and the 1970s saw a huge growth in community care services for elderly and disabled.

156. National as well as comparative studies show that the Nordic welfare state regimes, including Finland, have one of the most advanced systems for safeguarding citizen's social rights to social services, this is particularly true for areas such as children's day care and care for elderly (e.g. Anttonen \& Sipilä 1996). However, the Finnish economy faced a deep and serious crisis in the early 1990s. In a three year time period, between 1990-93, the GDP was reduced by 12 percent and the level of unemployment rose from 3.4 to 20 percent. ${ }^{15}$ Therefore, the government was faced with unprecedented public financial constraints; cutbacks were initiated in the budget and transfer payments reduced. As a result, local communes have had to decrease their services.

\section{Reconstructing Social Policy}

157. The Social Welfare Act of 1984 obliged municipalities to provide services according to need, but also gave them freedom to decide how these needs are met. It permitted the use of state subsidies for purchasing social services produced not only by the municipal authorities but also by voluntary and private organisations as well as payments for informal caring (following the Danish model).

158. Another major change took place in 1993 when the system of earmarked state subsidies for social welfare was reformed. In spite of these legal changes, social services continue to be financed by tax revenues, and only partly by users.

15. In 1997, unemployment rate was among women $13 \%$ and among men $12.3 \%$ (Statistics of Finland). 


\section{Shift from Institutional to Community care}

159. The proportion of elderly people living in institutions has been traditionally higher than in most other European countries. Originally, institutional care was part of the municipal poor relief system; however, in the 1950s poor elderly persons without family support were accompanied with more affluent elders as users of institutional care. Old age homes lost much of their poor house image and started to resemble hospitals for the deserving elderly rather than workhouses for the undeserving poor. In the beginning of the 1980's, institutional care was at its height.

160. In the 1990s, there were significant changes due to the deinstitutionalisation policy. From the early 1990s the reduction in places affected all age groups. Among the age group 85 or over the reduction in places has been between 1990-1996 $19 \%$ and among the age group 75-84 around 20\%. Long-term care in old age homes has been substituted for with service housing and to some extent by community care services.

\section{Home care services}

161. Since the 1970s, community care for the elderly has been developed by the building of service centres, offering a wide range of facilities: meals, laundry service, sauna, hairdressers' shops and chiropodists. They also serve as social clubs where elderly people can meet one another, and in many places dances are arranged. Finally, service centres also make house calls.

162. Against the background of declining institutional care, there has not been any significant increase in home help services. The service was expanding up until 1988, but after that year there has not been any growth. Moreover, service fees have gone up and the number of users has also increased.

163. As far as health care services are concerned, home nursing is an important part of community care. The basic principles of home nursing are similar to those of home help: these two services form the backbone of old age welfare for those living at home. Generally, elderly people have access to national health care that is either free of charge or strongly subsidised by the state and municipalities. However, long-term care has a different fee policy and home nursing is considered rather expensive even for those elderly people whose pensions are fairly good (see Vaarama \& Kautto 1998: 52-53).

\section{Socio-Economic and Demographic Changes-}

164. Finland is experiencing rapid population ageing. Moreover, an increasing number of elderly people are living alone and prefer to stay at home as long as possible. In Finland the share of women of elderly population is exceptionally high. While the number of elderly population is growing fast, the most rapid growth is taking place in the proportion of elderly and especially elderly women living alone. If the pension commitments can be managed, there still remains the question of who is going to do the increasing caring work.

165. Elderly care is a very female dominated area, only $7 \%$ in 1970 and $4 \%$ in 1990 in elderly care were male workers (ibid: 35 ). Women take care of elderly people and among elderly population women need more care then men do, since they live longer then them and more often live alone.

166. Women's full-time employment outside the home is higher in Finland than in any other western country. In 1986 only $11.4 \%$ of employed women were working part-time. In 1996 the corresponding figure was $15 \%$. Thus, women's integration into the male wage-labour society has been exceptionally intensive in Finland. In the early 1980s every third woman was working in the public sector, whereas in 
1997, $41 \%$ of employed women were working in the public sector. The feminisation of labour market has been parallel with the expansion of the welfare state.

167. Female wage employment outside the home has increased to the point that in the early $1980 \mathrm{~s}$ women represented about half of the active labour force (in $199747.7 \%$ ). In 1980, $69.3 \%$ of the female population aged 15-64 years belonged to active labour force. In 1995, the corresponding figure was 70,3\%. (Työvoimatilasto 1996, p. 50)

\section{France}

\section{Description of developments in the Policy Regime}

\section{The Welfare State in France}

168. The Laroque report in 1962 is generally considered as marking a turn in French policy towards the frail elderly, particularly by the priority accorded to home and community-care. At that time, the goal was to promote the integration of older persons in their environment, (mostly for the valid ones) and avoid their isolation. Some of the proposals of this report were slowly implemented during the 1970s (housing, leisure for older persons, house keeping services, but also medical institutions and special wards in hospitals).

169. Two laws from June 1975, one for handicapped persons, creating the "allocation compensatrice pour tierce personne" (ACTP), compensating benefit for a third person, the other for medical and social institutions, played a key role for developing the long-term care systems for the frail elderly. In 1978, long term stays and a shared pricing systems had been created, including a fixed amount for nursing care, to be paid by sickness funds, and a fixed amount for housing and food, to be paid by either the recipient of care, his or her children or social assistance. Experts and decision-makers began to speak about long-term care, or "persons who have lost their ability to perform essential activities of daily living". In 1981, the first Assistant Secretary for retired and older persons was created. In 1982, the Franceschi law, aimed at better co-ordinating the supply and the needs, as well as their adequacy with gerontological strategies, developed at the level of the "départements" (counties), with the contribution of the State and the local assemblies.

170. Long-term care began to be a specific question only from 1986 onwards, with the preparation of the Theo Braun report, and the National Committee for the study of frail older persons, whose goal was to analyse the causes of the phenomenon and the inadequacy of current answers. This report proposed a "long-term care insurance " for retired persons and the opening of a benefit in kind within the ACTP.

\section{The slow process of reform}

171. The ACTP mentioned above constituted one of the main schemes in charge of long-term care at home even if it was initially defined for handicapped middle aged persons. Many analysts identified two main problems and limits with the ACTP. First, the fact that benefits were distributed at a slow pace due to the screening process with the Commissions techniques d'orientation and reclassement professionel (COTOREP's). Second, these benefits were often paid with a lot of payments overdue. There was a suspicion that benefits were misused by the beneficiaries who were suspected of keeping the amounts in saving accounts instead of using them to finance the necessary services for their daily lives. The idea was therefore to create a specific benefit that could be distributed quickly, equal to the ACTP, means-tested, and adapted to the level of care needs (this presupposes a national grid to assess long-term care needs). 
There are differences whether a benefit in kind is proposed (Braun report), which is easier to control, or whether it is a benefit in cash (Schopflin report).

\section{The obstacles to reform}

172. Reforms faced a strong public finance constraint: it has been difficult to promote a policy, which is still difficult to assess in terms of its long-term financial consequences. Long-term care needs are difficult to define, as is disability. Therefore, it is difficult to assess the importance of the population of recipients that might be concerned. The second obstacle is less apparent as it is linked with the general orientations of the reform of social protection. Should long-term care be treated as a social risk within the framework of social insurance or as part of social assistance schemes with the protection of the most deprived persons with all the consequences in terms of operating and financing and also stigmatisation of the recipients concerned? Confronted with these difficult choices, the Balladur government had proposed to develop experiments or sites for a new scheme starting in January 1995. The terms of reference for these experiments had been defined by the State with leeway for initiative to local governments ("département") or the sickness and social security funds that were involved. Forty-one departments had volunteered to take part in these experiments and twelve had been selected in December 1994. The aim of these experiments was to test a scheme that was built by local governments before going to generalisations in a few sites.

173. The opportunity offered by this experiment was largely missed (Martin 1998). A long-term care law was voted in January 1997, which replaced the ACTP with the Prestation Spécifique Dépendance (PSD). Further legal text for enacting this law has been recently published. The few available information states clearly that implementing this new law posses serious problems, be it in terms of local co-operation, territorial equity, geographical equity or consequences for care-givers, especially professional women in charge of care-giving and members of the parenthood of the persons being helped. This type of a policy keeps France along the countries that leaves long-term care mainly in charge of the family, the state taking charge of the most deprived in the form of social assistance.

\section{The new scheme}

174. The PSD is a new social assistance benefit that can be awarded either in institutions or at home and replaces the compensating attendance allowance paid to older persons. The law included proposal for reforming the pricing system, which can be set for institutions for older persons. The proposal was to create a new status for frail elderly person depending on disability level and not on the legal status of the institutions. This can be either from the health sector, with the possibility of financing from the sickness insurance, or from the medical and social sector with financing from the social services.

175. The beneficiaries of the specific long-tem care attendance are frail persons age 60 and over legally residing in France regardless of citizenship. The law is not very explicit about the definition of disability. It is defined as the need of persons to have help with activities of daily living and self care requiring continuous monitoring. The law does not stipulate anything on the levels of disability, as these are defined by a decree (the AGGIR scale).

176. The means-test is identical to those of the former compensating benefit (ACTP). There is no necessity for support from spouses or children but there is a possibility to recover the money and the estate. The specific benefit for disability can be cumulated with the beneficiary's resources and also those of his spouse with the limit of 72000 French francs per annum for a single person and a 120,000 per annum for couple. Recovering the money and the estate of the recipient of the PSD can only be done for net assets over three hundred thousand francs. Only spending over five thousand francs can be recovered. 


\section{How the PSD is awarded}

177. The request has to be sent to the head of the local government (Conseil General of the département) where the person is living and must be examined by a medical and social team. The medical social team uses the AGGIR scale to assess the disability level of the person and sets a care plan that the person can refuse. The AGGIR scale allows classifying recipients in six groups with equivalent resources. In another word only persons in the most dependant levels, groups one to three, can be awarded the specific care benefit. Only those older persons heavily dependent will be helped.

178. A care plan set by the medical social team is estimated with the reference cost which is determined by the president of the Conseil Général, the local assembly for the different types of help. According to this plan the local assembly awards the benefits. There is a departmental maximum but no minimum.

179. The PSD at home has to be used to pay either for salaried person with the beneficiary's employee's or to pay for home care, which must be previously arranged, or by services given by a person taken by beneficiaries. Beneficiaries can employ one or several members of the family with the exception of a spouse or a partner. The specific benefit cannot be used to pay a person who already enjoys old age benefits. The specific benefits in institutions are paid directly to the institutions. The beneficiary has to show that it has received help in order for the benefit to be paid. The benefit is paid in kind justifying papers to show the costs generated by the lack of autonomy.

\section{The disadvantages of the PSD}

180. The old system channelled by old age fund at the end was quite generous for very frail persons. The new reform was made at constant cost and involved no minimum benefit. The maximum is set in each département by the president of the local assembly, with the maximum ceiling at the national level. There are deep inequalities between departments at the regional level today, as it was the case before. Principles that guided the compensating benefit; means testing and recovery of heavy estate are still there in PSD and middle class who were in trouble are not better off due to the means testing.

181. The risk of geographical inequities is very high as there is no minimum benefit. The president of each local assembly fixes the maximum awarded by each department. There are high inequalities between departments. This point raised a lot of concern in the public debate. Some départements were giving the compensating allocation on a very low level and do the same with the PSD. These huge inequalities create a problem of distributive justice but they are linked with the problems of balancing fiscal resources along départements with different demographic problems. There are older departments with lower resources and richer urban departments with less older persons.

\section{Socio-Economic and Demographic Changes}

182. Population is ageing in France as elsewhere. Longevity and low fertility rates mean that the proportion of people over 65 and 80 years old will rise at a pace parallel with Germany, but slower than in Japan. This increase will be accompanied by a growing number of very frail elderly people with multiple care needs. In the same period the number of potential carers will steadily shrink. The old age dependency ratio will increase from $24 \%$ in 2000 to $32 \%$ in 2020. Women's participation in the labour force between the ages of 25 to 54 years increased from 60-65\% to $80 \%$ between 1980 and 1998. (See chart). 
183. These are factors that reduce actual and future informal care resources, or at least increase the opportunity cost of unpaid work. On the other hand, the majority of those in need of long-term care are cared for at home mainly by close family members.

\section{Germany}

\section{Description of developments in the Policy Regime}

\section{The Bismarkian Model of old age welfare system}

184. The German welfare system is based on corporative independent insurance associations with employers and employees sharing the costs and decision making process. However, it is also strongly state regulated, with most provision determined at the federal level. Apart from this insurance-based scheme, some parts of the welfare system are directly run by the state. For example, the risk of long-term care was mainly covered by the means-tested social assistance scheme, which provided benefits as a last resort. Under this previous scheme, those below the threshold were obliged to turn first to their children for some financial support. Adults in need of long-term care have had to pay privately for services, if their incomes exceeded the social assistance threshold. This created strong restriction to access.

185. In 1992, prior to the introduction of the Care Insurance, 90 per cent of care at home was provided by family members (spouses, daughters and daughters-in-law) and to a lesser extent, by other relatives, friends or neighbours. Those in need of care could also try - via a doctor - to be defined as ill, preferably with a curable illness, in order to have care services covered by the (non-means-tested) health insurance.

186. A strict divide existed between acute health care paid by health insurance, and publicly provided social care paid for by the elderly or in cases of lacking resources, by social assistance. This divide resulted from the origins of health insurance, which had focused on employable workers' acute illness, and from the specific logic of social insurance based claims that have been treated as a right regardless of income and amount of contribution. Bad health was considered in the setting of health insurance as an acute health event: 'Illness' has been traditionally defined as a condition, which can be restored in due time into one of health and independence. Thus, if illness took the form of chronic disability, health insurance no longer covered care services. Chronically sick or care dependent individuals had to pay privately for domiciliary services and for institutional care.

\section{Innovating in Social Policy}

187. The financial strain for adults in need of long-term care and for their families increased in respect to institutional care. Monthly costs for institutional care rose to the equivalent of a low range income for those in need of only some help. These costs could easily go up to the equivalent of a middle income for the very frail, at a level which was well above the available average pension, which only 5 per cent of retired men enjoyed in West Germany, and less than 1 per cent in the East. (Bundesministerium für Arbeit, 1998). For women, that amount was even less (Naegele, 1997).

188. Therefore, long-term care was a financial strain on even the more wealthy elderly, and rendered them dependent on welfare benefits (social assistance) and/or their children. Many children have preferred to care for their elderly parents at home, if only to save their parents' and their own money/inheritance. In addition, the growing number of frail elderly people incapable of paying even a small part of the costs of the services they received at home or in institutions drained the budgets of local governments. 
189. By the mid-1990s, care policies had become an important element in welfare state restructuring in Germany as elsewhere). Particularly, there were strong pressures by local governments, which were feeling the pressure under the previous arrangements. Germany decided to create a fifth pillar of social insurance to provide "Long-term Care Insurance" [Soziale Pflegeversicherung] - in 1995. This was quite an innovation, since the basic schemes for social insurance had been settled generally much earlier than in other countries. (pre-existing legislated pillars are: Employment Related Accident Insurance (1883); Health Insurance (1884), Old Age Disability Insurance (1889), Unemployment Insurance (1927)). This also departs from the trends in other areas of the Welfare State, as the general tightening of eligibility rules for social entitlements attached to paid work has been paralleled by positive state intervention in respect to unpaid care. In this process, legislation seemingly shifted the balance from unpaid care to a new mix of paid and unpaid, formal and informal care, with better recognition for the latter. This was done in spite of strong public financial pressures, resulting from both reunification and the need to match the European Monetary Union criteria.

190. The new care policies indicate shifts in the welfare triangle of market, state, the family and its members. For many observers, the Care Insurance is a step towards a 'leaner' social insurance, and a catalyst in the EU-wide process towards leaner welfare states.

\section{Socio-economic and Demographic Changes}

191. Due to both longevity and low fertility rates the proportion of people older than 75 will rise from seven percent today to more than ten per cent in 2020. This increase will be accompanied by a growing number of very frail elderly people with multiple care needs. In the same period the number of potential carers will steadily shrink. While the ratio of adults of workable age (between the ages of twenty to sixtyfive) and those older than sixty-five was 4 to 1 in 1995, it will change to only 3 to 1 in 2020.

192. Trends in longevity have coincided with changes in family structure. The German fertility rate is very low; couples split more often and female employment rates have steadily grown. Women's participation in the labour force between the ages of 20-59 has increased from about 57\% in 1980 to $72 \%$ in 1998 (see chart).

193. These are factors that reduce actual and future informal care resources, or at least increase the opportunity cost of unpaid work. On the other hand, the vast majority of those in need of long-term care (76 per cent) are still cared for at home mainly by close family members. This was traditionally the case in former East Germany as well. Only one third of those cared for at home receive professional services. Seventy three per cent of informal main carers are women in their fifties and early sixties, and 45 per cent of informal carers aged 16-64 are employed. Care at home and by informal carers is very important in both East and West Germany. In this context, the Care Insurance has been constituted to give a special incentive to home care, with an official acknowledgement for informal community care. 
Japan

\title{
Description of developments in the Policy Regime
}

\author{
The Japanese old age welfare system
}

194. Japan faces a very strong ageing process, much faster than in any other country's record. Traditionally, most long-term care in Japan was provided in the family: over 50\% of the individuals that are aged 65 and older, are living with their offspring. This ratio is much higher than in other developed countries. This is a reflection of Japanese traditional cultural norms. This is also the case in the Southern European countries, but to a lesser extend. In Japan, "living with a child" means predominantly "living with son's family": currently, 83 percent of elderly people live with their sons', mostly first sons' families while 17 percent live with their daughters' families. This is particularly true in rural areas where people live with a family with "the same family name".

\section{Consolidating Social Policy to address the ageing challenge}

195. As a result of demographic changes and increasing urbanisation, demand for elderly care services has increased, leading to a shift in the social structure. In 1989, Japan enacted the Gold Plan to meet the caring needs of a rapidly ageing population. The Gold Plan for elderly care was established to increase social services for elderly. This aimed at facilitating access, shifting away from a social assistance perception and also the perception that such care was to be provided by the family only. This ten-year plan was framed at the national level and implemented at the municipal level. It aimed to increase homehelpers from 31,405 in 1989 to 100,000 in 2000, the numbers of day services from 1,080 centres to 10,000 centres. It provided daytime care for the elderly and increased short-term stay to 50,000 beds. It called for in-home welfare services by establishing non-profit organisation in all municipals. It aimed to develop long-term care facilities to a level of 240,000 beds in special nursing homes, 280,000 beds in health care facilities for the elderly, and 100,000 places in care houses.

\section{Shift from "Social Hospitalisation" to an open nursing Care}

196. About half of the elderly being given care are being nursed in hospitals. Many elderly patients are being cared for not only in hospitals for elderly persons, but even in general hospitals. The so-called "social hospitalisation" of elderly persons -- subsidised hospitalisation of elderly people on the long run due to social reasons such as the lack of care-givers at home combined with biased economic incentives rather than medical necessity-- has been pointed out to be a problem for the medical insurance system. On the other hand, more than one million elderly persons who are being taken care of at home, are in need of nursing care as they suffer very severe disability, such as being bedridden, or cognitive impairments such as senile dementia, etc. It appears highly desirable both for efficiency and welfare reasons, to gradually shift care from medical institutions to special nursing homes. One of the goals of the Japanese social policy in this field is to facilitate such a shift.

\section{Socio-Economic and Demographic Changes}

197. It has been traditionally the case that elderly parents live with their (eldest) son's family, with an arrangement for sharing resources. When care is provided by family members, an overwhelming majority 
of carers are women representing 85 percent of all carers. According to Japan's largest trade union confederation, RENGO, over 100,000 workers resign from work every year due to "family care", an overwhelming majority of whom are women.

198. The current Constitution of Japan guarantees formal equality between genders, husbands and wives, and the Civil Code also includes gender equality. Social economic changes led to an increase in female employment. Female participation in the labour force between the ages of 20-59, has increased from $58 \%$ in 1980 to $67 \%$ in 1999 (see chart).

199. The change in the population structure caused by low fertility and ageing, coupled with increases in female employment, and changes in the economy due to increases in general employment have interactively changed the traditional family structure. The household structure has been reduced from the conventional large family with three and more generations to two or less generations with a smaller number of members.

\section{Description of Benefits}

\section{The process towards Public Long-term Care Insurance Scheme and Cash Benefit}

200. As a result of ever-increasing medical expenses for "social hospitalisation" and other services for the elderly, a new system of welfare services has been under discussion to secure financial sources to cover the mounting costs of care for the elderly. The system is the Public Long-term Care Insurance Scheme. Under this system, people will be obliged to pay for a new premium. The amount of the premium is under consideration. It is likely to be about 3,000 yen per month to be collected from every person at the age of 40 and over as of April 2000 when the scheme is put into force.

201. Due to the recent economic slowdown, there is a concern for the potential implications of such a scheme for the public finances. The Gold Plan introduced in 1989 can be considered to be a precondition to introduce the Long-term Care Insurance scheme. The effective implementation of a public long-term care scheme has taken some time after the law was promulgated in December 1997 and it should now begin in 2000 .

\section{Developments after the Enactment of Public Long-term Care Insurance Act}

202. The current long-term care insurance act stipulates that services will be provided in kind, and will be channelled through local governments. The representatives of local governments had insisted on the need of cash benefits before the enactment of the Long-term Care Insurance Act. At the Public Hearing held at various locations, representatives of local governments spoke in favour of providing cash benefits. "After the enactment of the Act, local assemblies voiced their requests that the provision of cash benefits be reconsidered "considering the reality in the rural areas."

203. An Advisory Council had been established to discuss the details for implementing the care insurance. The possibility of "Care services by Community participation" was evoked, in its discussions with a benefit directly paid to nursing care-givers, without a care service plan set by a third person. In this scheme informal care-givers would be given more recognition and training. This new cash benefit proposal differs from the previous proposal under which benefits were given to the insured elderly in need of care. Under the new proposal care-giving family members are to be paid, provided that they are recognised as family helpers. With this, an apprehension expressed by those against cash benefits, that the 
money given to the needy elderly might be taken by their family members and not given to their son's wives taking the burden of caring, has been cleared.

\section{Mechanism to Receive Services under the Long-term Care Insurance Scheme due to begin in 2000}

204. The Long-term Care Insurance Scheme will not in principle provide cash benefits, in spite of the strong pressure to recognise family helpers and remunerate them in cash (as an exceptional measure in remote districts). The insured people under the scheme are classified into Category 1 (people aged 65 and over) and Category 2 (people aged between 40 and 64), both of whom are required to pay premiums. The category 1 beneficiaries are insured, when they need care or support. Those belonging to category 2 are insured when they suffer from specified age-induced diseases such as dementia and cerebro-vascular disorder. When a person becomes needy of care or support, she/he is able to apply for recognition as a needy person.

- Application can be submitted by the elderly, family, care management agency, and assigned care providing institutions.

- Applicants are visited by trained municipal employees and care managers, who assess the financial situation of the applicants. The results will be processed, screened and submitted to a Jury comprising health, medical and welfare personnel. The criteria to determine eligibility include both mental and physical conditions of the applicants, and social and economic criteria.

- There is a $10 \%$ co-payment rate in the benefits received on every service fee.

205. The basic concept of the Care Insurance scheme is to help the elderly help themselves. Older persons' own desires are respected, and every service they receive should be decided based upon their desires and with their consent. For those who have dementia, family members' desires will be reflected. In addition, a bill to establish an Adult Guardian System is currently prepared revising the relevant laws in the Civil Code to be finished in time for the start of the Care Insurance scheme. Intervention in the property management and monitoring of the life to safeguard the well being and desire of elderly people in need of care by a public or a third-party organisation is now being organised at the municipal level.

206. Unlike the present welfare system whereby the authority decides what service should be applied to a beneficiary, users can select what kind of care services they would like to combine within the amount of service benefits and accordingly conclude a contract with a service provider. A care manager functions as a liaison officer between users and the municipality, accommodation service operators, institution operators, various service providers, and prepares a care-service plan for each user reflecting his/her desires and needs. 


\section{LABOUR MARKET AND SOCIAL POLICY OCCASIONAL PAPERS}

Most recent releases are:

No.40 PHARMACEUTICAL POLICIES IN OECD COUNTRIES: RECONCILING SOCIAL AND INDUSTRIAL GOALS (2000) Stephane Jacobzone

No. 39 NET SOCIAL EXPENDITURE (1999) Willem Adema

No. 38 AGEING AND CARE FOR FRAIL ELDERLY PERSONS: AN OVERVIEW OF INTERNATIONAL PERSPECTIVES (1999) Stéphane Jacobzone

No. 37 THE HEALTH OF OLDER PERSONS IN OECD COUNTRIES: IS IT IMPROVING FAST ENOUGH TO COMPENSATE FOR POPULATION AGEING? (1998) S. Jacobzone, E. Cambois, E. Chaplain, J.M. Robine

No. 36 HEALTH OUTCOMES IN OECD COUNTRIES: A FRAMEWORK OF HEALTH INDICATORS FOR OUTCOME-ORIENTED POLICYMAKING (1998) Melissa Jee and Zeynep Or

No. 35 WHAT WORKS AMONG ACTIVE LABOUR MARKET POLICIES: EVIDENCE FROM OECD COUNTRIES' EXPERIENCES (1998) John Martin

No. 34 MEASURES OF JOB SATISFACTION - WHAT MAKES A GOOD JOB? EVIDENCE FROM OECD COUNTRIES (1998) Andrew E. Clark (available in French)

No. 33 SOCIAL AND HEALTH POLICIES IN OECD COUNTRIES: A SURVEY OF CURRENT PROGRAMMES AND RECENT DEVELOPMENTS [Text and Annex] (1998) D.W. Kalisch, T. Aman and L. A. Buchele

No. 32 THE GROWING ROLE OF PRIVATE SOCIAL BENEFITS (1998) Willem Adema and Marcel Einerhand

No. 31 KEY EMPLOYMENT POLICY CHALLENGES FACED BY OECD COUNTRIES (1998) OECD SUBMISSION TO THE G8 GROWTH, EMPLOYABILITY AND INCLUSION CONFERENCE - London, 2122 February 1998

No. 30 PRIVATE PENSIONS IN OECD COUNTRIES - FRANCE (1997) Emmanuel Reynaud (available in French)

No. 29 OECD SUBMISSION TO THE UK LOW PAY MISSION (1997)

No. 28 OECD SUBMISSION TO THE IRISH NATIONAL MINIMUM WAGE COMMISSION (1997)

A complete list of available papers can be found on the internet site: http://www.oecd.org/els/papers/papers.htm, through which recent papers can be accessed directly. To receive a paper copy of this list or any particular papers, please send your name, organisation and full address to:

Labour Market and Social Policy Occasional Papers

Directorate for Education, Employment, Labour and Social Affairs

OECD, 2, rue André-Pascal, 75775 PARIS CEDEX 16, FRANCE

Mailing List for free of charge Labour Market and Social Policy Occasional Papers

Please include the following name on the mailing list:

(write in capitals)

Name

Organisation

Address 


\section{RECENT OECD PUBLICATIONS IN THIS FIELD INCLUDE:}

\section{"OECD SOCIAL POLICY STUDIES" SERIES}

No. 21 FAMILY, MARKET AND COMMUNITY: EQUITY AND EFFICIENCY IN SOCIAL POLICY (1997)

No. 20 AGEING IN OECD COUNTRIES: A CRITICAL POLICY CHALLENGE (1996)

\section{MISCELLANEOUS}

A SYSTEM OF HEALTH ACCOUNTS (2000)

OECD ECONOMIC STUDIES No. 31, 2000/2 (Special issue on “Making Work Pay") (2000)

POLICIES TOWARDS FULL EMPLOYMENT (OECD Proceedings) (2000)

LABOUR MIGRATION AND THE RECENT FINANCIAL CRISIS IN ASIA:

(OECD Conference Proceedings) (2000)

OECD SOCIAL EXPENDITURE DATABASE, 1980-1996 (1999)

available in English and French on CD-ROM

OECD HEALTH DATA (1999)

available in English, French, Spanish and German on CD-ROM (Windows 95, 98 or NT)

A CARING WORLD - The New Social Policy Agenda (1999)

MAINTAINING PROSPERITY IN AN AGEING SOCIETY (1998)

THE BATTLE AGAINST EXCLUSION - Volume 3

Social Assistance in Canada and Switzerland (1999)

THE BATTLE AGAINST EXCLUSION - Volume 2

Social Assistance in Belgium, the Czech Republic, the Netherlands and Norway (1998)

THE BATTLE AGAINST EXCLUSION

Social Assistance in Australia, Finland, Sweden and the United Kingdom (1998)

OECD EMPLOYMENT OUTLOOK June 1999 (published annually)

THE PUBLIC EMPLOYMENT SERVICE IN THE UNITED STATES (1999)

BENEFIT SYSTEMS AND WORK INCENTIVES (1999)

THE FUTURE OF FEMALE-DOMINATED OCCUPATION (1998)

For a full list, consult the OECD On-Line Bookstore on: http://www.oecd.org or write for a free written catalogue to the following address:

OECD Publications Service

2, rue André-Pascal, 75775 PARIS CEDEX 16

or to the OECD Distributor in your country 